Portland State University

PDXScholar

12-20-1971

\title{
Adsorption of Sulfur Dioxide on Douglas Fir Woodchips
}

Uen-Ping David Wang

Portland State University

Follow this and additional works at: https://pdxscholar.library.pdx.edu/open_access_etds

Part of the Atmospheric Sciences Commons, and the Environmental Monitoring Commons Let us know how access to this document benefits you.

Recommended Citation

Wang, Uen-Ping David, "Adsorption of Sulfur Dioxide on Douglas Fir Woodchips" (1971). Dissertations and Theses. Paper 1559.

https://doi.org/10.15760/etd.1558

This Thesis is brought to you for free and open access. It has been accepted for inclusion in Dissertations and Theses by an authorized administrator of PDXScholar. Please contact us if we can make this document more accessible: pdxscholar@pdx.edu. 
AN ABSTRACT OF THE THESIS OF Uen-ping David Wang for the Master of

Sclence in Applied Sclence presented December 20, 1971

Title: Adsorption of Sulfur Dioxide on Douglas Fir Woodchips

APPROVED BY MEMBERS OF THE THESIS COMMTTTEE:

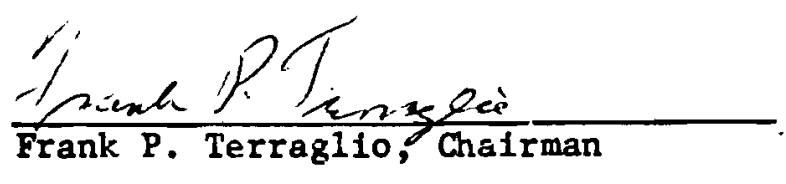

$$
\text { N... T.C / te... }
$$

Nan-Teh Hsu
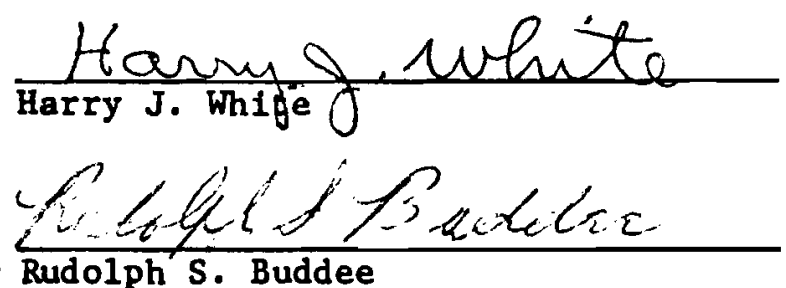

In recent years, people have raised their alertness to the hazard of alr pollution. Sulfur dloxide is one of the most dangerous chemical. compounds among those alr pollutants. A study on removing sulfur dioxide from an alr stream by adsorption using woodchips as the adsorbent is presented in this thesis.

The reason for using wood as an adsorbent is that wood is a porous material and possesses a large surface of cell cavitles which can hold a great amount of molsture. As sulfur dioxide gas is passed through the wood bed, it would be elther condensed in the cell space of the wood by Intermolecular attraction, adsorption or dissolved in the molsture held in the wood.

This work was started with a review of literature. Then related 
references were collected and a proposal written. Douglas fir was chosen for the experiment because it is the most common kind of wood in the Pacific Northwest. After the process and proper equipment was set up, woodchips were screened and dried to prepare for further experiments. It was decided to use three different concentrations of sulfur dioxide. For each of the concentrations of sulfur dioxide, five levels of molsture (0\%, $11 \%, 20 \%$, $50 \%$ and saturated) were assigned to the selected woodchips. Fifteen combinations or experiments were done for the research.

The results of the experiments show that dry wood ( $0 \%$ molsture content) had comparatively low characteristics in the adsorption of sulfur dioxide. For inṣtance, at an influent $\mathrm{SO}_{2}$ concentration of $1.12 \mathrm{ppm}$. , about 6 grams of dry woodchips adsorbed $29.37 \mathrm{\mu g}$. of sulfur dioxide in comparison to $2090.5 \mu g$. of $\mathrm{SO}_{2}$ adsorbed in the same weight of woodchips but saturated with moisture. At an influent $\mathrm{SO}_{2}$ concentration of $1.83 \mathrm{ppm}$., the adsorp: tion of sulfur dioxide increased from $7.73 \mu \mathrm{g}$. for the dry wood to 745.15 48. In the water saturated wood. For an influent $\mathrm{SO}_{2}$ concentration of 4.60 ppm., dry wood adsorbed $15.26 \mu \mathrm{g}$. of $\mathrm{SO}_{2}$ while the molsture saturated wood adsorbed $1446.2 \mathrm{\mu g}$. The amount of dry woodchips used in above mentioned experiments were all about 6 grams. These data show that the moisture. saturated wood adsorbed about 90 times the amount of sulfur dioxide that the dry wood adsorbed. It is clear that, the wood adsorptivity increased with Increasing moisture content. It was also found that wood adsorptivity and retention time were affected by the different flowrate of carrier gas. The figures show that most of the data fit a Freundlich equation. Other equations were developed to calculate the adsorptivity and retention time by obtalning the influent and effluent concentration of sulfur dioxide through the adsorbent bed. 
ADSORPTION OF SULFUR DIOXIDE

ON

DOUGLAS FIR WOODCHIPS

by

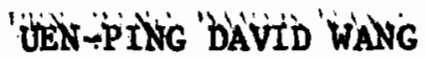

A thesis submitted in partial fulfillment of the requirements for the degree of

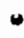

In

APPLIED SCIENCE

Portland State Untversity

1971 
TO THE OFFICE OF GRADUATE STUDIES:

The members of the Comittee approve the thesis of Uen-ping David Wang presented December 20, 1971

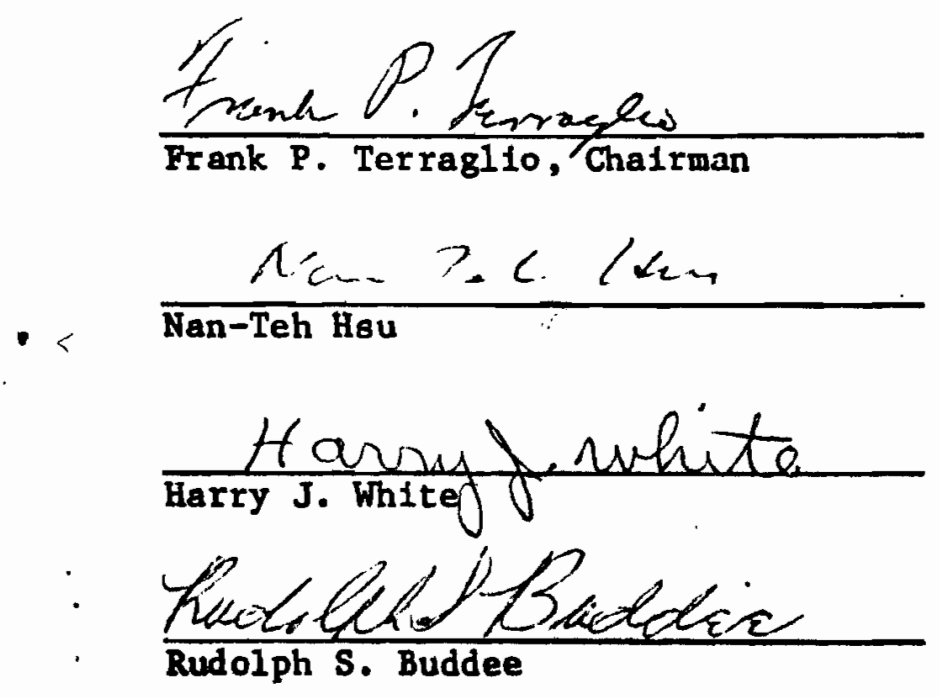

APPROVED:

Alain 72.2 lates

Nan-Teh Hsy, Head, Department of Applied Science

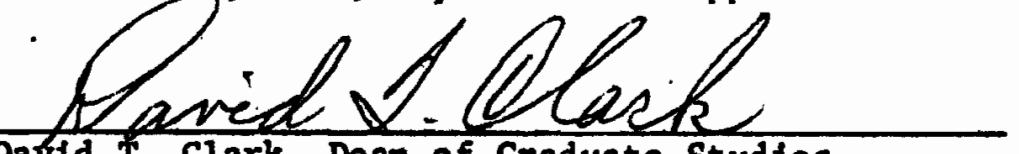

Dafid T. Clark, Dean of Graduate Studies 
TABLE OF CONTENTS.

PAGE

ACKNOWLEDGMENT . . . . . . . . . . . . . . . . 111

LIST OF TABLES ... . . . . . . . . . . . . . . v v

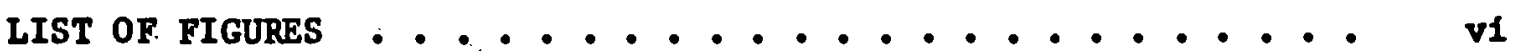

LIST OF APPENDICES . . . . . . . . . . . . . . v111

CHAPTER

I INTRODUCTION . . . . . . . . . . . . . 1

.$- \quad$ II LITERATURES REVIEW . . . . ............ 5

III THE PROCESS OF SORPTION . . . . . . . . . . 11

IV EXPERIMENTAL PROCEDURES . . . . . . . . . . 21

V EXPERIMENTAL RESULTS . . . . . . . . . . . 33

vI DISCUSSION . . . . . .............. 64

VII SUMAARY AND CONCLUSION . . . . . . . . . . 69

BIBLIOGRAPHY . . . . . . . . . . . . . . . . . 72

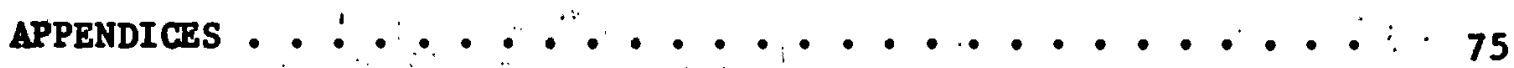


As $I$ come around the last corner of my advanced studies at Portland State University, the list of professors to whom thanks should be extended is very long. I was fortunate to have as my thesis professor and chief advisor, a chemist, Dr. Frank P. Terraglio, with whom I spent much time and effort in the laboratory. I am indebted to Dr. Terraglio for providing encouragement and numerous helpful comments throughout all phases of my research work. Sincerest thanks also go to Dr. Harry J. White for serving on the thesis committee and offering precious information. During the past year, his instruction In "Systems Analysis and Synthesis" helped to pave the way for the research experiments. Special appreciation and thanks go to Dr. Nan-Teh Hsu, who served and advised on my thesis commfttee and has contributed so many suggestions and assistance with my research. To many of my friends, especialiy Robert B. Percy goes to credit for the assistance in preparing some equipment and information. I also wish to thank Donna Mikulic for her invaluable help in typing this thesis.

- There are no words to express my gratitude to my parents. I only hope that this effort will compensate for their deprivation, patience, and endless love.

This thesis is dedicated to my parents. 


\section{LIST OF TABLES}

TABLE

PAGE

I Atmospheric Sulfur Dioxide Emissions In 1963 and 1966 by Sources In the UnIted States........ 3

II Sulfur Dloxide Emissions in the State of.Oregon in 1968 . . . . . . . . . . . . . 4

III Comparison of Physical Adsorption and Chemlsorption . . - 14

IV Some Physical Properties of Douglas FIr . . . . . . . 28

v Some Chemical Propertles of Douglas F1r . . . . . . . 30

VI Adsorption Efficiencles and Adsorptivity of Wood for an Influent $\mathrm{SO}_{2}$ Concentration of $1.12 \mathrm{ppm} . . . . . .55$

VII Adsorption Efficlencles and Adsorptivity of Wood for an Influent $\mathrm{SO}_{2}$ Concentration of $1.83 \mathrm{ppm}$. . . . . 56

VII Adsorption Efficlencles and Adsorptivity of Wood for an Influent $\mathrm{SO}_{2}$ Concentration of $4.60 \mathrm{ppm}$. . . . . 57

IX List of the Values of the Constants " $\mathrm{K}$ " and " $\mathrm{n}$ " In

Freundlich Equation for the Adsorption of

Sulfur Bloxide on Douglas F1r Woodchlps . . . . 60 
LIST OF FI GURES

PIGURE

PAGE

1. The Absorption of Sulfur Dioxide Solution (5\%) by

Sprucewood .................... 6

2. Sulfonation of Spruce Groundwood with 2, 5 and $10 \%$

Solution at Room Temperature . . . . . . . 8

3. Sulfonation of Hemlock Protolignin with $10 \% \mathrm{SO}_{2}$

Solution at Room Temperature ...... . . . . 9

4. The Typical Example of Adsorption Isotherms. . . . . 13

5. Types of Adsorption. Isotherms . . . . . . . . . 16 。

6. Flow Diagram for the Adsorption of Sulfur Dioxide

on Douglas Fir Woodchips............ 22

7. $\mathrm{SO}_{2}$ Distribution Apparatus . . . . . . . . . 23

8. $\mathrm{SO}_{2}$ Nominal Permeation Rates for "Dynacal" Tubes . . . 25

9. The Adsorption of $\mathrm{SO}_{2}$ on Dry Wood at an Influent $\mathrm{SO}_{2}$ Concentration of $1.12 \mathrm{ppm}$. . . . . . . . . 34

10. The Adsorption of $\mathrm{SO}_{2}$ on Wood with $11 \% \mathrm{H}_{2} \mathrm{O}$ at an Influent $\mathrm{SO}_{2}$ Concentration of $1.12 \mathrm{ppm}$. . . . . 35

11. The Adsorption of $\mathrm{SO}_{2}$ on Wood with $20 \% \mathrm{H}_{2} \mathrm{O}$ at an Influent $\mathrm{SO}_{2}$ Concentration of $1.12 \mathrm{ppm}$. . . . . . 36

12. The Adsopption of $\mathrm{SO}_{2}$ on Wood with $50 \% \mathrm{H}_{2} \mathrm{O}$ at an Influent $\mathrm{SO}_{2}$ Concentration of $1.12 \mathrm{ppm}$. . . . . 37

13. The Adsorption of $\mathrm{SO}_{2}$ on Wood with saturated molsture at an Influent $\mathrm{SO}_{2}$ Concentration of $1.12 \mathrm{ppm}$. . . 38

14. The Adsorption of $\mathrm{SO}_{2}$ on Dry Wood at an Influent $\mathrm{SO}_{2}$ Concentration of $1.83 \mathrm{ppm}$. . . . . . . . . 40

15. The Adsorption of $\mathrm{SO}_{2}$ on Wood with $11 \% \mathrm{H}_{2} \mathrm{O}$ at an Influent $\mathrm{SO}_{2}$ Concentration of $1.83 \mathrm{ppm}$. ...... 41

16. The Adsorption of $\mathrm{SO}_{2}$ on Wood with $20 \% \mathrm{H}_{2} \mathrm{O}$ at an Influent $\mathrm{SO}_{2}$ Concentration of $1.83 \mathrm{ppm}$. . . . . . 42

17. The Adsorption of $\mathrm{SO}_{2}$ on Wood with $50 \mathrm{~K} \mathrm{H}_{2} \mathrm{O}$ at an Influent $\mathrm{SO}_{2}$ Concentration of $1.83 \mathrm{ppm}$. . . . . 
18. The Adsorption of $\mathrm{SO}_{2}$ on Wood with Saturated Molsture at an Influent $\mathrm{SO}_{2}$ Concentration of $1.83 \mathrm{ppm}$. . .

19. The Adsorption of $\mathrm{SO}_{2}$ on Dry Wood at an Influent $\mathrm{SO}_{2}$ Concentration of $4.60 \mathrm{ppm}$. . . . . . . .

20. The Adsorption of $\mathrm{SO}_{2}$ on Wood with $11 \% \mathrm{H}_{2} \mathrm{O}$ at an Influent $\mathrm{SO}_{2}$ Concentration of $4.60 \mathrm{ppm}$. . . . . 46

21. The Adsorption of $\mathrm{SO}_{2}$ on Wood with $20 \% \mathrm{H}_{2} \mathrm{O}$ at an Influent $\mathrm{SO}_{2}$ Concentration of $4.60 \mathrm{ppm}$. .....

22. The Adsorption of $\mathrm{SO}_{2}$ on Wood with $50 \% \mathrm{H}_{2} \mathrm{O}$ at an Influent $\mathrm{SO}_{2}$ Concentration of $4.60 \mathrm{ppm}$. .....

23. The Adsorption of $\mathrm{SO}_{2}$ on Wood with Saturated Moisture at an Influent $\mathrm{SO}_{2}$ Concentration of $4.60 \mathrm{ppm}$. ...

24. Comparison of the Saturation Rate of Sulfur Dioxide on Dry Wood at Different Influent $\mathrm{SO}_{2}$ Concentrations. .

25. Adsorption of $\mathrm{SO}_{2}$ by Douglas Fir Woodchips in Different Molsture Content at an Influent $\mathrm{SO}_{2}$ Concentration of $1.12 \mathrm{ppm} . . . . . . . . .{ }^{2}$. . . . . .

26. Adsorption of $\mathrm{SO}_{2}$ by Douglas Fir Woodchips in Different Moisture Content at an Influent $\mathrm{SO}_{2}$ Concentration of $1.83 \mathrm{ppm} . . . . . . . . . . . . . . .$.

27. Adsorption of $\mathrm{SO}_{2}$ by Douglas Fir Woodchips in Different Molsture Content at an Influent $\mathrm{SO}_{2}$ Concentration of $4.60 \mathrm{ppm}$. ..................

28. Influence of Moisture on the Adsorption of $\mathrm{SO}_{2}$ by Woodchips at the Different Influent $\mathrm{SO}_{2}$ Concentrations ................

29. Freundlich Adsorption Isotherm for Sulfur Dioxide on Wood for an Influent $\mathrm{SO}_{2}$ Concentration of $1.12 \mathrm{ppm}$. . •

30. Freundlich Adsorption Isotherm for Sulfur Dioxide on Wood for an Influent $\mathrm{SO}_{2}$ Concentration of $1.83 \mathrm{ppm}$. . .

31. Freundilch Adsorption Isotherm for Sulfur Dioxide on Wood for an Influent $\mathrm{SO}_{2}$ Concentration of $\$ 4.60 \mathrm{ppm}$. . . 


\section{LIST OF APPENDICES}

APPENDIX

PAGE

I Solub1lity of Sulfur Dloxide In Water . . . . . . . 76

II Estimation of Adsorber Dlameter . . . . . . . . . 77

III Determination of Sulfur DIoxide by West and

Gaeke Method . . . . . . . . . ... . . 78

1. Calculation of Cumulative Amount of $\mathrm{SO}_{2}$ on Dry Wood for an Influent $\mathrm{SO}_{2}$ Concentration of $1.12 \mathrm{ppm}$. . . $82 \mathrm{~b}$

2. Calculation of Cumulative Amount of $\mathrm{SO}_{2}$ on Wood with $117 \mathrm{H}_{2} \mathrm{O}$ for an Influent $\mathrm{SO}_{2}$ Concentration of

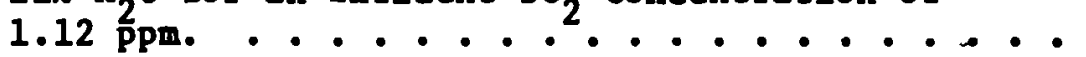

3. Calculation of Cumulative Amount of $\mathrm{SO}_{2}$ on Wood with $20 \% \mathrm{H}_{2} \mathrm{l}$ for an Influent $\mathrm{SO}_{2}$ Concentration of $1.12 \mathrm{ppm}, . . . . . .2$.......... 84

4. Calculation of Cumulative Amount of $\mathrm{SO}_{2}$ on Wood with $50 \% \mathrm{H}_{2} \mathrm{O}$ for an Influent $\mathrm{SO}_{2}$ Concentration of 1.12 ppm. . . . . . . . . . . . . . .

5. Calculation of Cumulative Amount of $\mathrm{SO}_{2}$ on Wood with saturated Molsture for an Influent $\mathrm{SO}_{2}$ Concentration of $1.12 \mathrm{ppm}$. . ... . . . . . 86

6. Calculation of Cumulative Amount of $\mathrm{SO}_{2}$ on Dry Wood for an Influent $\mathrm{SO}_{2}$ Concentration of $1.83 \mathrm{ppm}$. . .

7. Calculation of Cumulative Amaunt of $\mathrm{SO}_{2}$ on Wood with $11 \% \mathrm{H}_{2} \mathrm{O}$ for an Influent $\mathrm{SO}_{2}$ Concentration of 1.83 .

8. Calculation of Cumulative Amount of $\mathrm{SO}_{2}$ on Wood with $20 \% \mathrm{H}_{2} \mathrm{O}$ for an Influent $\mathrm{SO}_{2}$ Concentration of ", $1.83 \mathrm{ppm}$. 
9. Calculation of Cumulative Amount of $\mathrm{SO}_{2}$ on Wood with $50 \% \mathrm{H}_{2} \mathrm{O}$ for an Influent $\mathrm{SO}_{2}$ Concentration of $1.83 \mathrm{ppm}$. . . . . . . . . . . . . . 9 90

10. Calculation of Cumulative Amount of $\mathrm{SO}_{2}$ on Wood with Saturated Molsture for an Influent $\mathrm{SO}_{2}$ Concentration of $1.83 \mathrm{ppm}$. .... . . . . . 91

11. Calculation of Cumulative Amount of $\mathrm{SO}_{2}$ on Dry Wood for an Influent $\mathrm{SO}_{2}$ Concentration of $4.60 \mathrm{ppm}$. . . . 92

12. Calculation of Cumulative Amount of $\mathrm{SO}_{2}$ on Wood with $11 \% \mathrm{H}_{2}^{2} \mathrm{O}$ for an Influent $\mathrm{SO}_{2}^{\circ}$ Concentration of

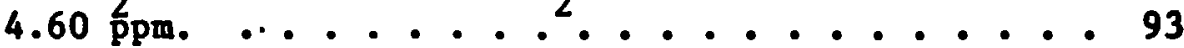

13. Calculation of CumulativeeAmount of $\mathrm{SO}_{2}$ on Wood with $20 \% \mathrm{H}_{2} \mathrm{O}$ for an Influent $\mathrm{SO}_{2}$ Concentration of 4.60 ppm. . . . . . . . . . . . . . 94

14. Calculation of Cumulative Amount of $\mathrm{SO}_{2}$ on Wood with $50 \% \mathrm{H}_{2} \mathrm{O}$ for an Influent $\mathrm{SO}_{2}$ Concentration of

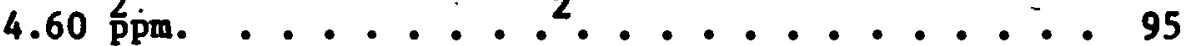

15. Calculation of Cumulative Amount of $\mathrm{SO}_{2}$ on Wood with Saturated Molsture for an Influent $\mathrm{SO}_{2}$ Concentration of $4.60 \mathrm{ppm}$............ 96

APPENDIX

FIGURE

PAEE

1. Calibration Curve in the Analysis of $\mathrm{SO}_{2}$ by West and Gaeke Method 


\section{CHAPTER I}

\section{INTRODUCTION}

In the past century there has been a radical change In man's existence. Improvement in nutrition, agriculture, communication, hyglene, and medicine have extended man's Iffe span tremendously. These Improvements have also increased population density on the earth. ThIs increasing population and longevity, together with a high standard of living and rapld Industrial development now generate a pressure on the environment because of the accompanying Increase in waste products of all sorts. The existence of such products in the atmosphere is the problem which 18 termed "Alr Pollution".

Alr is our most important resource. Of the four fundamental resources of land, fuel, water and air; alr is the most limited in supply and cannot be replaced by other substances. Yet, alr in the Unfted States and the rest of the world is continually being polluted by different sources. It has been reported that the total estimable economic $108 s$ from air pollution In the United States 18 about $\$ 12$ b1l11on per year. $(15,28)$ In Callfornia alone, smog does about $\$ 15$ million of visible damage and $\$ 132$ million of non-visible total damage to the agricultural crops. (35) Before the sun 18 further dimmed, before more flowers wither and die, before more people suffocate in a rank and palsoned world, we must change our ways and learn to live within the laws of nature. We must learn the facts of 11 fe and prevent tts being polluted from its sources. 
Among many contaminants contributing to the pollution, sulfur dioxide 1s one of the most important. Major sources of sulfur dloxide released to the atmosphere are presented in Table I. $(13,27)$ Table II (10) 1s for the State of Oregon in 1968. Damage by sulfur dloxide has been reported in many papers $(14,18,23,30,37)$ and the reduction of sulfur dioxide in the atmosphere 1s desirable. The purpose of this thesis is to study the use of woodchips as an adsorbent to remove sulfur dloxide from a gas stream. Further developments might bring about the recovery of waste woodchips for additlonal industrlal usage. In addition, operating costs in some Industries could be reduced if satisfactory results could be found to recover sulfur dioxide and ways could be found to make use of woodchips. 
TABLE I

ATMSPHERIC SULFUR DIOXIDE EMISSIONS IN 1963 AND

1966 BY SOURCES IN THE UNITED STATES

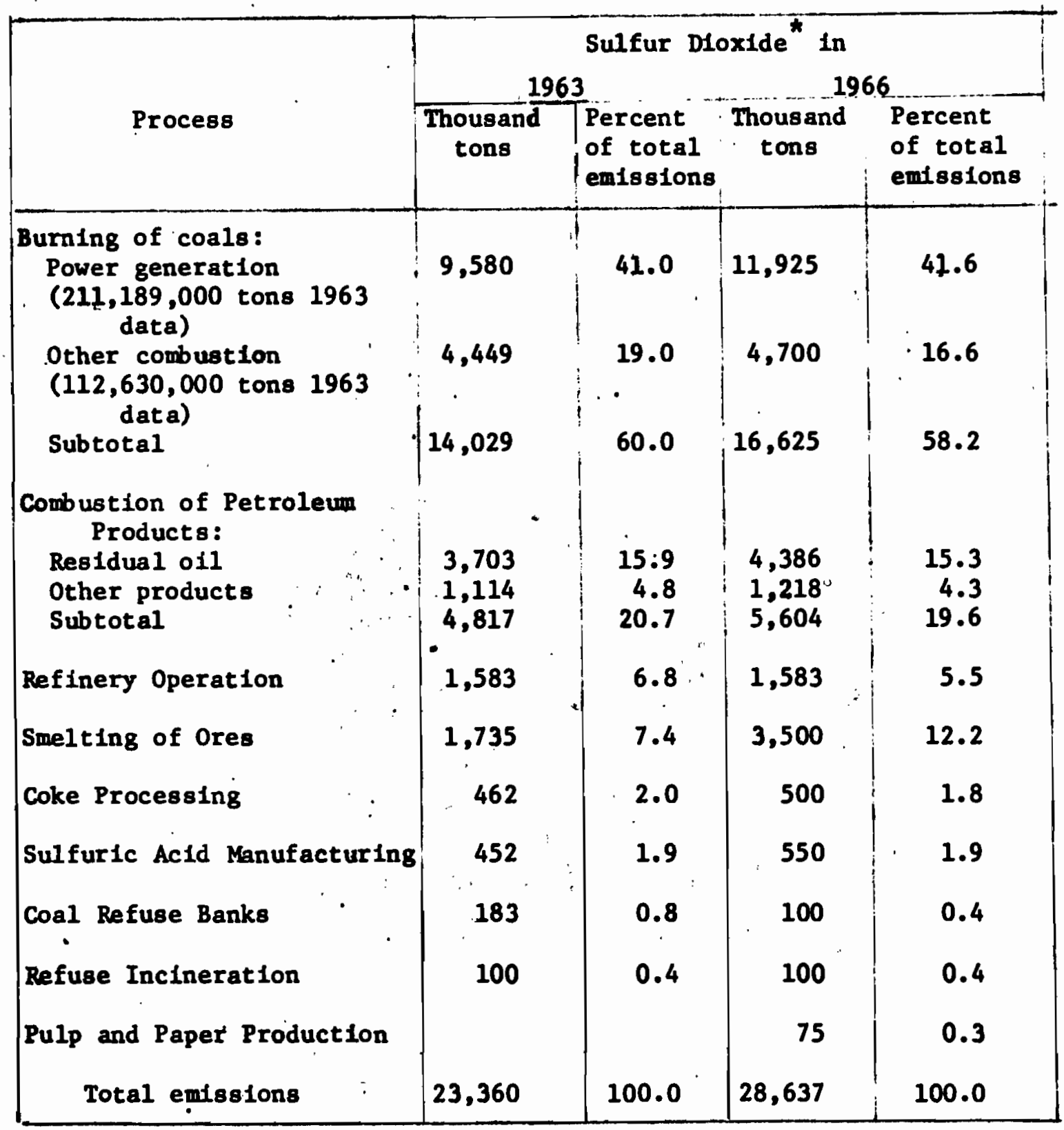

*A small amount of thls tónnage is converted to sulfuric acld wist before discharge to the atmosphere. The rest 18 eventuslly oxidized and/or washed out. Only under unusual meterological conditions does accumulation occur. 
TABLE II

SULFUR DIOXIDE EMISSIONS IN THE STATE OF OREGON IN 1968

\begin{tabular}{cc}
\multicolumn{2}{c}{ Sulfur dioxide } \\
$\begin{array}{c}\text { Thousand tons } \\
\text { per year }\end{array}$ \\
Percent of annual \\
total
\end{tabular}

Mobil Sources Mbtor vehicles

4.54

9.56

Aircraft

0.0

0.0

Ships

0.84

1.77

Subtotal

.5 .38

11.33

Puel Burning

011-Domestic

- Commerctal

4.49

9.47

-Industrial

5.28

11.12

11.37

23.95

Gas-Domestic

0.00

0.00

- Commercial

0.00

0.00

-Industrial

0.01

Wood residual

0.0

0.01

21.15

0.0

Subtotal

$\therefore \quad 0.0$

44.57

Refuse Burning

0.0

Agricultural/Forestry

Fleld burning

0.0

0.0

Slash burning

0.0

0.0

Subtotal

0.0

0.0

4 Wood products

Pulp and Papers

18.89

41.92

Other industries

Metal industry

Asphalt paving

Miscellaneous

Subtotal

1.00

2.11

0.0

0.0

0.04

0.08

1.04

2.19

Total Emissions

47,45

100.00

Hote: Emissions listed as 0.0 indicates source not significant or not considered. Emissions listed as 0.00 indicates gilssions computed but 1 ess than 0.005 . 


\section{CHAPTER II}

\section{LITERATURE REVIEW}

There has been a vast quantity of research literature in the past century reporting the elimination of sulfur dloxide from gas mixtures by using the processes of absorption and adsorption. Solutions of water (29), ammonlum hydroxide (1), manganese oxyhydroxide (1), lime (1), zinc oxide (26), amines and many other chemicals have been used to absorb $\mathrm{SO}_{2}$ by the process of absorption and solid materials such as charcoal (12), silica gel (24), molecule sieve, zeolite (21), anton resins (19), activated alumina, so1ls (31), and many other porous materials were also used as an adsorbent to selectively remove sulfur dloxide from flue gases. The motivation of using wood as an adsorbent was that the wood is one of the porous materials and it had been reported to react with the dilute sulfur dioxide solution readily.

1. One of the major constituent of cell walls in wood 1s 11gnin. The IIgnin content (5) of softwoods ranges from 25 to 35 percent; that of hardwoods 18 usually conslderably lower, varying from 17 to 25 percent. Scientists found that at ordinary temperature the sulfonation of $11 \mathrm{gnin}$ in wood takes places quite read1ly. Brauns and MacLaurin (3) treated extracted sprucewood flour with $5 \%$ of sulfur dloxide solution at room temperature and found that sprucewood combined with sulfurous acld quite rapldly at first (see F1g. 1). In long-term experiments, lasting 16 months, western hemlock chips were treated with a $10 \%$ solution of sulfur dioxide at room temperature. The ambunt of sulfur taken up by the wood, the amount of wood 


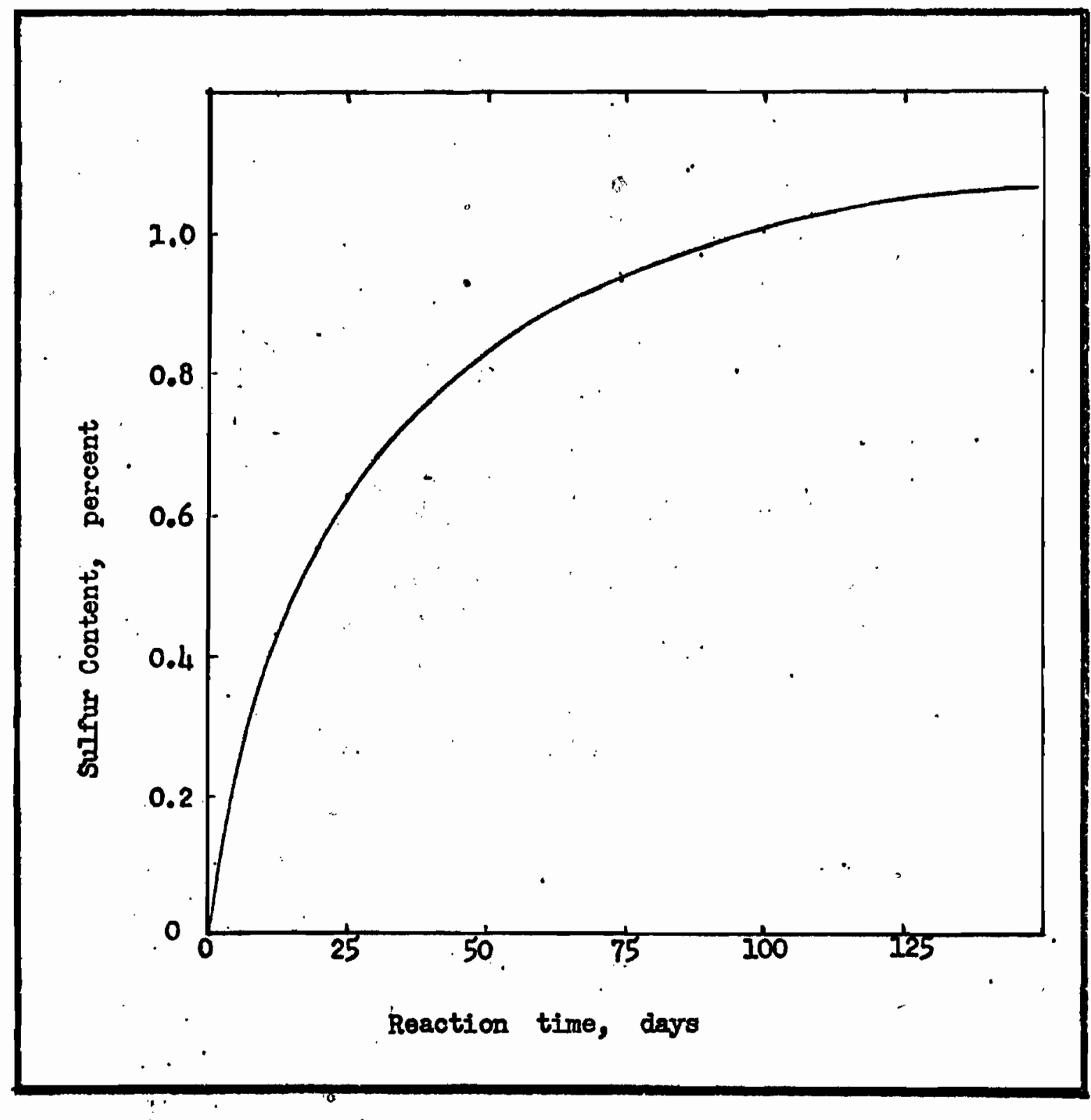

Fig, 1. The absorption of sulfur dioxide solution (5\%) by sprucewood. 
recovered, its lignin content, the amount of lignin dissolved, and the amount of bulfur In the 11gnin are shown In Fig. 2 and Fig. 3. It 18 found that the curve on the absorption of sulfur dioxide in both F1g. 2 and Fig. 3 was Identical with that found in Fig. 1.

2. In analyzing the wood ash, it was found that the mineral matters ranged from about 0.5 to 5 percent, sometimes even higher depending on the different woods. The most abundant metallic oxide component of wood ash 18 calclum oxide (11me), which may comprise one-half to three-fourths of the total. (3) LIme when dissolved in water can readily react with sulfur dioxide to form calcium sulfite or sulfate and adhere on the surface of wood. The amount of the product, of course, is very low.

3. The sorption phenomena using wood as sorbent to hold the sulfur dioxide includes both the process „of absorption and adsorption. This 18 because wood has large porous cell cavities and can hold a certain amount of molsture. The term "Absorption" 18 used to define any other condition In which 11quid or gases are engulfed by another substance; solution, chemical reaction, diffusion, or capillaxy action may be involved. The term "Adsorption" Is used to define the condition in which the gases, liquids or dissolved substances are condensed on the surfaces of solids through intermolecular attraction.

4. All woods can be considered as porous in the broad sense. That 18, they possess air space. This void air space Imposes limits on the amount of water it can absorb and is therefore the determining factor in the woodIiquid relationship. Also, the porosity of wood provides.for good characteristics of physical adsorption.

5. Wood is a cellular material and can hold a large amount of molsture In its cell cavities. The amount of molsture that wood can contain in 


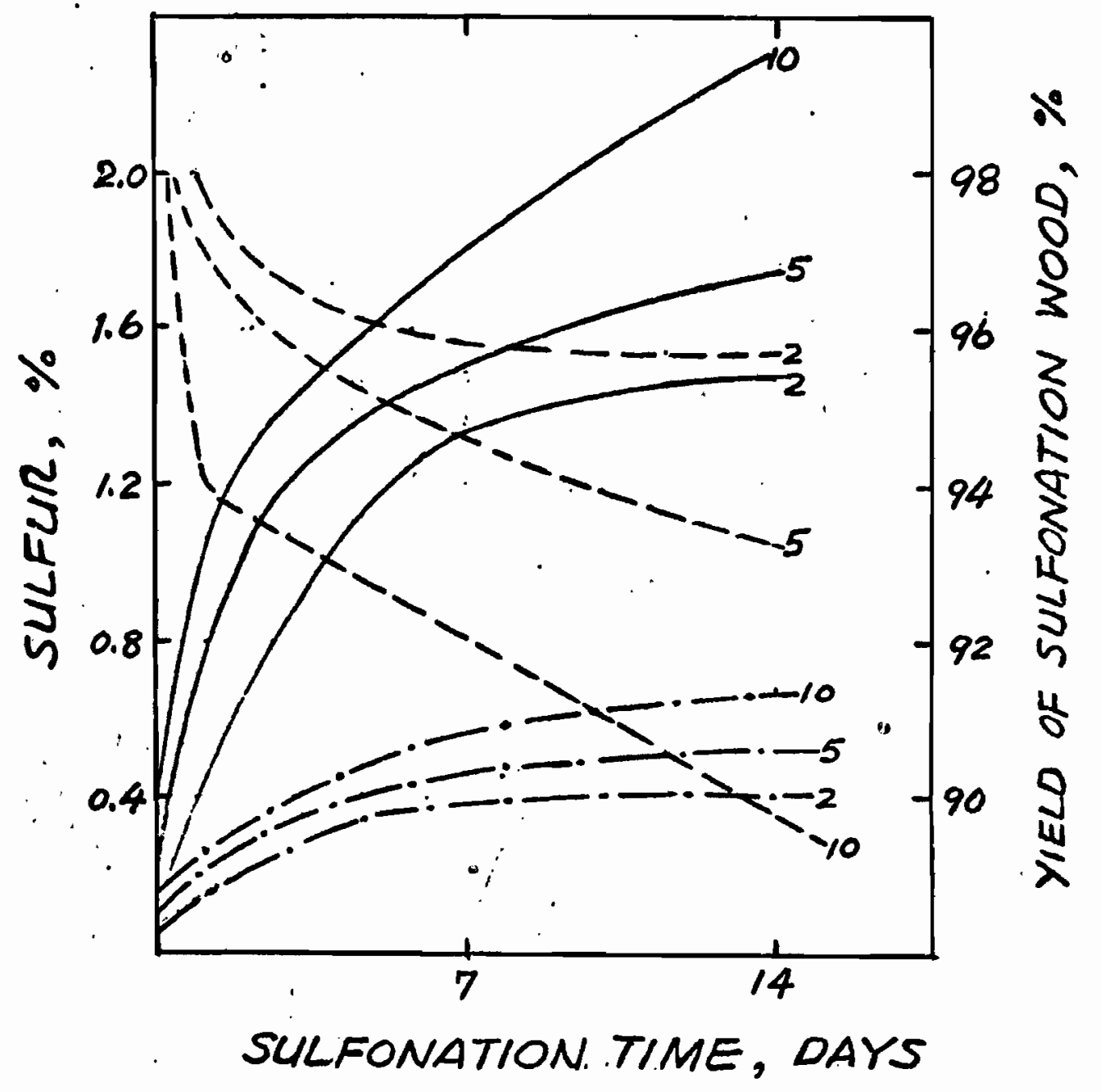

12. 2. Sulfonation of spruce groundwood with 2, 5, and 10\% $\mathrm{SO}_{2}$ solutions: $21 \ldots,(\%)$ sulfur in Iignin;

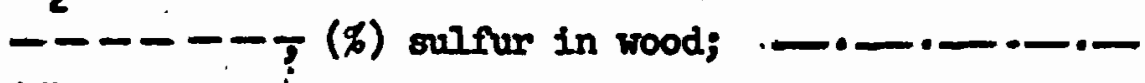
(\$) yield of surfonated rood. 


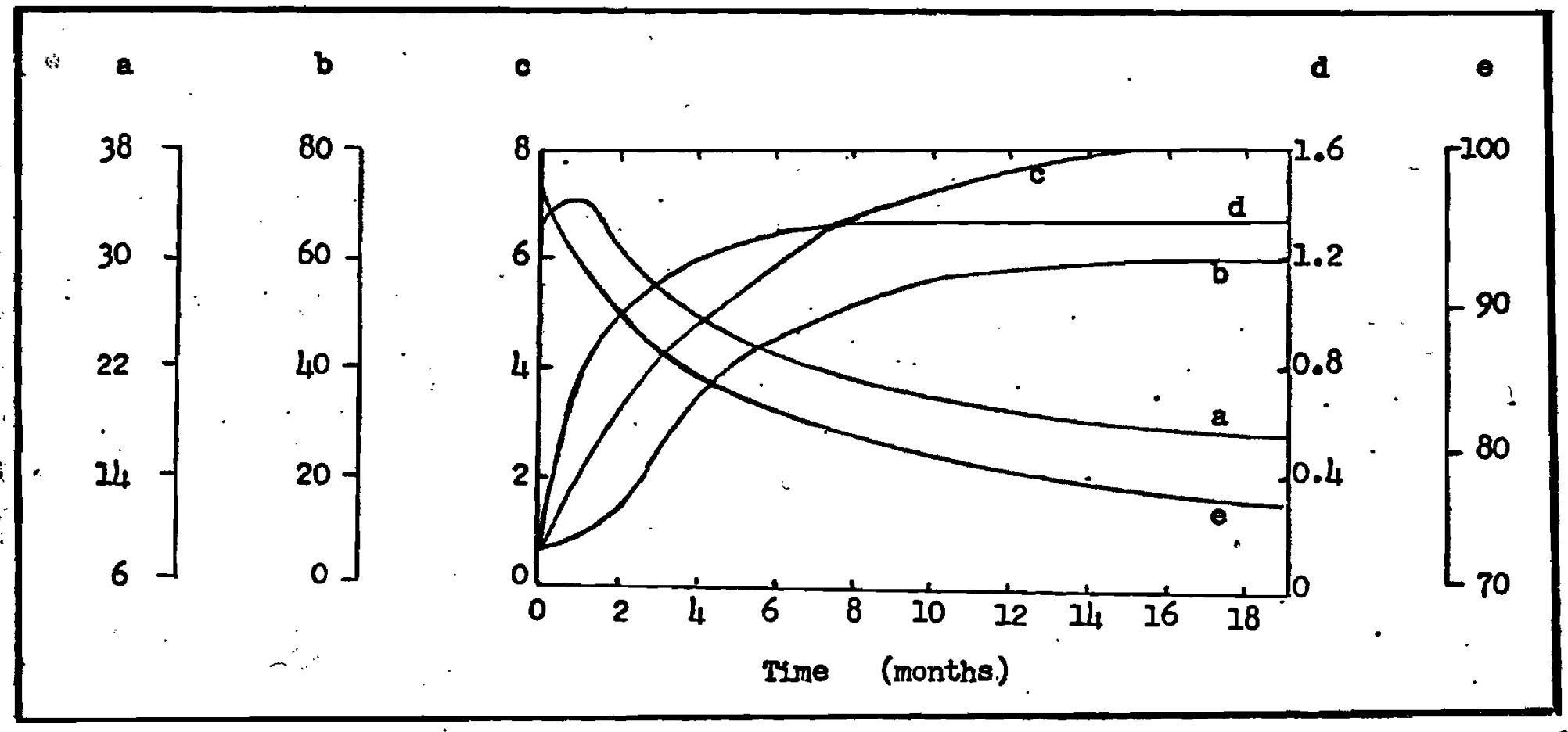

Fig. 3. Sulfonation of hemlock protolignin with $10 \% \mathrm{SO}_{2}$ solution at room temperature:

a, IIgnin In wood (q)

c, sulfur in lignin (\%) b, lignin dissolved (\%)

d, sulfur in wood (f)

e, gield of sulfonated wood (\%) 
this waterlogged condition varies according to the kind and to the piece, ranging from 40 percent of the ovendry weight for the heaviest kinds of wood to nearly 2,000 percent for the lightest. (4)

6. Sulfur dioxide is quite soluble in water and its solubility has been reported by Sherwood (29) in 1925 (see Appendix I). We can, therefore, Imagine that oulfux dioxide will be retained in the wood cell walls by dissolving it into water.

a

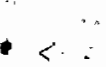


CHAPTER III

THE PROCESS OF SORPTION

1. The Absorption process

Absorption $(11,32)$ is a unit operation in which a soluble component of gas mixture is dissolved in a liquid. This is one of the techniques for transferring materlal from one homogeneous phase to another and is based mostly on the equilibria between two phases. The apparatus used for contacting a liquid and a gas stream continuously may be constructed in several different ways: 1) a tower filled with an irregular solid packing material, 2) an empty tower into which the liquid is sprayed, or 3) a tower containing a. number of bubble-cap or sieve plates. Ordinarily, the gas and liquid stream flow countercurrently through the equipment in order to obtain the greatest rate of absorption. Occasionally, gas absorption operations are carried out in spray columns, wet-wall columns, stirred vessels, or mechanically alded devices.

2. The adsorption process $(8,24)$

Intermolecular attraction between the solid and gaseous or liquid solutes may cause such solute molecules to be selectively retained in the pores or cavities, resulting in their being separated from the carrier gases. As Indicated by Nonet (9) almost all sorbents can be considered to contain a Bignificant fraction of micropores, ranging from 5 to 60 percent by volume. The adsorption processes can be classified in two waye: 1) chemisorption and . 2) physisorption. 
2.1 Chemisorption: At higher temperatures, adsorption may occur through a true reaction or chemical bonding. This is termed chemisorption. Chemisorption is the'result of much stronger binding forces, comparable with those leading to' the formation of chemtcal compounds. This adsorption may be regarded as the formation of a sort of surface compound and 18 seldom reversible. Fig. 4 is a typlcal chemisorption case, oxygen on charcoal at $100^{\circ} \mathrm{C}$.

2.2 Physisorption: Physical adsorption 1s due to the operation of forces between the solid surface and the adsorbate molecules that are similar to the van der Waals forces between molecules. In contrast to chemfsorption, physisorption generally is quite readily reversible, 1.e., when the pressure is decreased, the adsorbed gas is desorbed along the same 1sotherm curve. The case of nitrogen on silica gel at $-196^{\circ} \mathrm{C}$, Fig. 4, is an example of physisorption. A comparison between chemlsorption and physisorption is given In Table III.

Adsorption is usually analogous to a condensation of gas molecules. Its selective action 18 most, pronounced in a monomolecular layer next to the solid surface, but at times selectivity may persist to a helght of three or four molecules. Adsorption capacity of a solid for a solute tends to. Increase with the fluid-phase concentration of the solute. The effective rate of adsorption 18 determined by one more of several diffusional steps. Individual steps in the transport mechan 1sm, any one of which may restrict the overall performance in a certain region of operating condition, are: (1) Diffusion in the solid phase (or, for an adsorbent, diffusion in the adsorbed surface layer).

(2) Reaction at the phase boundartes.

(3) Pore diffusion in the fluid phase within the particles. 


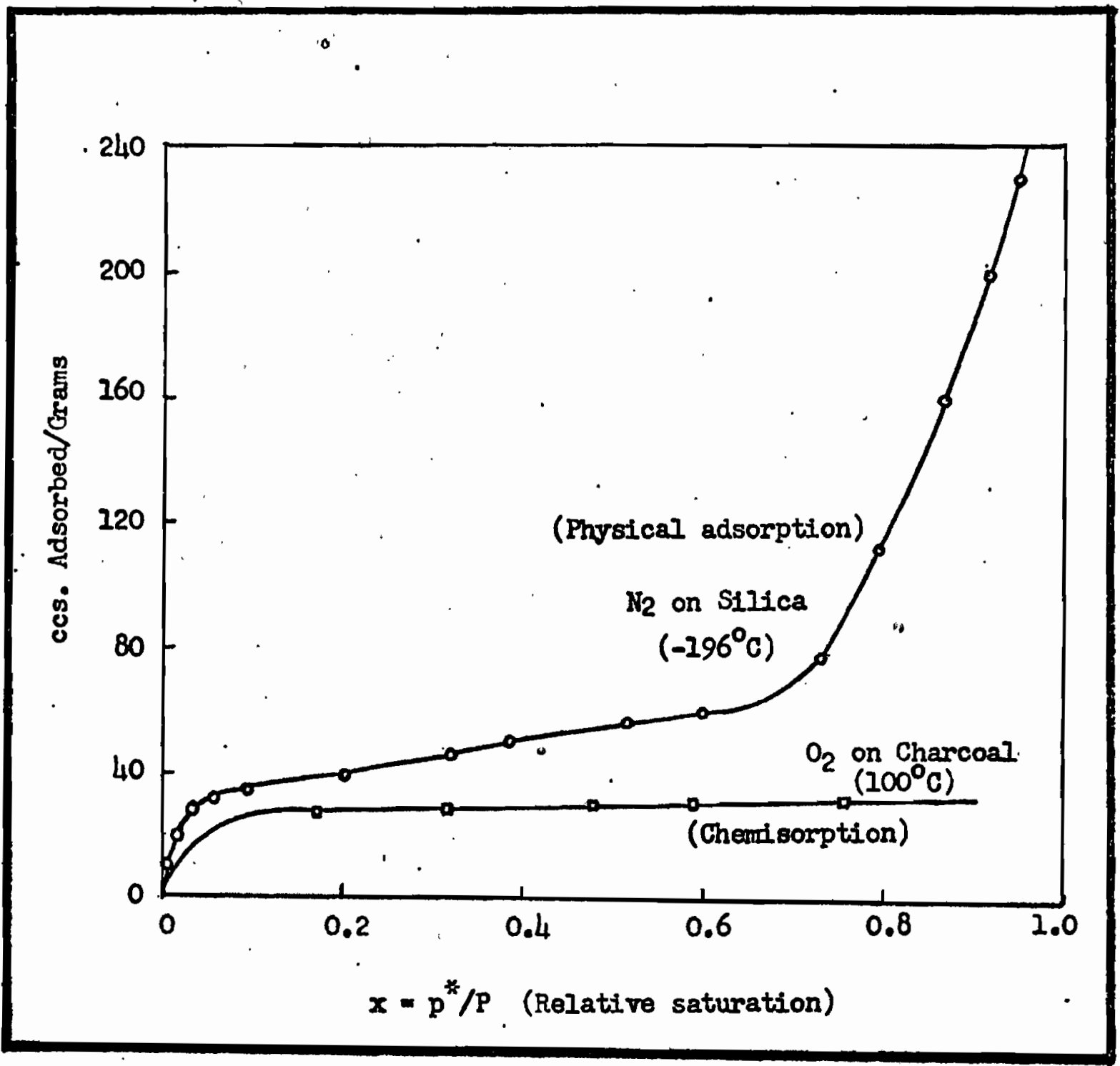

Fig. 4. Two typiosl examples of adsorption isotherms 
COMPARISON OF PHYSICAL ADSORPTION AND CHEMISORPTION

- Physical Adsorption Chemisorption

Heat of adsorption

Rate of adsorption

Specific1ty

Surface coverage

Adsorption above critIcal temperature

Adsorption at low partlal pressure

Adsorption at high partial pressure.

Activation energy

Quant1ties adsorbed per unit mass
Small, same order as normal liquefication

Controlled by resistance to mass transfer

Rapid rate at low temperatures

Low, entire surface avallable for physical adsorption

Complete and extendable to - mult1layer 8

None

Smal1

Large, may extend to infinite amount

Low, nearly negligible

H1gh
Large

Large, many times greater than the heat of normal liquefication

Controlled by resistance to surface reaction Negligible rate at low temperatures High, Chemisorption inited to active sites on the surface

Incomplete and 11mited to unimolecular layer

No restriction

Slight Increase

H1gh, corresponding to a chemical reaction

Low 
(4) Mass transfer from the flowing phase to the external sufraces of the sorbent particles.

(5) Mixing between different parts of the contacting equipment.

3. Adsorption equilibria and isotherm

The amount of gas adsorbed by a solid under equilibrium conditions any be expressed either as percentage by weight or else as the mass or volume of gas (reduced to standard condition), both on the basis of unit mass of gas-free adsorbent. In general, adsorption isotherms, in which the volume of gas adsorbed is plotted against partial pressure at various parameters of constant temperature, are commonly used. The plot of adsorption isotherms can be simpliffied by plotting the volume or mass of gas adsorbed against the relative saturation of the gas instead of against partial pressure. This is shown in $\mathrm{Fig}$. 5, where the relative saturation 1 s defined by the following ratio:

$$
x=p^{*} / \mathbf{p}
$$

where

$$
\begin{aligned}
& p^{*} \text { - equilibriun partial pressure of vapor } \\
& p \text { - saturation vapor pressure }
\end{aligned}
$$

There are five general types of isotherms of adsorption (6) as shown In Fig. 5. In type I the adsorption isotherm is hyperbolic, approaching a constant asymptotic value at a relative saturation of unity. The explanation of this performance 1s that adsorption is restricted to a surface layer one molecule thick. In type II the adsorption curve is S-shape and increases to infinity as the relative saturation approaches unity. The explanation of this behavior is the formation of a multimolecular layer of indefinite thickness. In type III the curvature of the adsorption isotherm is convex toward the side of abscissas. The second derivative of the curve is thus always positive. The amount of gas adsorbed increases without 11mit as its 


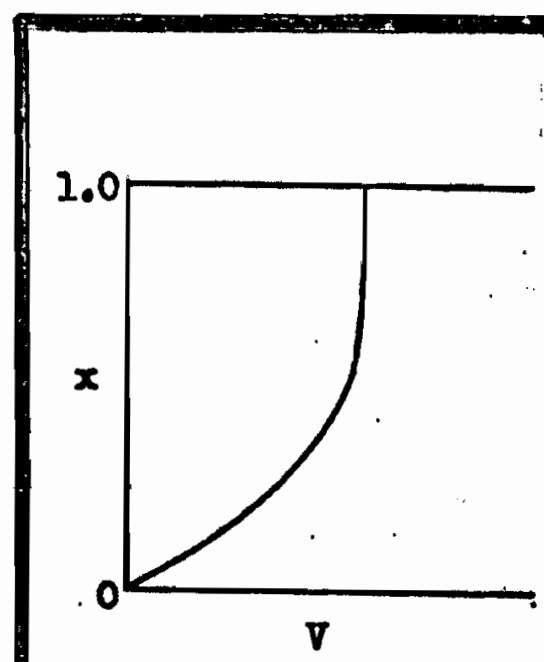

Type I

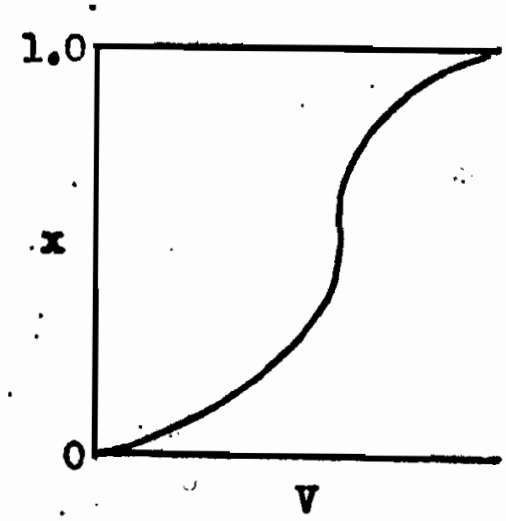

Type II

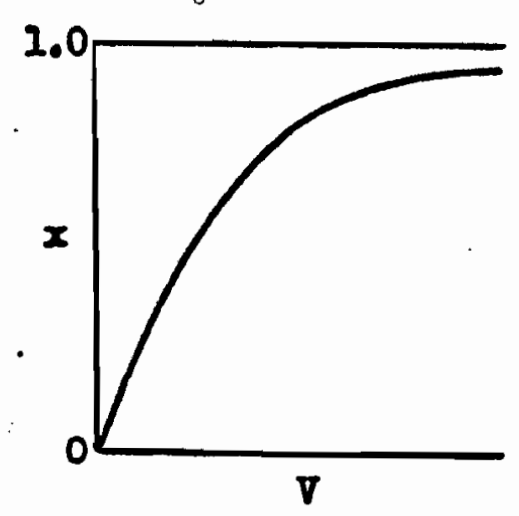

Typo III

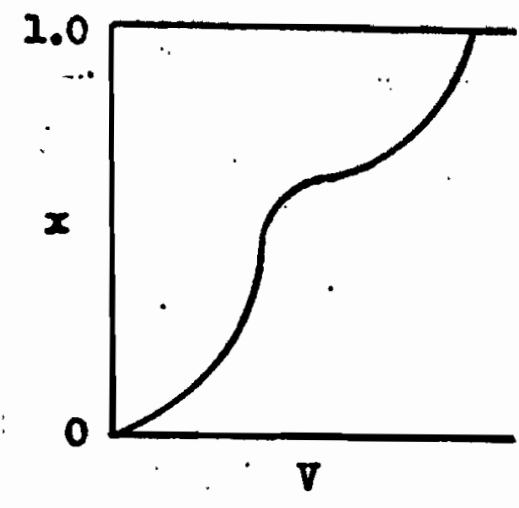

Type IV

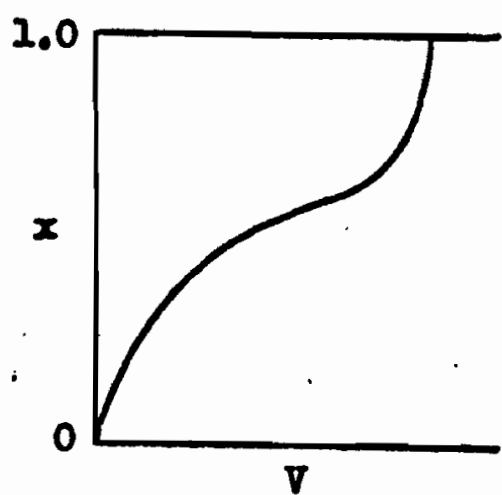

Type V

where $\quad \nabla=$ concentration of adsorbate on the adsorbent, gm. adsorbed m. soild.

- $x$ - Relative saturation $\left(p^{*} / P\right)=$ Equilibrifum partial pressure of vapor/Saturated rapor pressure.

\section{FYg. 5. : Types of adsorption isotherms}


relative saturation approaches unfty. In this case as in type II an infinfte molecular layer is possible. Type IV is similar to type II in the low and Intermediate ranges of relative saturation, but the values of $V$ (the concentration of adsorbate on the adsorbent) approach a maximum finite value at a relative saturation of unity. The high values of $V$ are accounted for by capillary condensation, the maximum value corresponding to complete filling of the capillarles. Type V 18 simflar to type III at low and intermediate ranges of relative saturation but approaches a maximum finite value for $V$ at relative saturation of unfty. This behavior is accounted for by capillary condensation and the buflding up of a layer of finfte thickness at saturation. The Initial convex curvature can be accounted for by the heat of adsorption of the first layer becoming less than the heat of normal condensation due to Interaction.

There is no general equation sultable for all types of adsorption 1sotherms which has been developed from theoretical consideration. On a theoretical basis, Langmulr (20) developed an equation for type I, the aimplest type of adsorption 1sotherm which is restricted to single molecular layer, assuming: 1) at any pressure less than saturation the amount of gas adsorbed is proportional to the partial pressure of the gas and to the fraction of the ourface. left uncovered, 2) the adsorbed gas has not dissoclated nor Interacted. On this basis, he developed the following equation:

$$
v=\frac{v_{m}^{b p}}{1+b p}
$$

where $V=$ volume of gas $\left(0^{\circ} \mathrm{C}, 760 \mathrm{~mm} \mathrm{Hg}\right)$ adsorbed per untt mass of adsorbent. $\nabla_{m}=$ volume of $8 a s\left(0^{\circ} \mathrm{C}, 760 \mathrm{~mm} \mathrm{Hg}\right)$ adsorbed per un1t mass of adsorbeṇt to cover surface with a layer ope molecule thick.

b - empiricel constant, in reciprocal pressure units. 
Bienstock et. al. (2) had developed a satisfactory method in the application of exponential equations for adsorption of atmospheric sulfur dioxide. In this method the Freundlich equation was applied to express the adsorption of the gas by a varfety of solid materials and has the following general form:

$$
\mathrm{M}_{\mathrm{g}} / \mathrm{M}_{\mathbf{8}}=\mathrm{KC}^{\mathrm{n}}
$$

where $\quad M_{g}=$ the mass of gas retained by the adsorbent, $\mu g$.

- $M_{8}=$ the mass of adsorbent in bed, 8 .

$\mathrm{R}, \mathrm{n}$ - proportionality constant

$C$ - concentration of adsorbate gas in the effluent from the adsorbent, $\mu \mathrm{g} \cdot / 11$ ter

4. Calculation for the process of adsorption

4.1 Calculation of gas adsorbed on the solid material $(25,36)$. The amount of gas adsorbed by the adsorbent bed in time dt can be expressed as follows:

$$
\begin{aligned}
d M_{g} & =\left(c_{b}-c_{a}\right) \nabla \cdot d t \\
M_{g} & =v \int_{0}^{t}\left(c_{b}-c_{a}\right) d t
\end{aligned}
$$

where $M_{8}=$ the mass of gas adsorbed

$c_{b}=$ the adsorbate concentration in the influent gas

$C_{a}=$ the adsorbate concentration in the effluent gas

$V$ - gas flow rate

and the change of capacity of adsorbent, $d G$, within the time dt is

$$
d G=d M_{g} / M_{s}
$$

Combining Eq. [4] and [5], we have

$$
\frac{d G}{G_{b}-C_{a}}=\frac{V}{M_{8}} d t
$$


Put into boundary conditions, $t=0$, and $G=0$, then we have

$$
\int_{0}^{G} \cdot \frac{d G}{G_{b}-C_{a}}=\frac{V \cdot t}{M_{8}}
$$

or

$$
t=\frac{M_{g}}{V} \int_{0}^{G} \frac{d G}{G_{b}-C_{a}}=\frac{M_{s} G_{c}}{V\left(G_{b}-C_{a}\right)}
$$

where $M_{8}=$ the mass of adsorbent in bed

$G_{C}=$ cumulative amount of adsorbate on the adsorbent

Integrating Eq. [6] and solving. It in explicit form for $C_{a}$, we obtain

$$
C_{a}=C_{b}\left(1-\exp \left(-k V t / M_{s}\right)\right)
$$

\subsection{Estimation of adsorber. \\ There are several criterla proposed as guidelines for adsorber design:}

4.2.1 The pseudo gas velocity should be as high as the adsorber height restrictions and pressure drop limitations will permit in order to achieve efficlent mass transfer possibly on the order of 45 feet per minute. 4.2.2 Adsorbent mesh size should be as small as the pressure drop limitations, granule strength and screen size will permit.

4.2.3 The adsorbent bed should be at least as long as the transfer zone length for the key component in the recovered product. 4.2.4 The length-diameter ratio $(L / D)$ of the adsorbent bed should be as large as the height restrictions, pressure drop and fabrication economics will permit.

4.2.5 The saturation time interval must be at least as long as the minimum time required to regenerate and cool the alternate adsorber. 4.2.6 Optimum controi of adsorber switching time must be based on continuous 
monitoring of the key component concentration in the effluent gas.

In the 11ght of above-mentioned criterla of adsorption design, Campbell, et. al (7) have developed an equation for the dlameter of required adsorbent bed :

$$
D=\left[25\left(H_{g}\right)\left(T_{f}\right) /\left(P_{f}\right)\left(V_{g}\right)\right]^{1 / 2}
$$

where $D=$ required adsorbend bed dlameter, ft.

$$
W_{8}=\text { gas flow rate, million cu. } f t \text {. per day }
$$$$
\mathbf{T}_{\mathbf{f}}=\text { Temperature in adsorber, }{ }^{\circ} \mathbf{R}
$$$$
P_{f}=\text { Pressure in adsorber, psia }
$$$$
V_{8}=1 \text { inear gas velocity, ft./min. }
$$

The diameter of the adsorber used in the experiments has been checked, according to equation [9] In Appendix II. 


\section{CHAPTER IV}

EXPERIMENTAL PROCEDURES

Th1s experiment used woodchips as an adsorbent to remove sulfur dioxide from a gas stream by an adsorption process. The overall experimental process was carrled out in the Atr Pollution Laboratory of Portland State University and was initlated in the following ways:

1. A process flow diagram for the experiment was set up.

2. The required equipments were collected and the experimental train was assembled:

3. The kind of wood to be used as the adsorbent was determined, and an adequate slze of woodchips, was selected, dried and stored.

4. A calibration curve was prepared and an $\mathrm{SO}_{2}$ monitor was calibrated.

The procedures for this experiment are stated in detall as follows:

1. For the flow dlagram of the adsorption of sulfur dioxide on Douglas fir woodchips, see $\mathrm{FIg} .6$.

2. The following equipment was used in this experiment:

2.1 Flowmeter: Predictable flowmeters manufactured by Manostat Corp., New York, Cat. No. 36-541-14, were used for measurement of gas flow ranging from 7.5 to $2,120 \mathrm{ml} . / \mathrm{minute}$.

2.2. Thermometer: Ordinary thermometers were used in the range of $-10^{\circ} \mathrm{C}$ to $100^{\circ} \mathrm{C}$.

$2.3^{-} \mathrm{SO}_{2}$ distribution apparatus:

As shown in $\mathrm{FIg}$. 7, the $\mathrm{SO}_{2}$ apparatus 18 a side-connected U-tube with one side filled with glass beads and the other side with one or more $\mathrm{SO}_{2}$ 


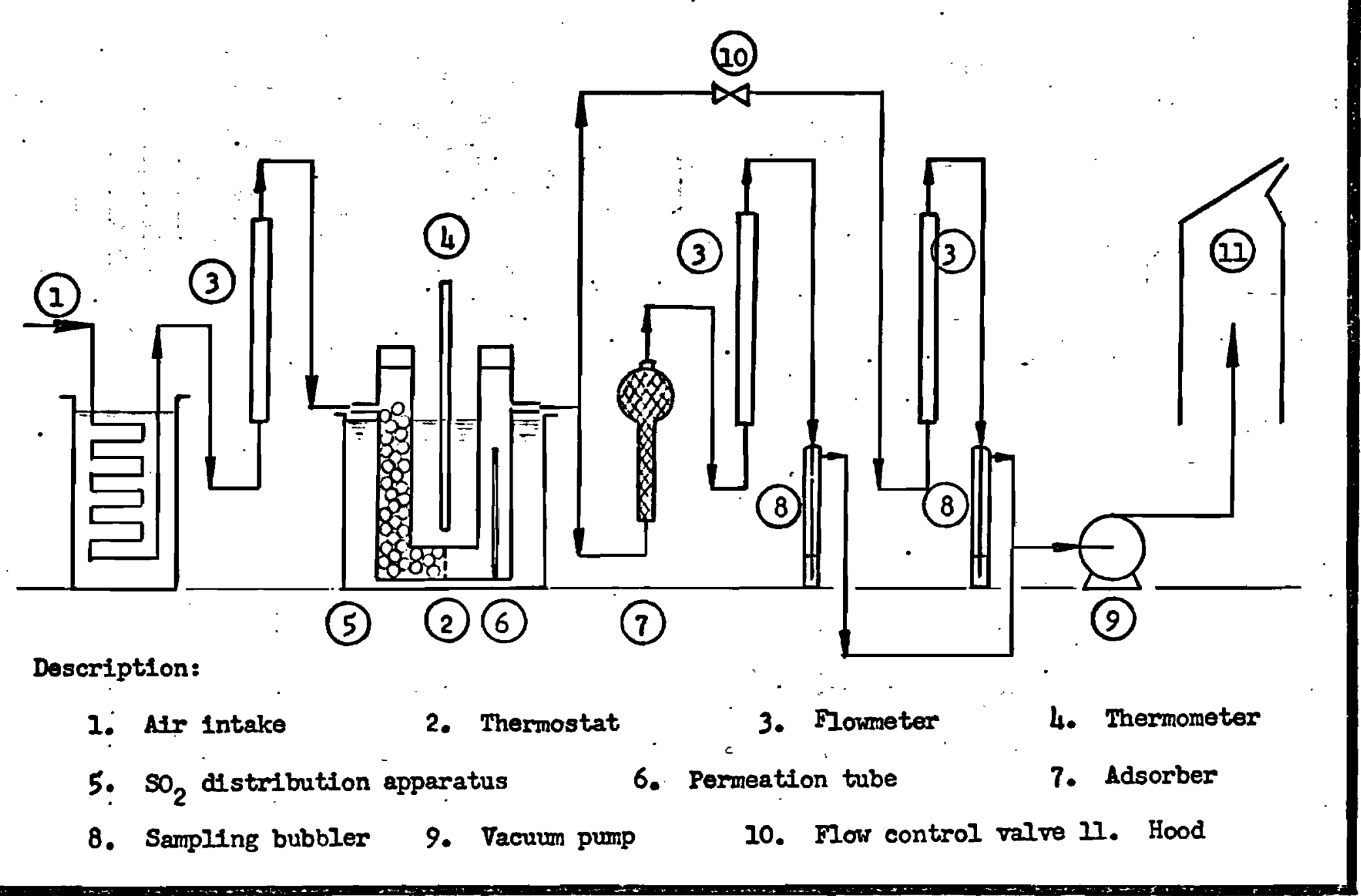

Fig. 6. Flow diagram for the adsorption of sulfur dioxide on Douglas fir woodchips 
Removable, Inert-lined caps

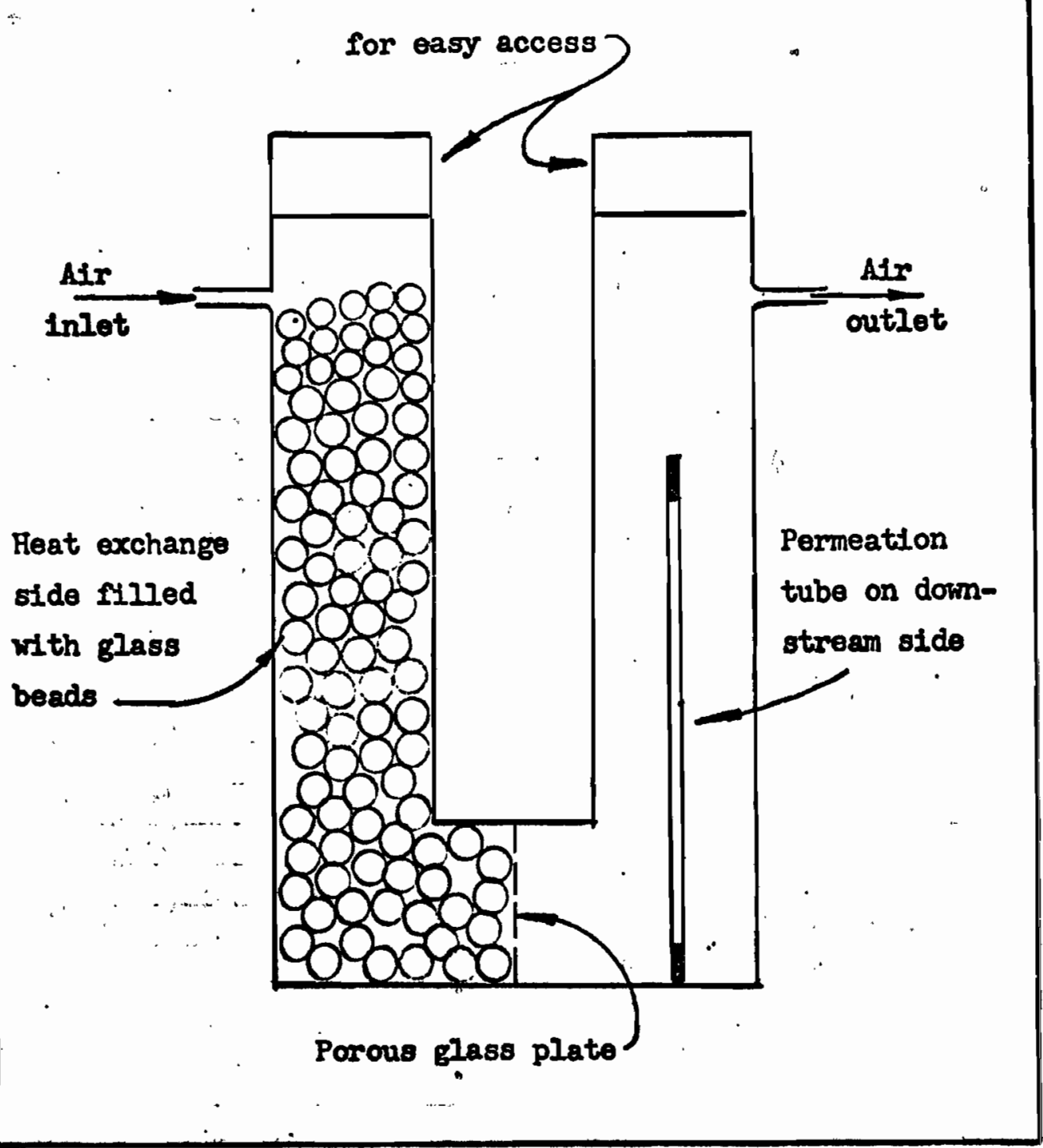

Fig. 1. $\mathrm{SO}_{2}$ divtribution apparatus 
permeation tubes.

$2.4 \mathrm{SO}_{2}$ permeation tube: These tubes are made with plastic and filled with liquid $\mathrm{SO}_{2}$ and both ends of the tube sealed. After Initial conditioning, the permeation rate of $\mathrm{SO}_{2}$ in a section of plastic tubing proceeds at a constant rate which depends on the temperature. The length of tube needed to produce the desired gas concentration can be estimated (22) by the following equations:

and $\quad L=(C \times F) /\left(K \times P_{t}\right)$

$$
C=\left(K \times P_{t} \times L\right) / F
$$

where $\mathrm{C}=\mathrm{SO}_{2}$ concentration in gas stream, $\mathrm{ppm}$ by volume ,

$$
\begin{aligned}
R= & \text { variable conversion factor depending on gases used, } \\
& \text { for } \mathrm{SO}_{2}, \mathrm{~K}-0.382 \text { e } 1 \text { atm. and } 25^{\circ} \mathrm{C} \text {. } \\
P_{t}= & \text { permeation rate for stated operation temperature, } t \\
& (\text { see } \mathrm{F} 1 \mathrm{~g} \cdot 8 \text { ). } \\
\mathrm{L}= & \text { active permeation tube length, } \mathrm{cm} . \\
F= & \text { Flowrate of carrier gas past the tube, } \mathrm{cm}^{3} / \mathrm{min} .
\end{aligned}
$$

\subsection{Adsorber:}

An ordinary plastic or glass gas dryer was used as the adsorber. The size of the adsorber, used was $1.7 \mathrm{~cm}$. diameter X $15 \mathrm{~cm}$. length with a 3.1 cm. diameter bulge. The volume estimated is about $41^{4} .6 \mathrm{cu}$. cm. Calculations of the required dlameter of the adsorber, according to Campbell, et. al, are presented in Append1x II.

\subsection{Sampling bubbler:}

A series of all-glass midget impingers, which can be supplied by Ace Glass Company or Gelman Instrument Company, was used for sampling of $\mathrm{SO}_{2}$ in the carrler gas before and after the adsorber. . 


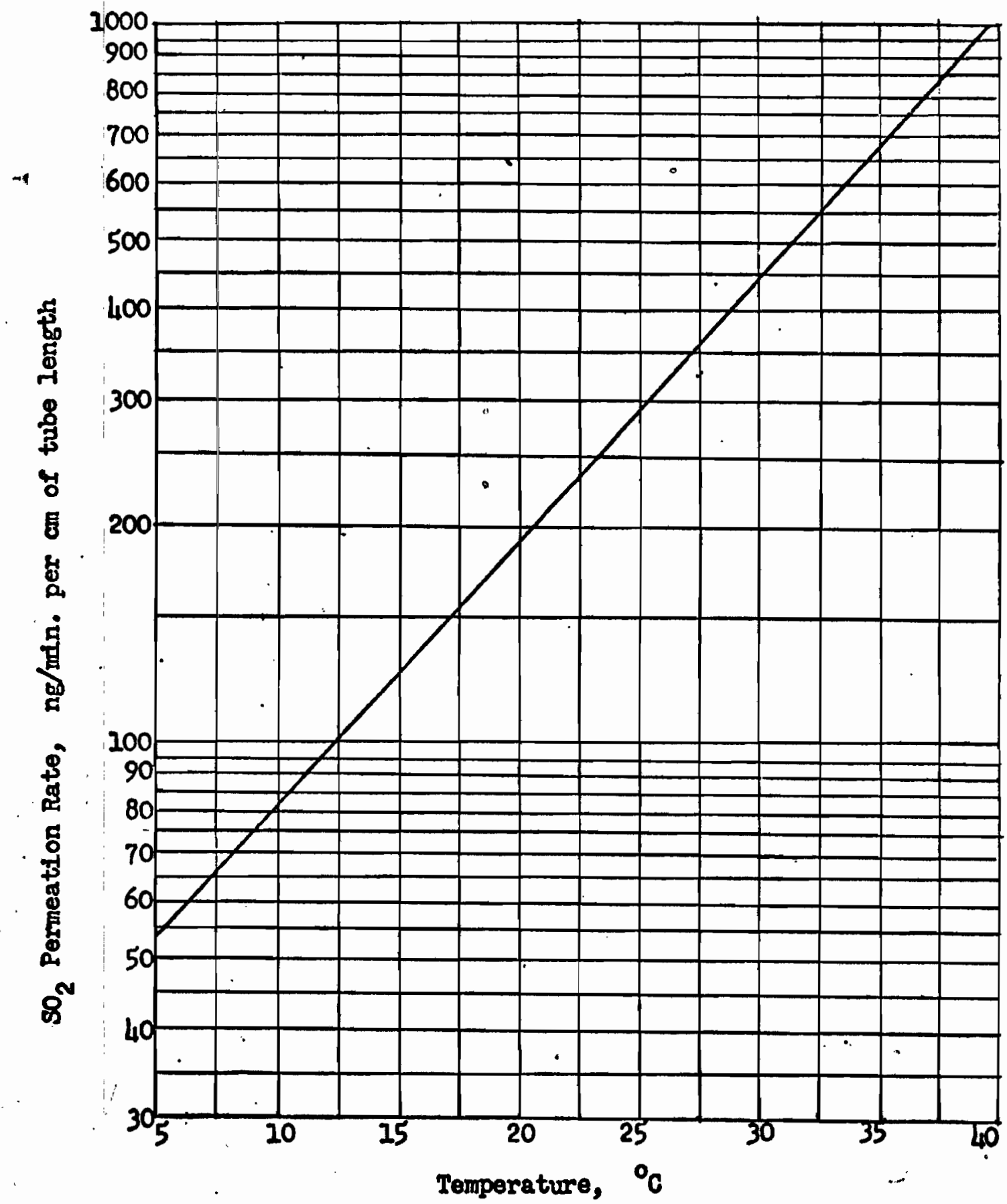

Fls. 8. $\mathrm{SO}_{2}$ nominalo permeation rates for "Dynacal" tubes 


\subsection{Vacuum pump:}

An ollless air compressor with $1 / 12$ h.p., 1,725 rpm, Model No. LG, Identification No. GH, was used to draw the gas through the system. This pump is manufactured by Bell Gossett Co., Morton Grove, I11.

\subsection{Spectrophotometer :}

This experiment used a method of colorimetric analysis (West and Gaeke Method) to detect the trace amount of $\mathrm{SO}_{2}$ that existed in a solution. A type of spectrophotometer, made by B L Company was employed.

$2.9 \mathrm{SO}_{2}$ monitor:

A Davis $\mathrm{SO}_{2}$ Monitor, Model 70Al, was used to obtain continuous readings. This $\mathrm{SO}_{2}$ monitor operates on the principle of electrical conductance.caused by Ionization of dissolved material.

: 3. Procedure for obtaining of results:

Data were obtained both by wet analysis and $\mathrm{SO}_{2}$ monitor readings. $\rightarrow$ The readings of the $\mathrm{SO}_{2}$ monitor were occasionally checked by the West and Gaeke Method $\left(16,17,34\right.$ ) (see Appendix III), in which $\mathrm{SO}_{2}$ reacts with sodium tetrachloromercurate to form the dichlorosulfitomercurate ions, then reacts with acid-bleached para-rosaniline and formaldehyde to produce a red pubple color. A spectrophotometer set at a wavalength of $560 \mathrm{m \mu}$ is then used to detect the different concentrations of $\mathrm{SO}_{2}$ in the samples. In the overall study, about two-thirds of the results were obtained directly by the West Gaeke method because of its great accuracy.

4. Adsorbent used: Douglas fir

4.1 The adsorbent used in this experiment was Douglas fir. Douglas fir (Pseudotsuga taxifolla) was named after the Scottish botanist, David Douglas. It is not a true fir, but belongs, botanically, to a separate species. The Douglas fir is regarded as the principal timber tree in the Northwest, 
and comprises over $70 \%$ of the lumber produced in that area. The Douglas fir of the coast region 18 more widely used than any other American softwood. Due to contemporary framing and structural techniques, Douglas fir has become Increasingly important as a bullding materlal for engineering structures. Its constituents make this species Ideal for such usages as light framing -for residential construction, and heavy framing for durable rallway and highway bridges, and also for marine structures. Other uses for this wood Include: rallway ties, mine timbers, boxes, crates, silos, pulp, cooperage, car construction, furniture, containers for corrosive chemicals, and general mill-work.

4.2 There is a great amount of sawdust or woodchips produced in the processing of forest products. Most of these woodchips are considered to be waste materlal, and are, used as land-fills. Some, of course, are utilized by pulpmills, or exported to other countries. However, the quantity is limited. According to Brown (4) and a U.S. Department of Agriculture report (33), 6,828 million cu. $f t$. of sawdust were produced in 1952. Since Douglas fir Is a main timber cut in the U.S., selection of Douglas fir as an experimental adsorbent approaches both problems of afr pollution and solid waste disposal. 4.3 Selection of adsorbent size:

Douglas fir was screened to separate an adequate and homogeneous materials for the experiment. Some physical and chemical properties of Douglas fir are given in tables IV and V. U.S. Standard sleves (ASTM E-11) No. 4 (Opening: $0.187 \mathrm{in}$. or $4.76 \mathrm{~mm}$ ) and No. 8 (Opening: $0.0937 \mathrm{in}$. or $2.38 \mathrm{~mm}$ ) were used for selection of sawdust sizes. Reasons for selection of uniform size are: i) Larger sodids do not give enough contacting surfaces between - carrier as and adsorbent. 2) Fine sawdust packed in the adsorber would produce' a greater drop in pressure and could, therefore, be blown out through 
TABLE IV

SOME PHYSICAL PROPERTIES OF DOUGLAS FIR

$\cdot$

1. Color :

Heartwood: Orange red to red, sometimes yellow

Sapwood: White to pale yellow

2. Weathering: Weathers to dark gray color with 11ttle or no sheen.

3. Growth: Growth rings delineated by pronounced bank of dark summerwood.

4. Decay resistance: Heartwood is moderately durable, sapwood of species 18 non-durable.

5. Weight (Average):

$\therefore$ Volsture content

8
16
20
24

6. Shrinkage and owelling:

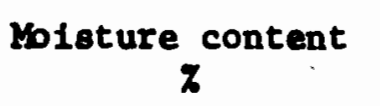

8
16
20

'
8 16
$1 \mathrm{~b} . / \mathrm{ft}^{3} \quad \mathrm{~g} \cdot / \mathrm{cm}^{3}$

33.1

34.3

35.1

35.8

0.53
0.55
0.561
0.572
Linear wt. 1b./1,000 board ft.
2,760

2,860

2,920

2,980

7. W1sture equilibrium:

Soleture content

$$
7
$$

8

10

12

16

20

24
Relative humidity at

$30^{\circ} \mathrm{C} \quad 100^{\circ} \mathrm{C}$

$40 \%$

527

$63 \%$

78.7

$87 \%$

937
467

$59 \%$

697

$85 \%$

90.57

$95.5 \%$ 


\section{SOMR PHYSICAL PROPERTIES OF DOUGLAS FIR}

(CONT INUED)

8. Wo1sture content in hẹartwood, sapwood and chips

$$
\text { Wolsture content (Average for }
$$

Hear twodd

Sapwood

Chips fresh sawn lumber)

$37 \%$

$115 \%$

$56.4 \%$

9. Thermoconductivity: 1 inch of net thickness Average

$$
\begin{aligned}
& K=1.0 \text { at } 15 \% \text { moisture content } \\
& K=0.76 \text { at } 0 \% \text { moisture content }
\end{aligned}
$$

10. Thermal expansion: In unit of length or width for $1^{\circ} F$ of temperature change

$$
\begin{aligned}
& \text { Longitudinal: } 1.7 \times 10^{-6} \text { to } 2.5 \times 10^{-6} \\
& \text { Vertical grain face: } 1.43 \times 10^{-5} \\
& \text { Flat grain face: } 2.07 \times 10^{-5}
\end{aligned}
$$

11. Specific gravity:

$$
\begin{array}{lc} 
& \text { Sp. } 8 r \\
\text { Unseasoned } & 0.45 \\
\text { Atr dry } & 0.48 \\
\text { (12 } 7 \text { molsture content) }
\end{array}
$$

12. Electrical properties:

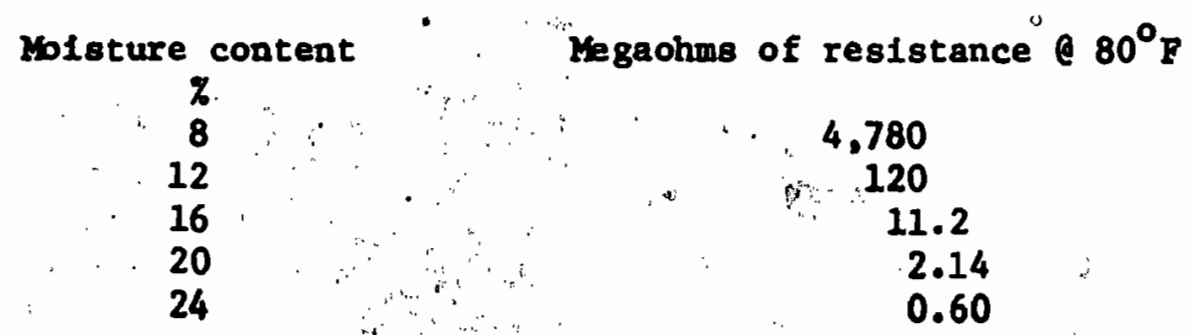




\section{TABLE V}

SOME CHEMICAL PROPERTIES OF DOUGLAS FIR

1. Chemical Compositions:

1.1 Soluble matters:

i.1.1 In alcohol: $4.20 \%$.

1.1.2 In hot water: $3.20 \%$ (Th1s extraction made on residues after alcohol extraction).

1.2 Lignin content: $25.8 \%$

1.3 Holocellulose (Carbohydrate fraction of extractive-free cell wall substance): $65.95 \%$

2. Water effect:

$$
\begin{aligned}
& \text { Residue strength after soaking } \\
& \text { in water } \\
& \text { At room temperature } \\
& \begin{array}{c}
\text { Bolling. } \\
\text { in }
\end{array} \\
& 102 \%
\end{aligned}
$$

\begin{tabular}{|c|c|c|c|c|}
\hline Chemicals & $\begin{array}{l}\text { Room tem } \\
\text { Residue } \\
\text { etrength }\end{array}$ & $\begin{array}{l}\text { erature } \\
\text { Solution }\end{array}$ & $\begin{array}{l}\text { Bolling } \\
\text { Residue } \\
\text { strength }\end{array}$ & Solution \\
\hline HCl acid & $67 \%$. & $5 \%$ & 597. & 17 \\
\hline $\mathrm{H}_{2} \mathrm{SO}_{4}$ acid & $91 \%$ & $20 \%$ & $67 \%$ & 17 \\
\hline $\mathrm{HIO}_{3}$ acid & $65 \%$ & $5 \%$ & 597 & 17 \\
\hline
\end{tabular}

3. Chemical effect: Residue strength after soaking in chemicals compared to water soaking 
the outlet tubing.

4.4 Heasurement of the molsture content in the sawdust:

4.4.1 Separately weigh a contalner before and after f1lling with sawdust. 4.4.2 Place the sawdust In an oven and dry at $100^{\circ} \mathrm{C}$ to constant weight. 4.4.3 The molsture content of the sawdust is calculated in the following equatione:

$$
\begin{aligned}
& W=W_{0}(1-W / 100) \\
& M=100\left(W-W_{0}\right) / W_{0}
\end{aligned}
$$

where $W=$ the weight at initial molsture.

$w_{0}=$ the ovendry weight.

$M$ - the percentage. of molsture in the sample based on ovendry weight.

4.5 Classification and preparation of sawdust molsture content in the experiment :

In order to determine the adsorptivity of sulfur dioxide on woodchips, different molsture contents in sawdust were employed: First, dry sawdust samples were obtained as mentioned previously. Woistened sawdust samples were prepared in the following steps:

4.5.1 An empty dry flask was welghed and the dry sawdust was added. 4.5.2 A volume of distilled water equivalent to the molsture content required to make the required percentage of moisture was added to the dry wood. For instance, exactly $1 \mathrm{ml}$. of distilled water was pipetted Into the flask for 5 grams of dry sawdust to make a $20 \%$ molsture sample assuming that the density of water is equal to 1 .

4.5.3 The flask was stopped and shaken to distribute the water homogeneously: 4 
4.5.4 Immediately after preparing the samples of woodchips, the adsorber was filled and packed. The flask was welghed to determine if any of the sawdust or residue remained in the flask.

4.5.5 Five molsture levels were used:

4.5.5.1 Dry wood (0\% of molsture content).

4.5.5.2 $11 \%$ of motsture centent.

4.5.5.3 $20 \%$ of molsture content.

4.5.5.4 $50 \%$ of molsture content

4.5.5.5 Saturated molsture content.

5. Recording of the experiment:

5.1 The temperature (dry buib and wet bulb temperature), pressure, and the relative humldity of the suppiled alr and the vacuum pressure of the pump were recorded.

5.2 The welght of dry woodchips used for the adsorption, the moisture added, and the residues left in the preparation apparatus were measured before the woodch1ps were packed into the adsorber.

5.3 When samples were taken continuously, the temperature of the water bath (or the thermostat) of the $\mathrm{SO}_{2}$-distributor, total inlet of air flow, the flowrate in each branch, and the sampling time were recorded.

5.4 When the $\mathrm{SO}_{2}$-monitor was used, readings were obtained every half minute. 


\section{CHAPTER V}

\section{EXPERIMENTAL RESULTS}

1. Three atmospheric $\mathrm{SO}_{2}$ concentrations, $1.12 \mathrm{ppm}$., $1.83 \mathrm{ppm}$., and 4.60 ppm., were used. To each of the three concentrations, the selected Douglas fir woodchips were used for the experiments. These woodchips were matched, according to Chapter IV, Section 4.5.5, to five moisture levels. The results of these 15 combinations are presented in Appendix Table 1 to 15 and are shown in figures 9 through 23. The data were plotted in accordance with the calculated results presented in those tables. The experimental time including the preparation of the experiments, ranged from two hours for the shortest experiment to 20 hours for the longest one. For an influent $\mathrm{SO}_{2}$ concentration of 1.12 ppm., $6.25 \mathrm{g.,} 7.00 \mathrm{~g} ., 6.81 \mathrm{g.,} 6.64 \mathrm{g.,}$ and 6.00 8 of woodchips were used. For an influent $\mathrm{SO}_{2}$ concentration of 1.83 ppm., $6.158 \cdot, 6.83 \mathrm{~g} \cdot, 5.85 \mathrm{~g} \cdot, 6.728$ and $7.00 \mathrm{~g}$ of woodchips were used, and for an influent $\mathrm{SO}_{2}$ concentration of $4.60 \mathrm{ppm} ., 6.40 \mathrm{~g} \cdot, 6.71 \mathrm{~g} \cdot, 7.16 \mathrm{~g} \cdot$, $6.93 \mathrm{~g}$. and $6.89 \mathrm{~g}$. of woodchips were used. For the above-mentioned quantities of woodchips, moisture levels of $0 \%, 11 \%, 20 \%, 50 \%$ and saturated were employed.

2. For additional testing of dry wood adsorptivity, concentrations of $\mathrm{SO}_{2}$ of $0.675 \mathrm{ppm}$., $0.775 \mathrm{ppm} ., 0.85 \mathrm{ppm}$. and $3.60 \mathrm{ppm}$. were employed. Comparison of the adsorption of sulfur dioxide on dry wood for all $\mathrm{SO}_{2}$ influent concentrations 18 shown in Fig. 24. It is clear from the experimental results that the dry woodchips do have some features in the adsorption of oulfur dloxide.

3. Comparisons of $\mathrm{SO}_{2}$ saturation rates in the different molsture con- 


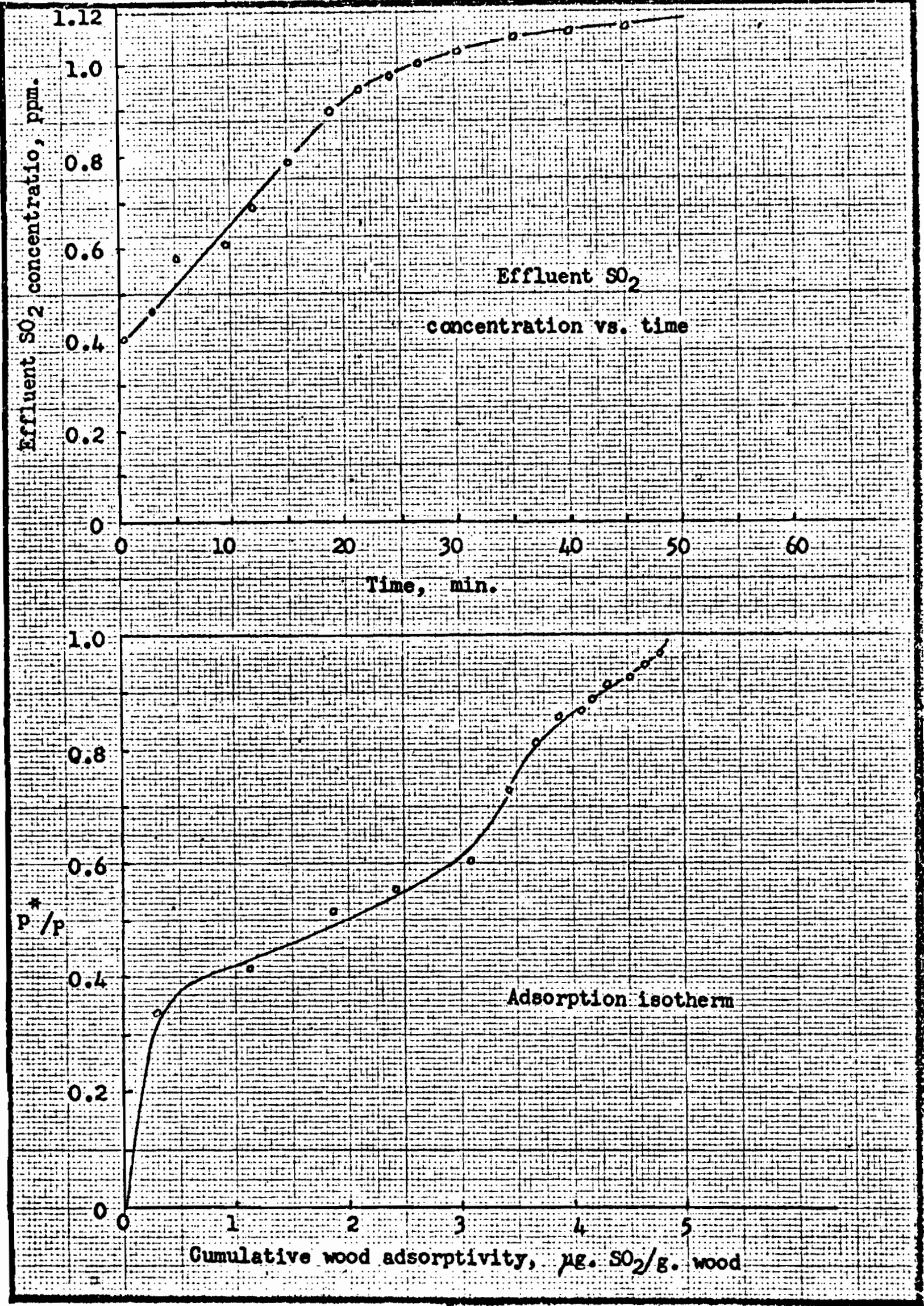

Fle. 9. The adsorption of $\mathrm{SO}_{2}$ on dry wood at an influent $\mathrm{SO}_{2}$ concentration of $1.12 \mathrm{ppm}$. 


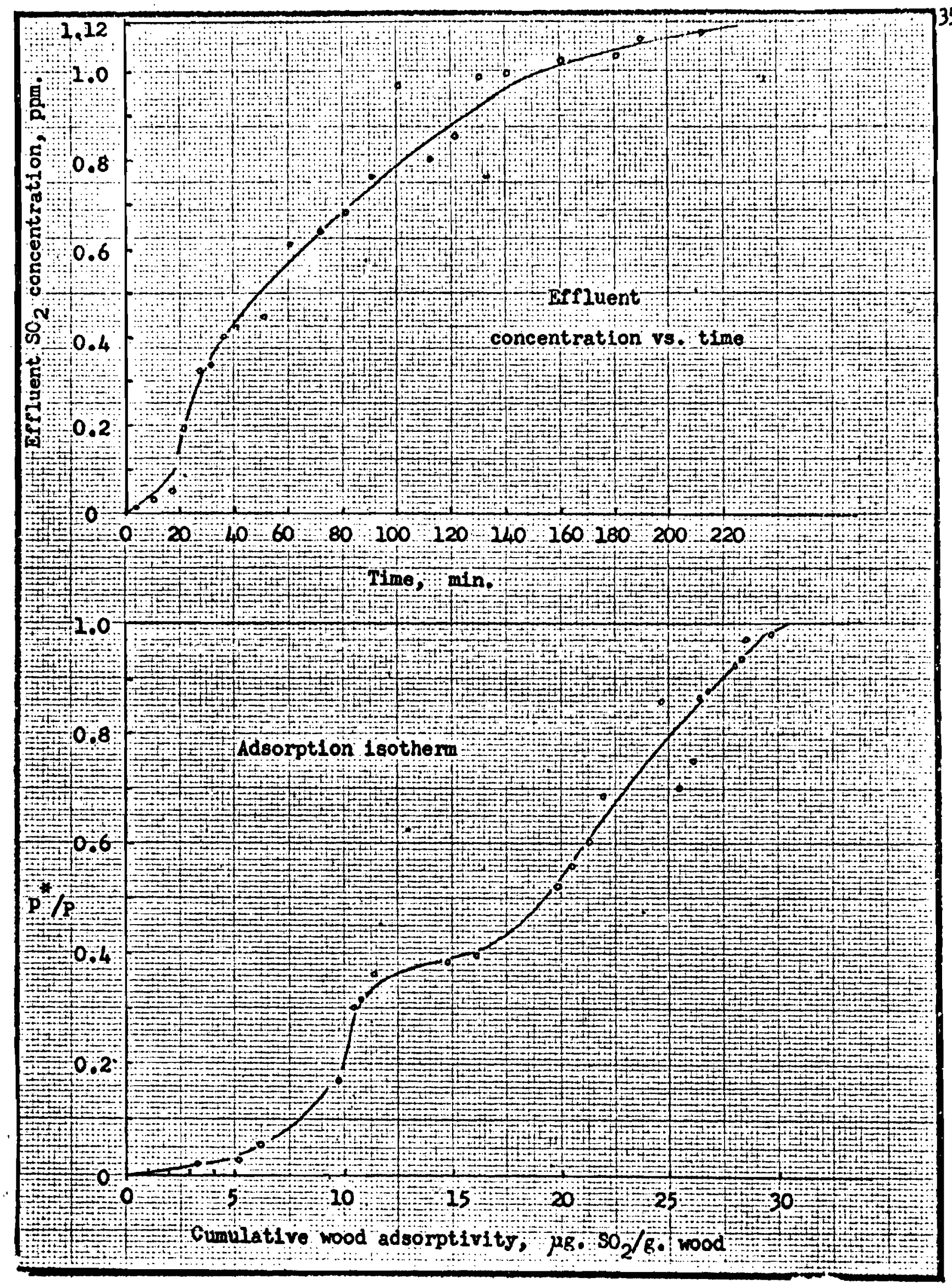

Fig, 10. The Adsorption of $\mathrm{SO}_{2}$ on wood with $17 \% \mathrm{H}_{2} \mathrm{O}$ at an influent $\mathrm{SO}_{2}$ concentration of $1.12 \mathrm{ppm}$. 


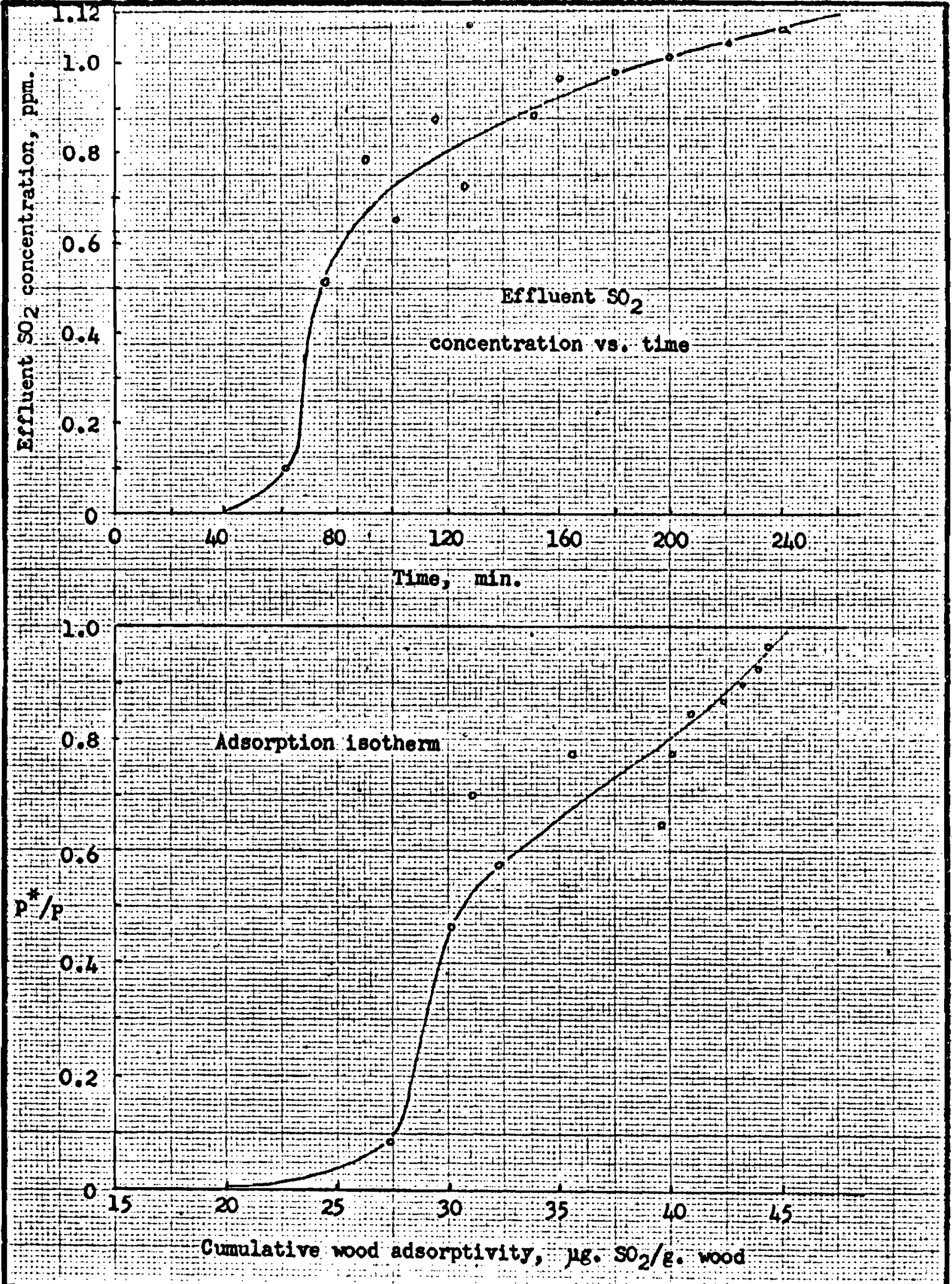

Fig. 21. The adsorption of $\mathrm{SO}_{2}$ on wood with $20 \% \mathrm{H}_{2} \mathrm{O}$ at an influent $\mathrm{SO}_{2}$ concentration of $1.12 \mathrm{ppm}$. 


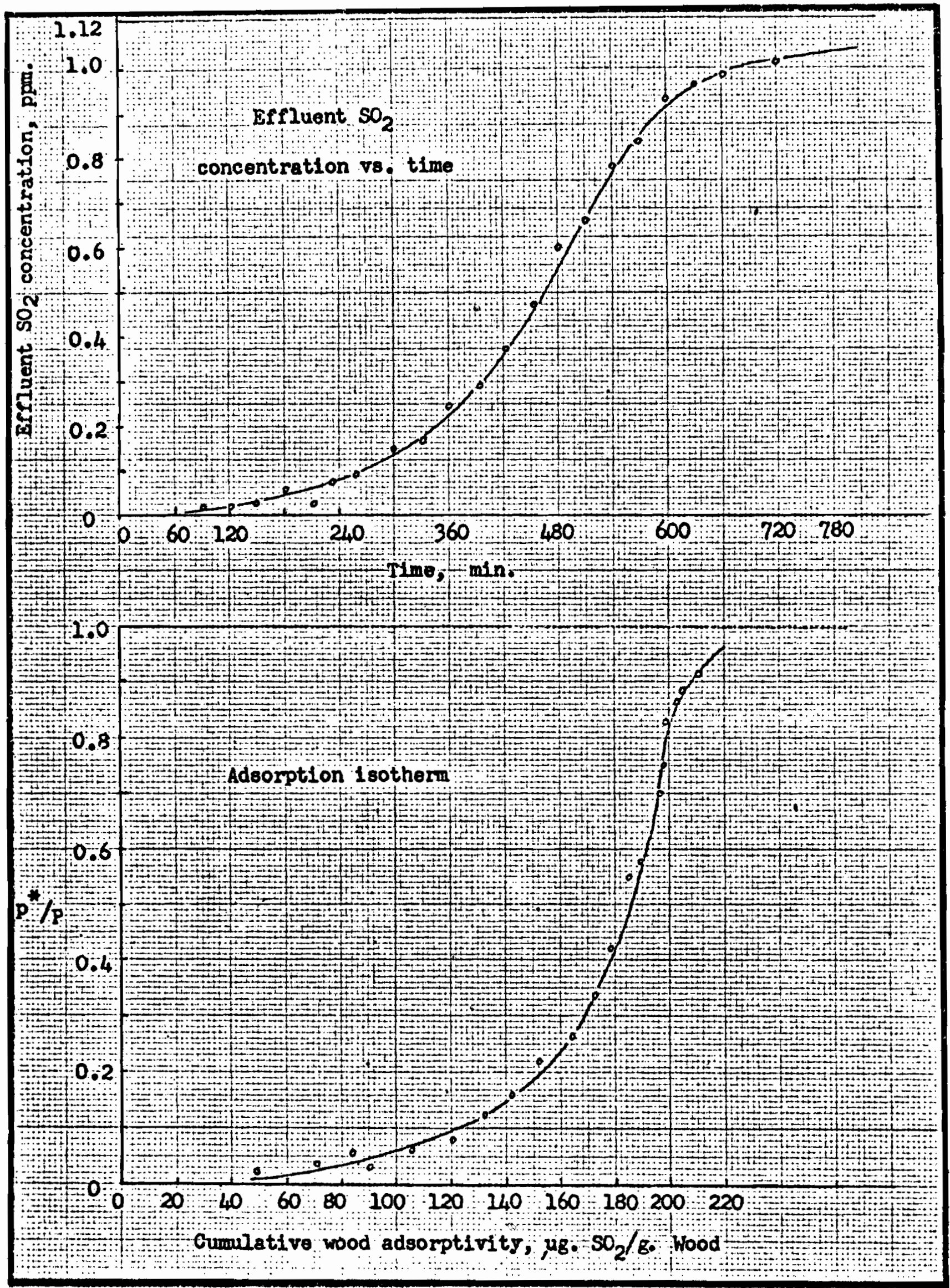

Fig. 12. The adsorption of $\mathrm{SO}_{2}$ on wood with $50 \% \mathrm{H}_{2} \mathrm{O}$ at an influent $\mathrm{SO}_{2}$ concentration of $1.12 \mathrm{ppm}$. 


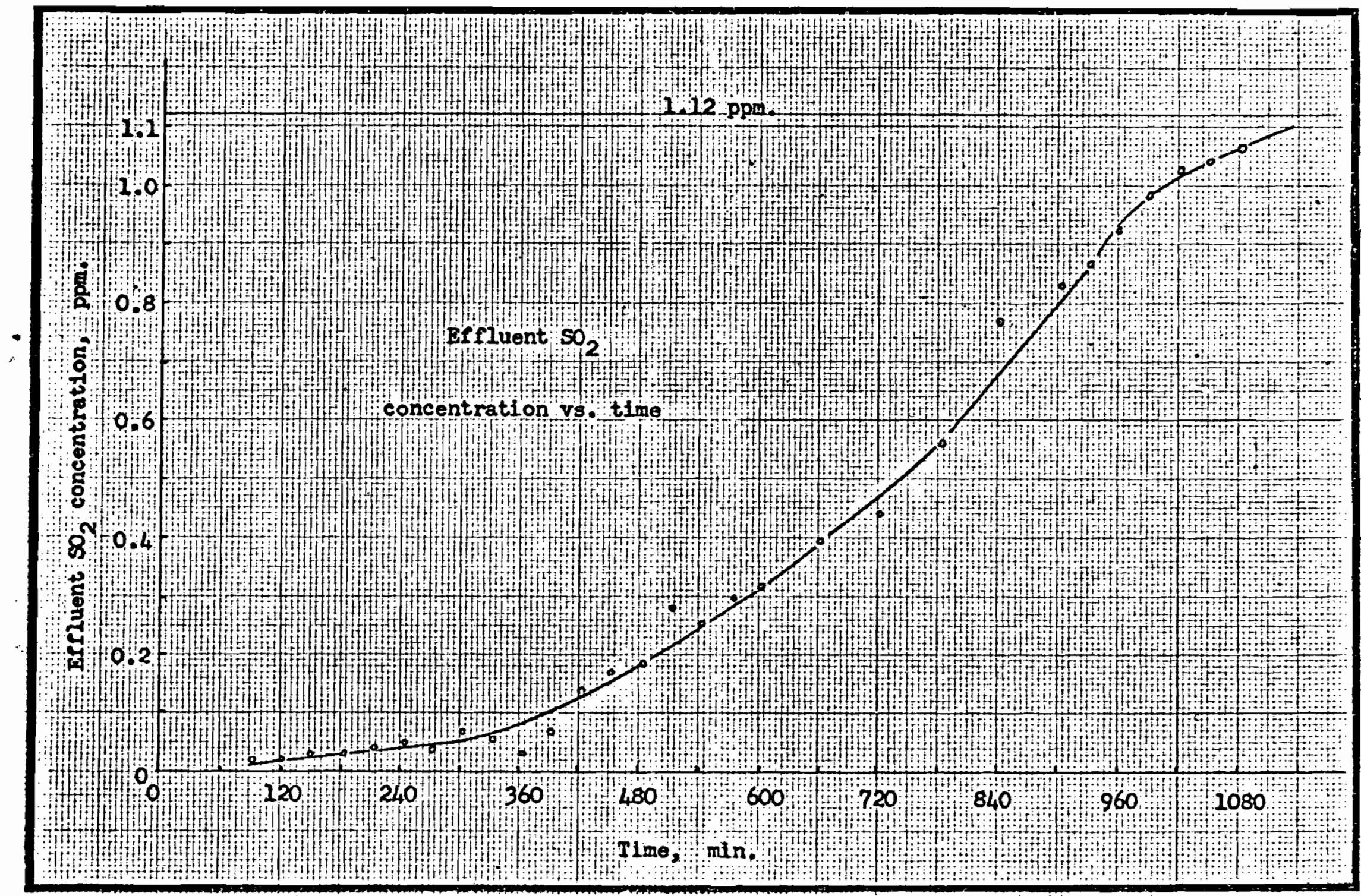

Fig. 13a. The adsorption of $\mathrm{SO}_{2}$ on wood with saturated molsture at an influent

$\mathrm{SO}_{2}$ concentration of $1.12 \mathrm{ppm}$. 


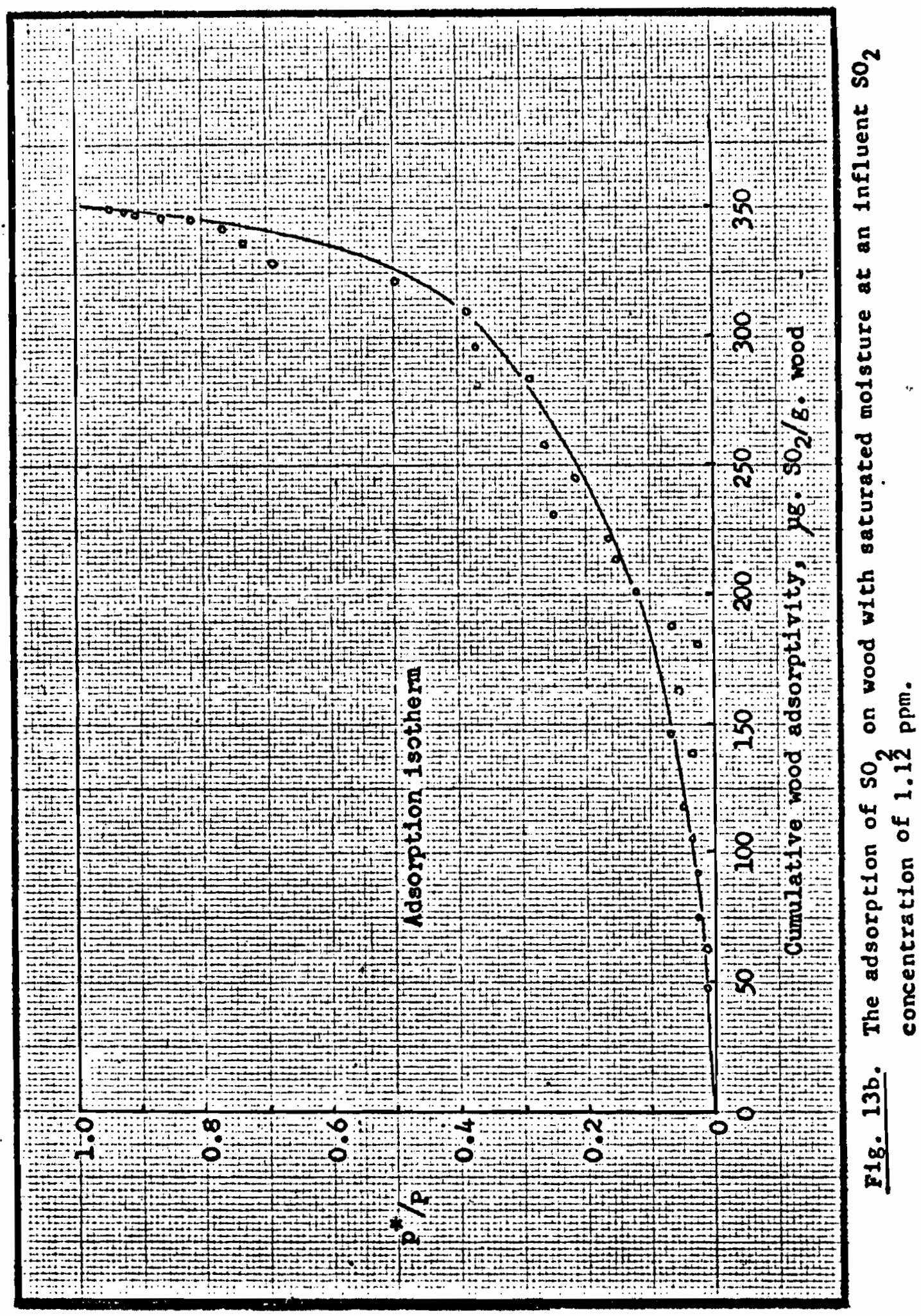




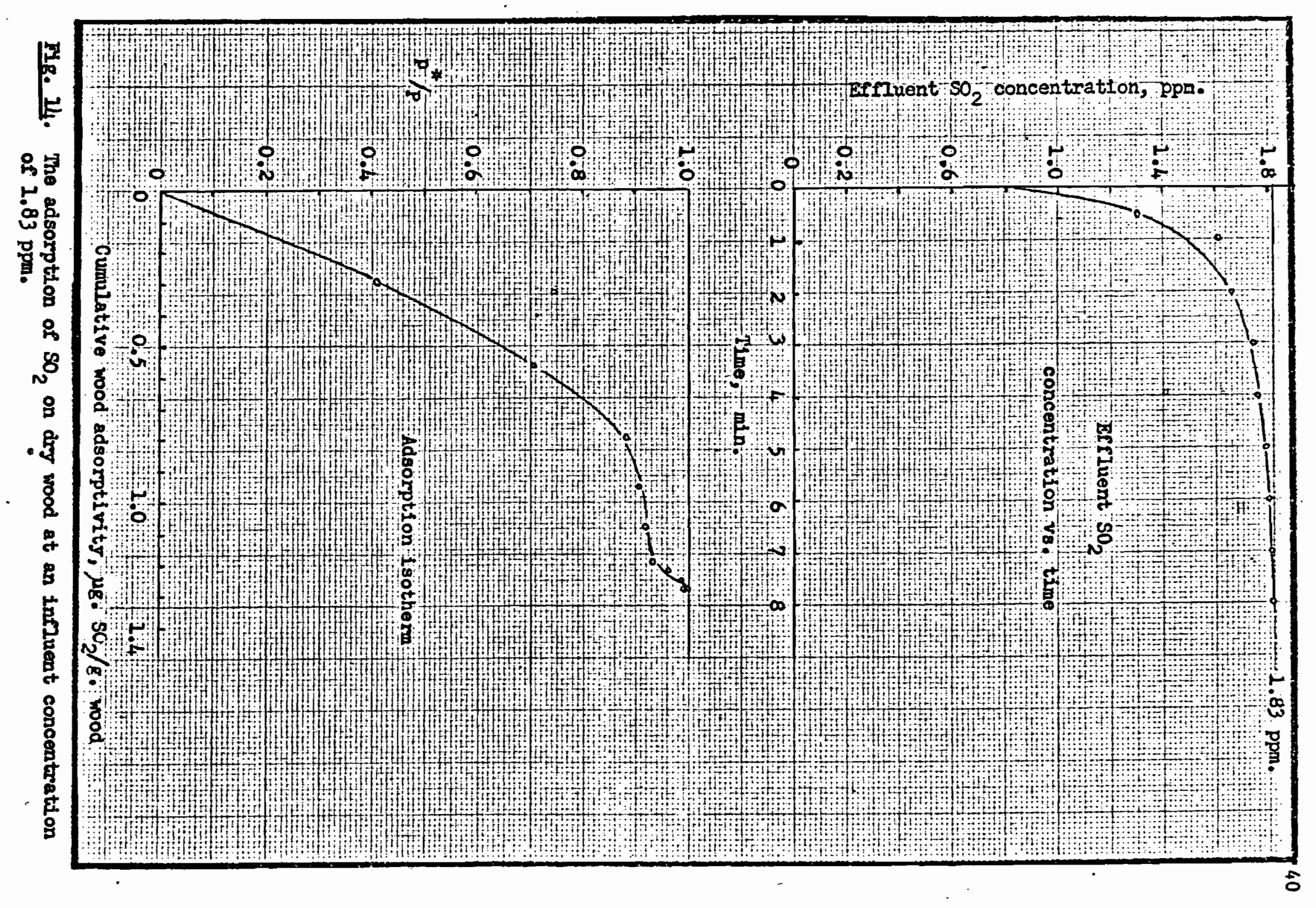




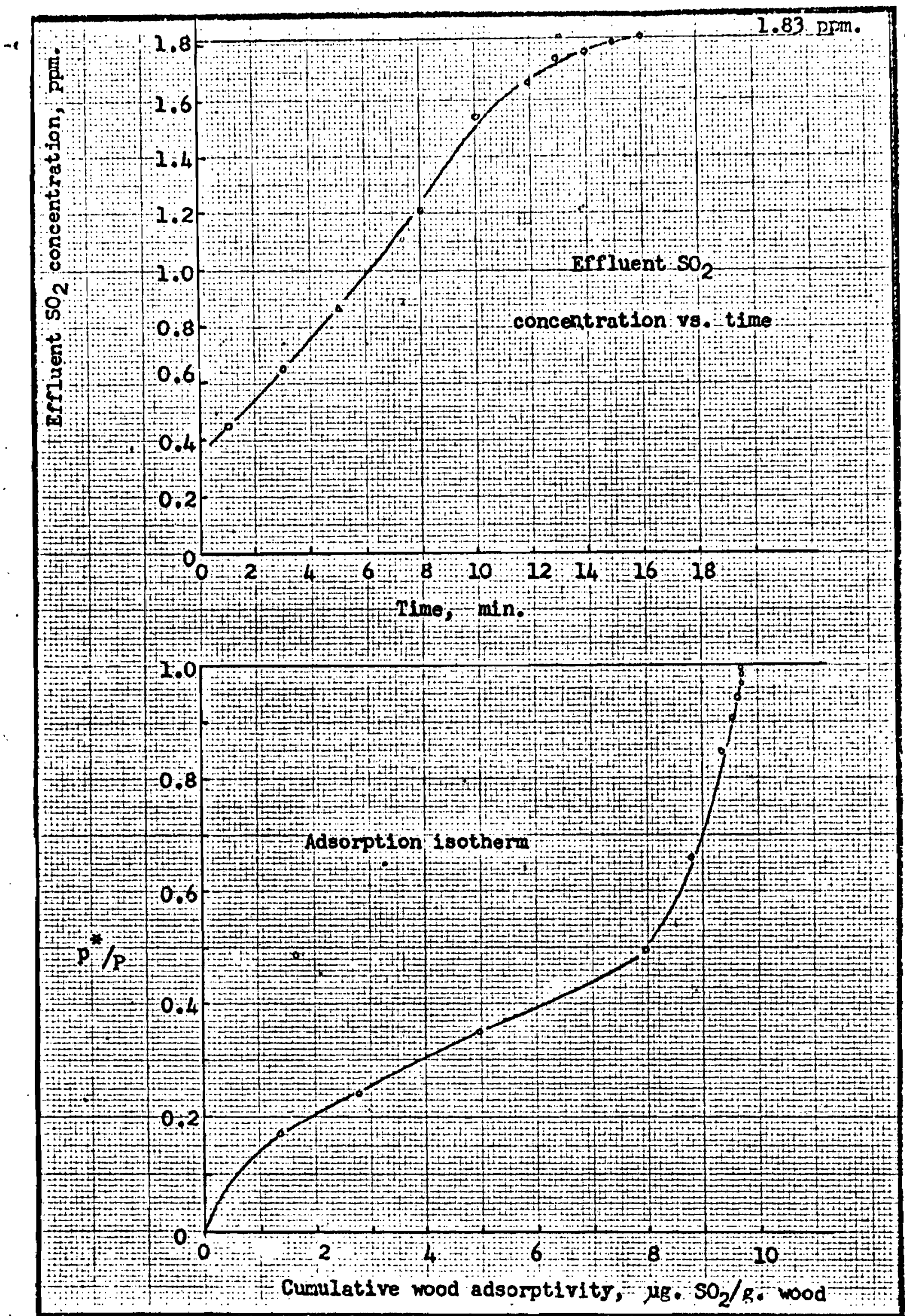




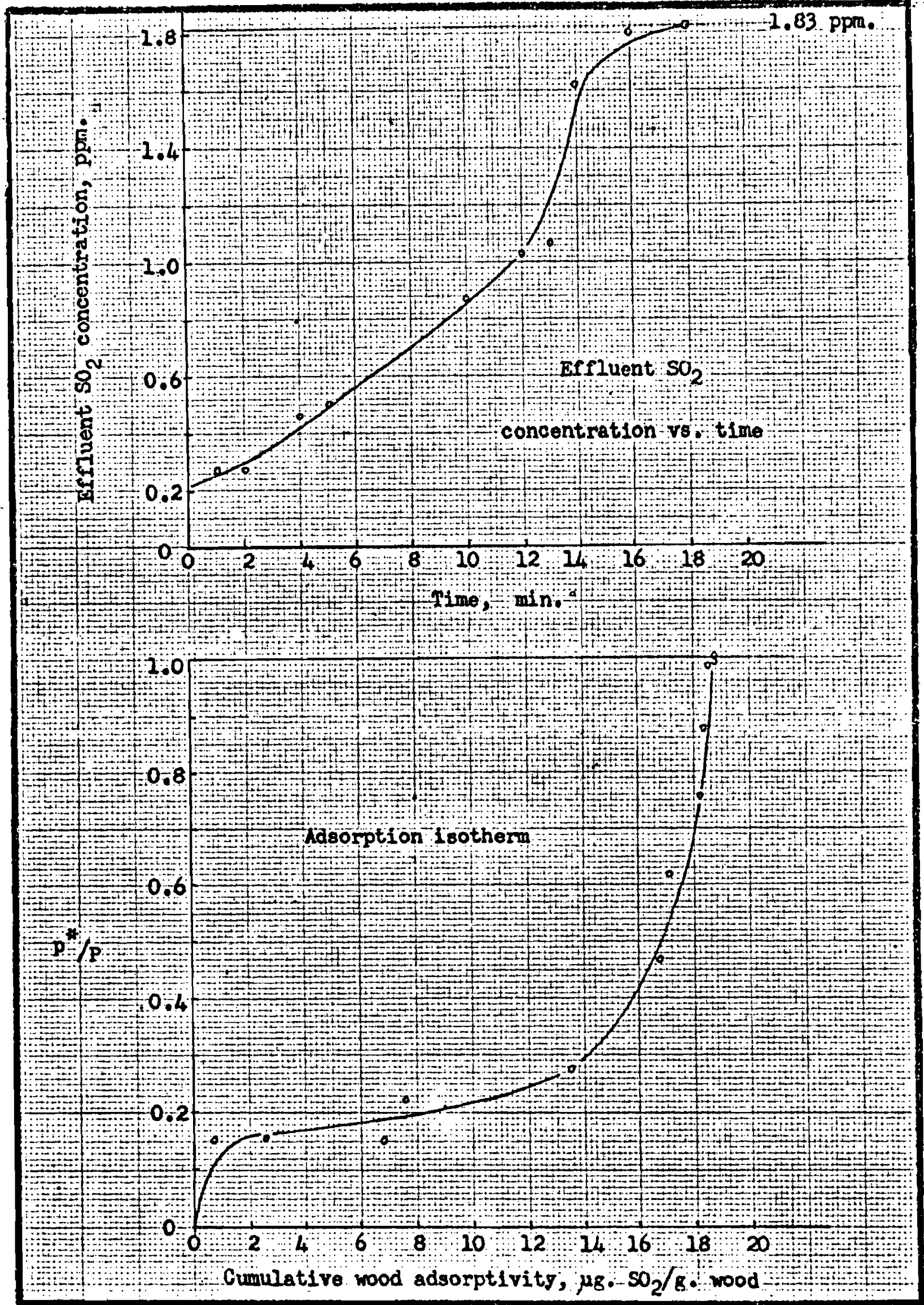

Fipe 16. The adsorption of $\mathrm{SO}_{2}$ on wood with $208 \mathrm{H}_{2} \mathrm{O}$ at an influent $\mathrm{SO}_{2}$ concentration of $1.83 \mathrm{ppm}$. 


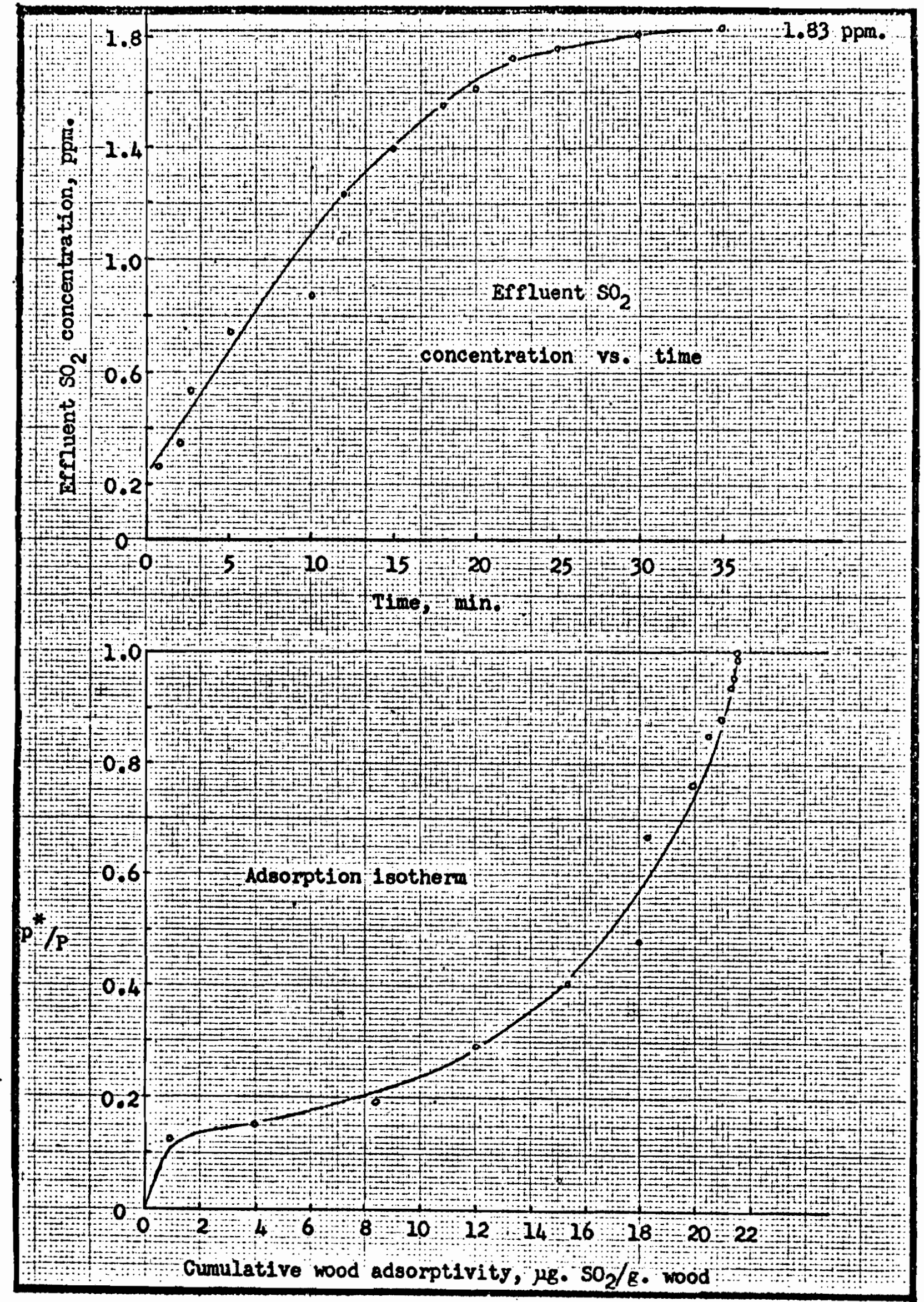




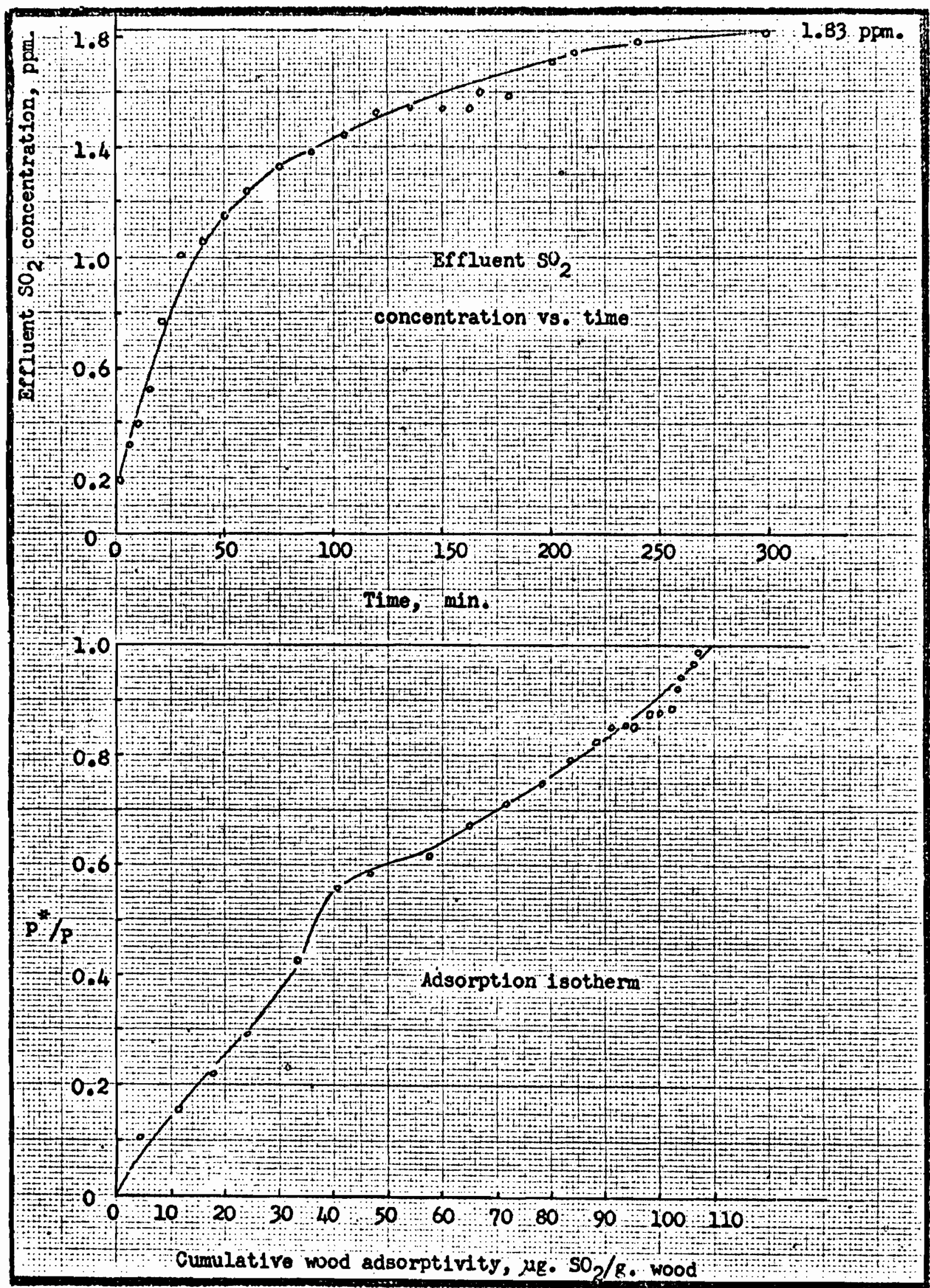

Fig. 18. The adsorption of $\mathrm{SO}_{2}$ on wood with saturated moisture at an Influent $\mathrm{SO}_{2}$ concentration of $1.83 \mathrm{ppm}$. 


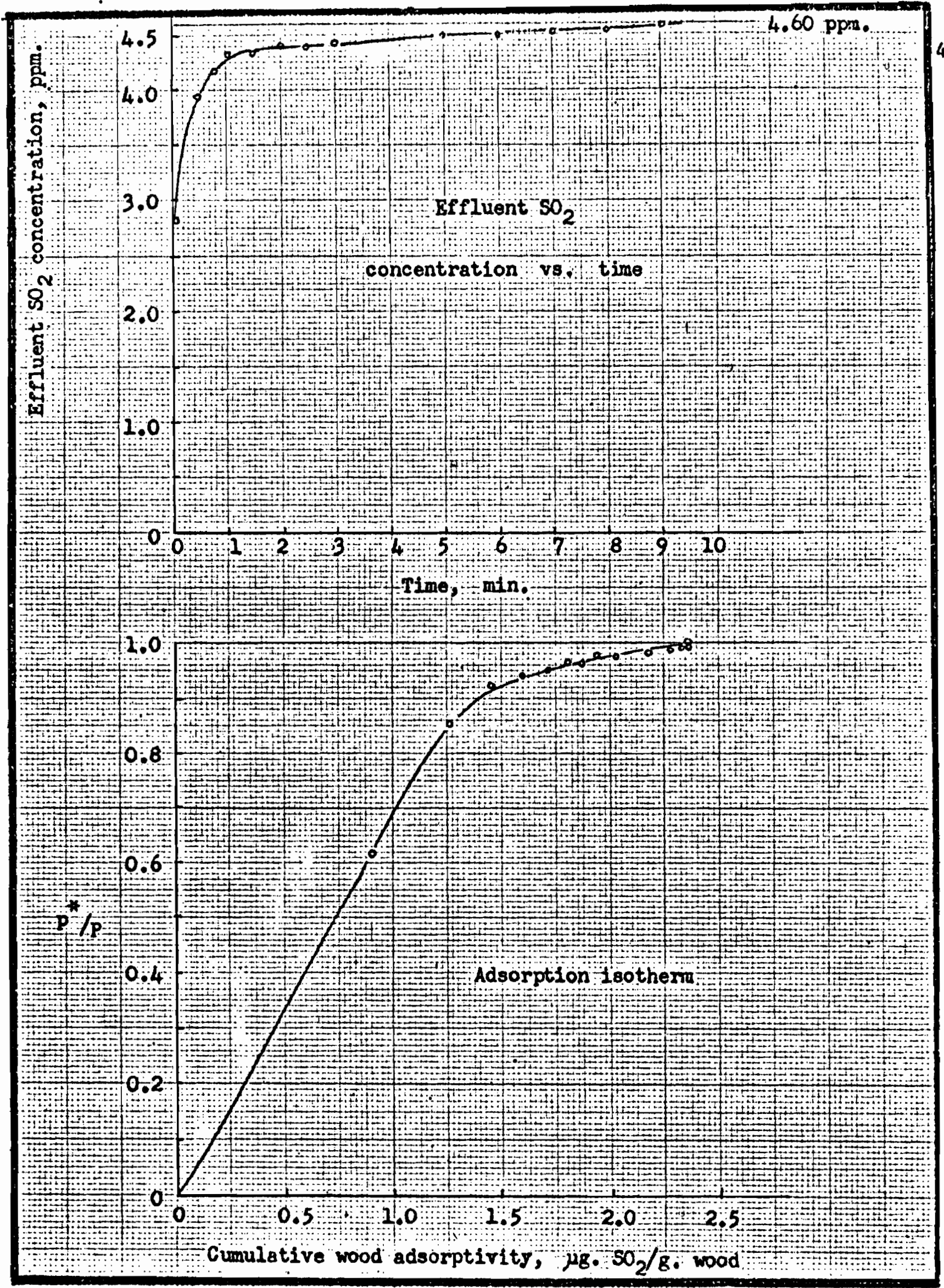




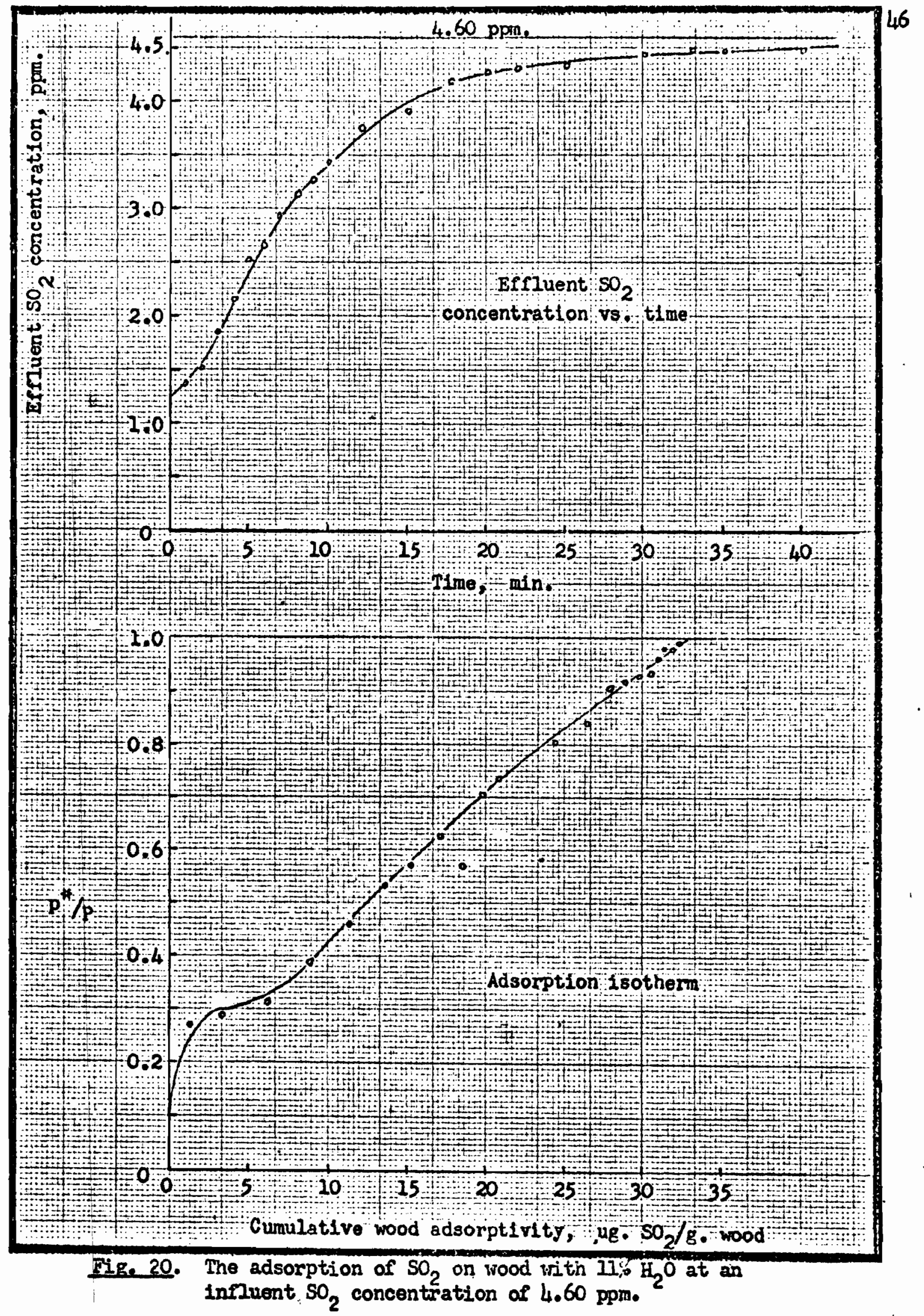


1

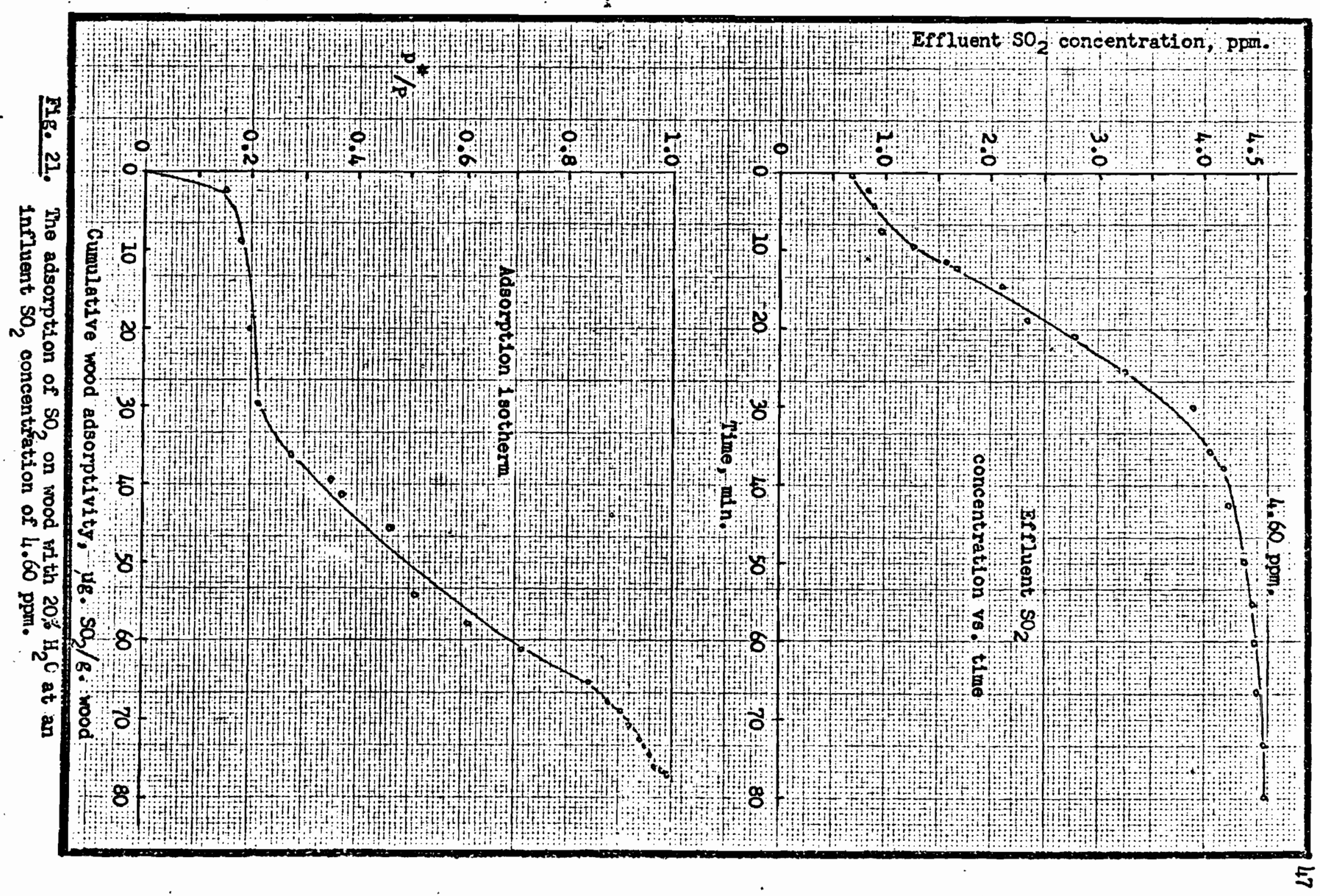




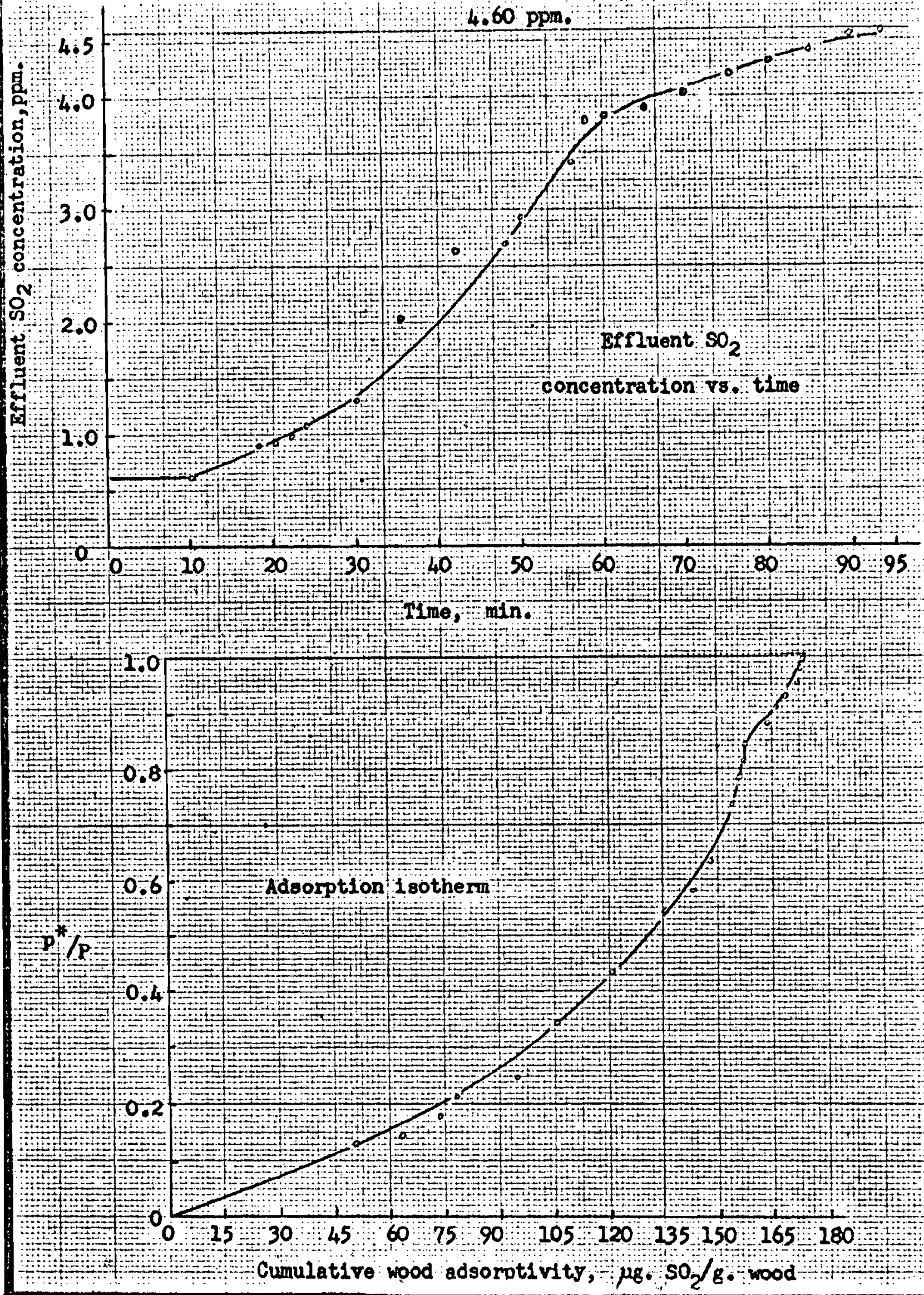

Fg. 22. The adsorption of $\mathrm{SO}_{2}$ on wood with $50,5 \mathrm{H}_{2} \mathrm{O}$ at an influent $\mathrm{SO}_{2}$ concentration of $4.60 \mathrm{ppm}$. 


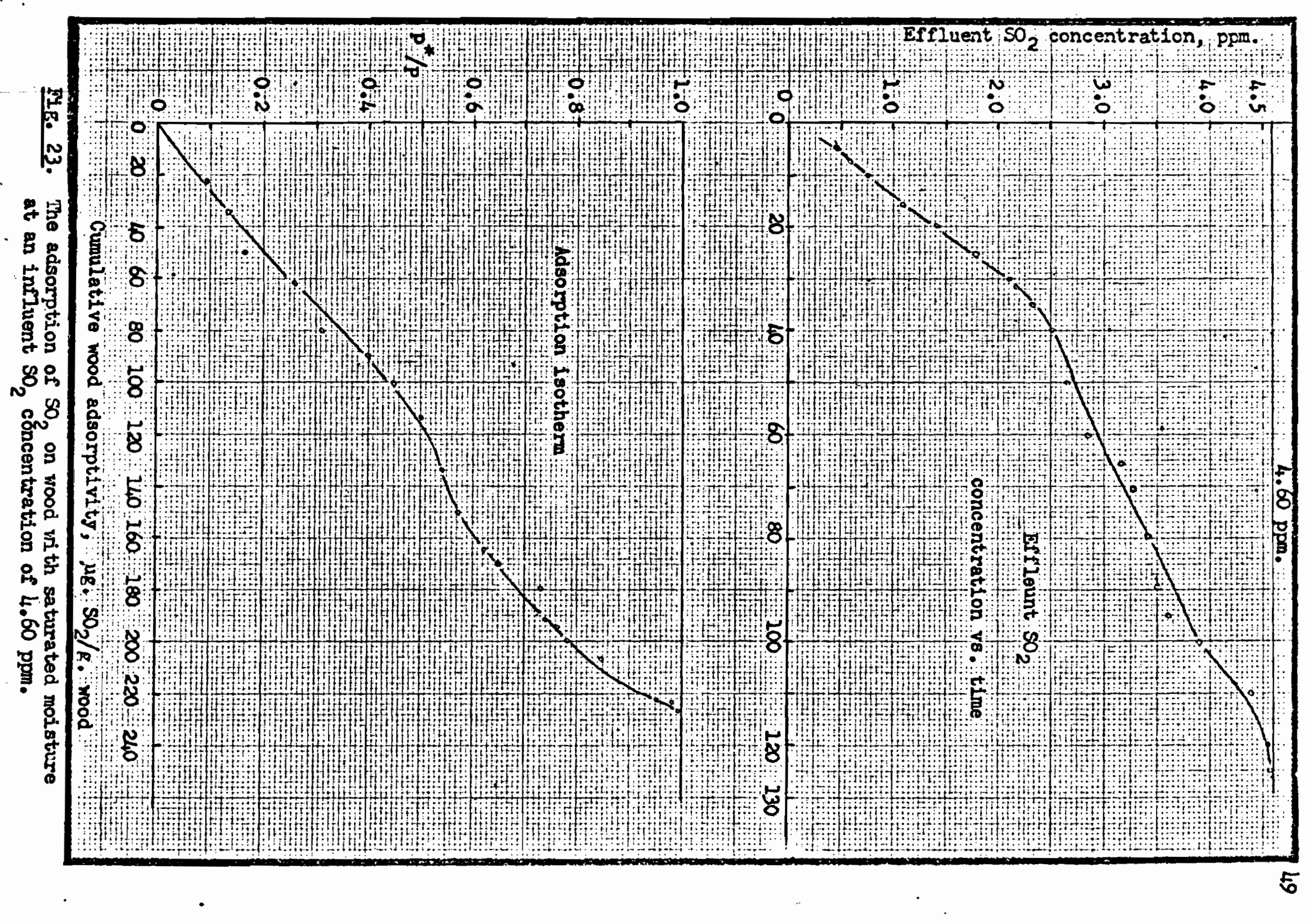




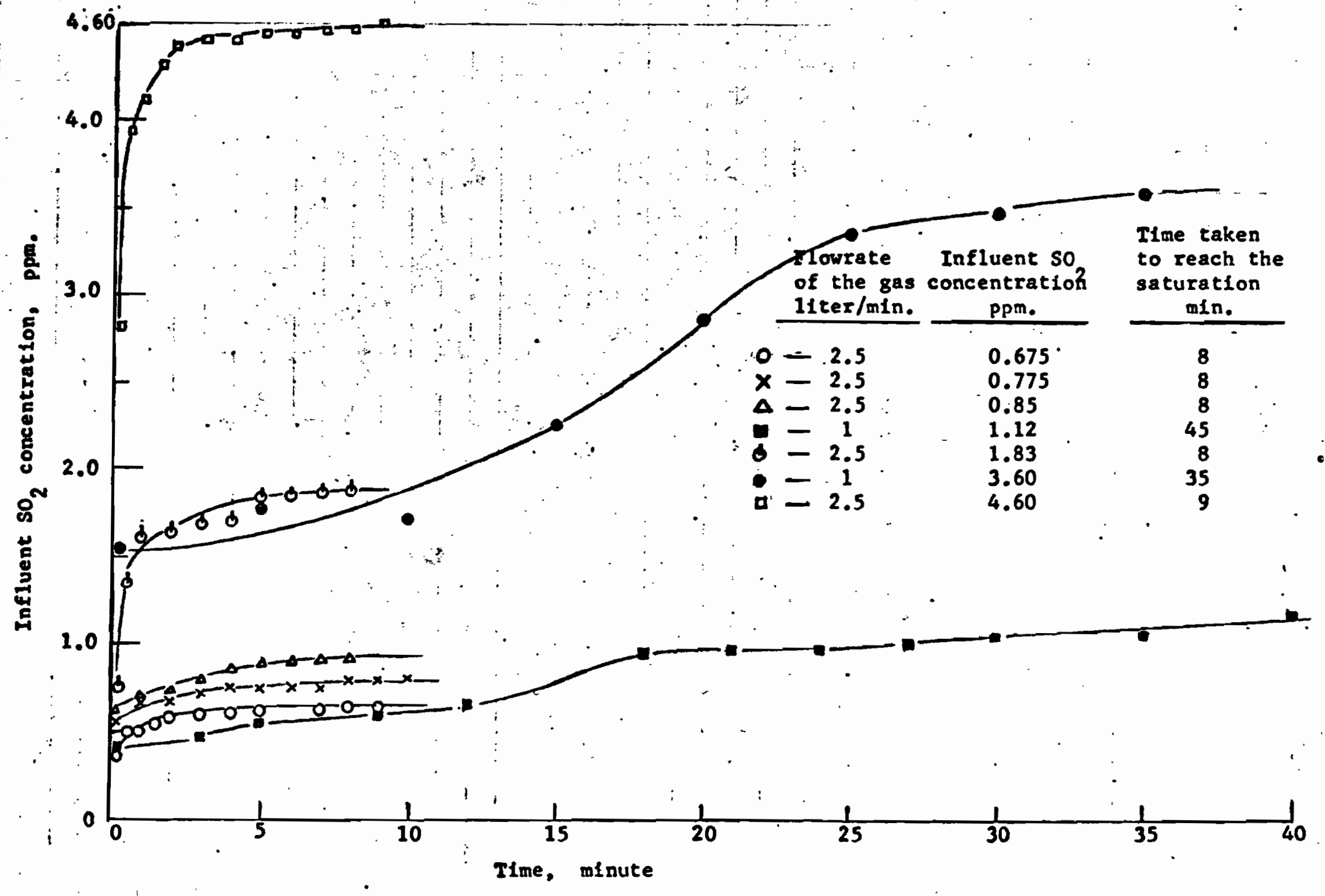

Plg. 24. Comparison of the saturation rate of sulfur dioxide on dry wood at different Influent $\mathrm{SO}_{2}$ concentrations 
tents of wood for influent $\mathrm{SO}_{2}$ concentrations of $1.12 \mathrm{ppm} ., 1.83$ ppm., and 4,60 ppm. are shown In Fig. 25 to 27 respectively. It was found that the higher the molsture content in the wood, the longer the time needed to reach eaturation for $\mathrm{SO}_{2}$ in the wood, At an influent $\mathrm{SO}_{2}$ concentration of 1.12 ppa., the saturation time of $\mathrm{SO}_{2}$ for dry wood was 45 minutes. This increased to 210 minutes for $11 \%$ moisture; to 240 minutes for $20 \%$; to 720 minutes for 50\%; and to 1080 minutes for the saturated wood. For an influent concentratIon of $1.83 \mathrm{ppm}$., the time it took to reach saturation was 8 minutes for dry wood; 16 minutes for $11 \%$; 18 minutes for $20 \%$; 35 minutes for $50 \%$; and 300 minutes for the saturated wood. For an influent $\mathrm{sO}_{2}$ concentration of 4.60 $\mathrm{ppm}$, the time taken to reach saturation was 9 minutes for dry wood; and Increased to 30 minutes for $11 \%$; to 80 minutes for 20\%; to 93 minutes for $50 \%$; and 125 minutes for the saturated wood.

4. For each of the three influent $\mathrm{SO}_{2}$ concentrations, Table VI to VIII give the adsorption efficiencies of the woodchips at 0 time, the 5 th minute, the 10th minute and the final wood adsorptivity at different moisture content of wood samples. For an Influent $\mathrm{SO}_{2}$ concentration of $1.1,2 \mathrm{ppm}$, the adsorption efficiency was $66 \%$ for the first minute of the experiment with dry wood; It decreased to $47.3 \%$ after 5 minutes; to $45.5 \%$ after 10 minutes; and the overall efficiency was $22.2 \%$. However, for the wood with molsture content the adsorption efficiencles reached $100 \%$ in the first minute and decreased slowly with respect to time. The overall adsorption efficlencles were 33.17 for $11 \%$ molsture wood; $42.5 \%$ for $20 \%$ wood; $64.4 \%$ for $50 \%$ wood; and $65.9 \%$ for saturated wood. For an Influent concentration of $1.83 \mathrm{ppm}$, the overall efficlencies were $7.34,34.1,48.4,32.8$ and 20.6 percent for dry wood, $11 \%$ molsture wood, 20\%, $50 \%$ and saturated wood respectively. For an Influent concentration of $4.60 \mathrm{ppm}$, the overall efficiencies were $5.7 \%, 18.9 \%, 22.8 \%$, 


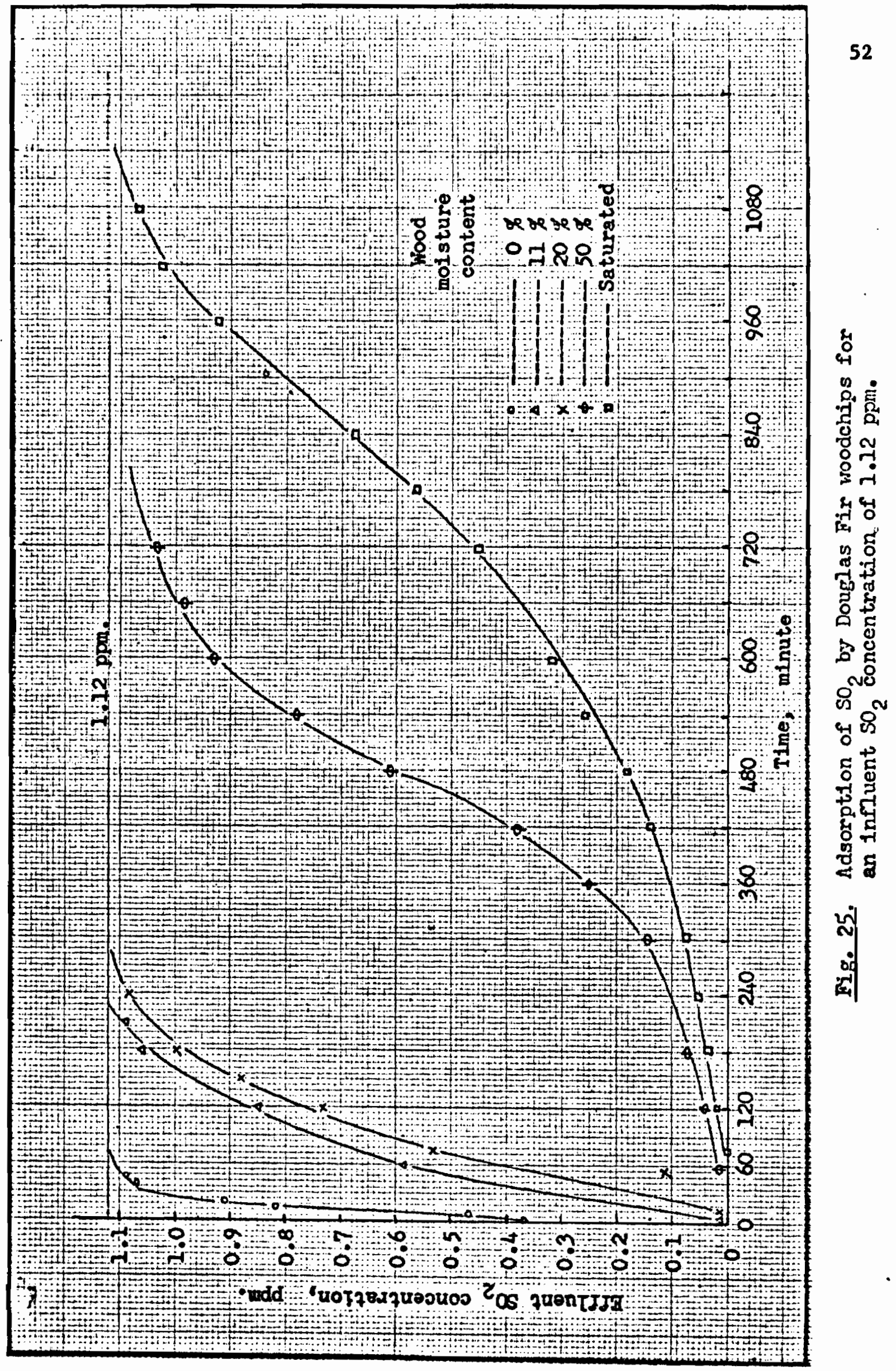




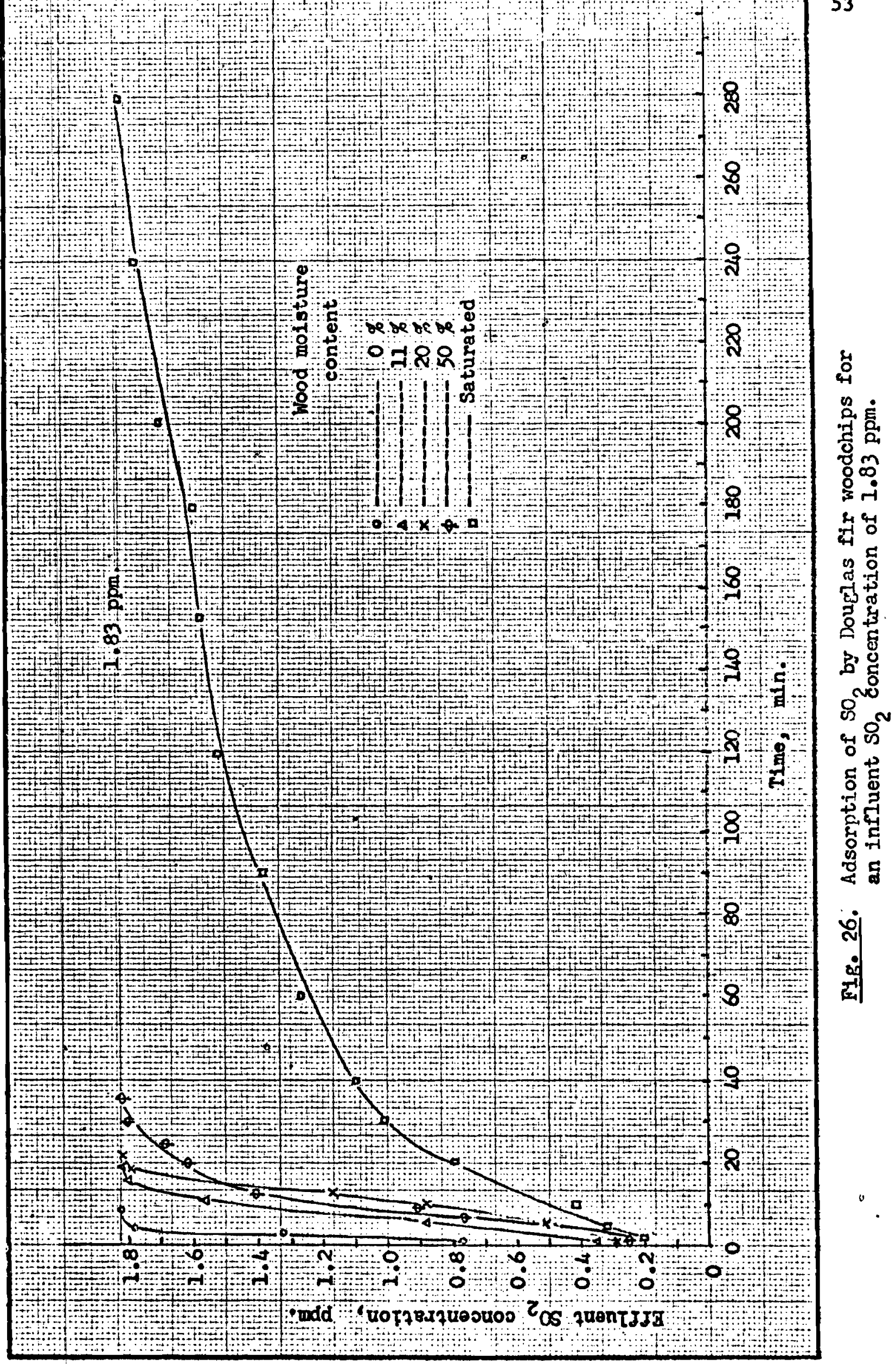




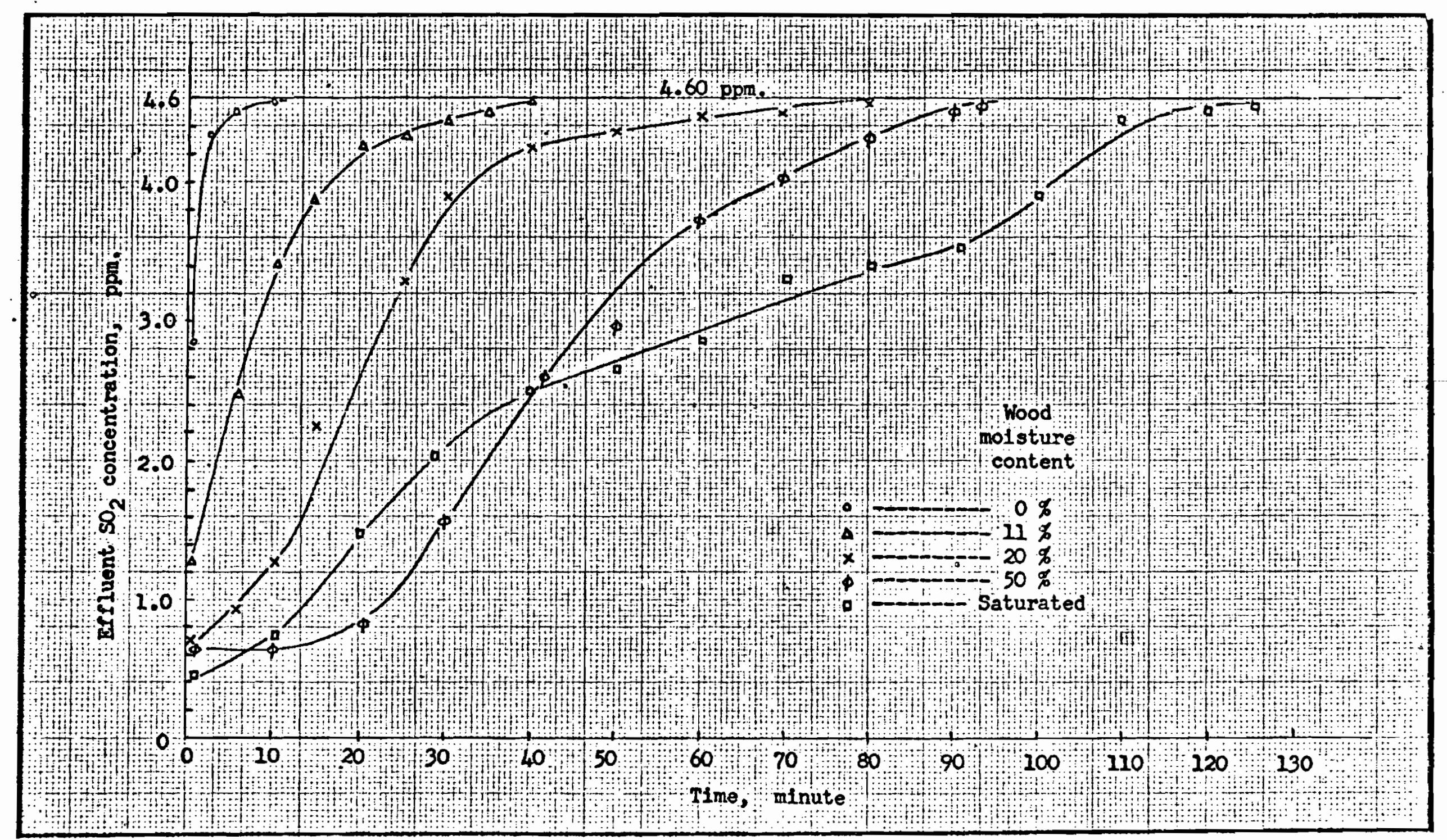

F1g. 27. Adsorption of $\mathrm{SO}_{2}$ by Douglas Fir woodchips for an influent $\mathrm{SO}_{2}$ concentration of $4.60 \mathrm{ppm}$. 
TABLE VI

ADSORPTION EFFICIENCIES AND ADSORPTIVITY OF WOOD FOR AN INFLUENT $\mathrm{SO}_{2}$ CONCENTRATION OF 1.12 PPM. $(2.94 \mu \mathrm{G} . / \mathrm{L}$.

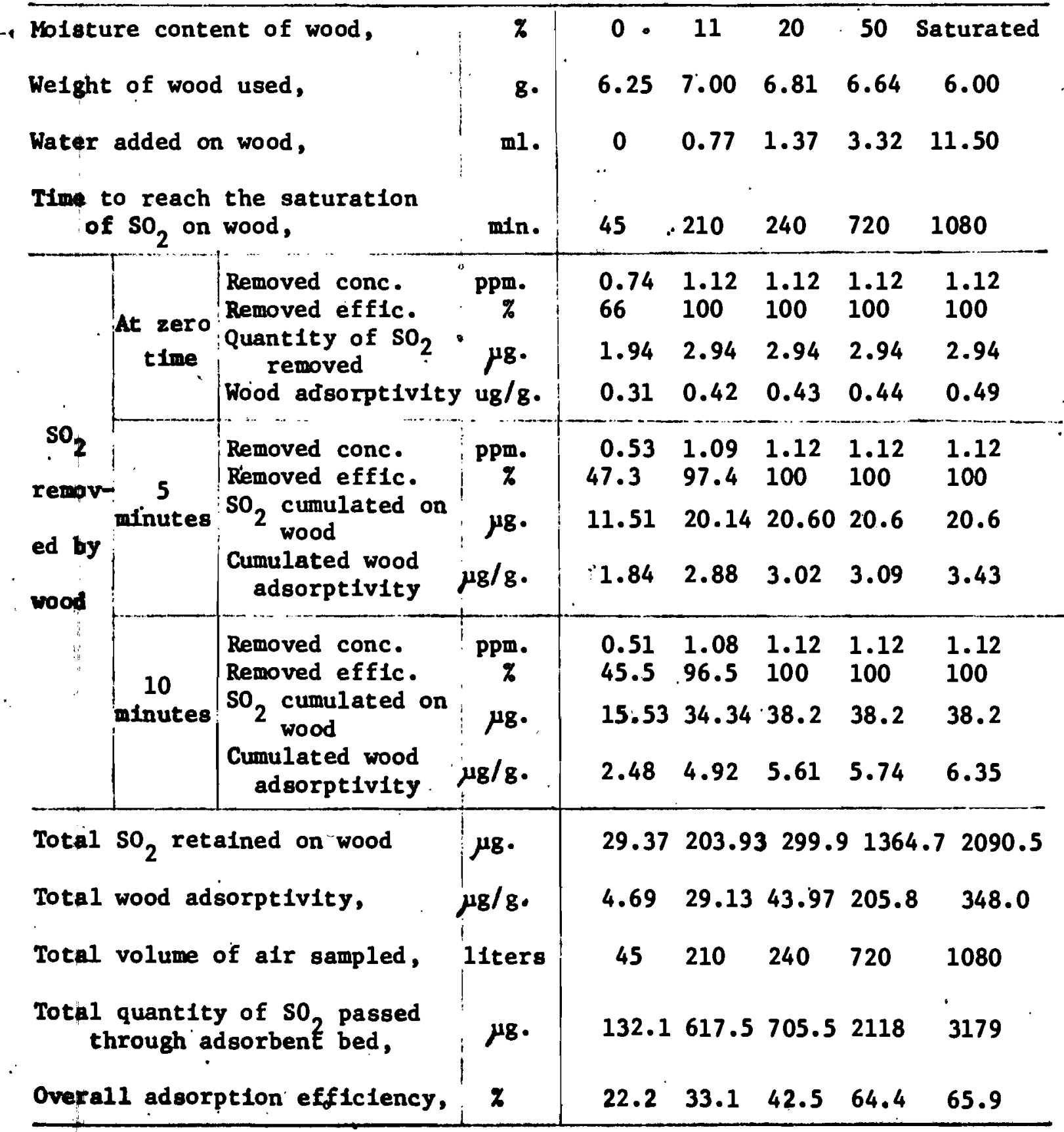


TABLE VII

ADSORPTION EFFICIENCIES AND ADSORPTIVITY OF WOOD FOR AN INFLUENT SO 2 CONCENTRATION OF 1.83 PPM. $(4.79 \mu \mathrm{G} . / \mathrm{L}$.

\begin{tabular}{|c|c|c|c|c|c|c|}
\hline \multirow{4}{*}{\multicolumn{2}{|c|}{\begin{tabular}{l|r} 
Molsture content of wood, & $\%$ \\
Weight of wood used; & $\mathrm{g}$. \\
Water added on wood, & $\mathrm{ml}$. \\
$\begin{array}{l}\text { Ts me to reach the saturation } \\
\text { of } \mathrm{SO}_{2} \text { on wood, }\end{array}$
\end{tabular}}} & \multirow{2}{*}{$\begin{array}{c}0 \\
6.15\end{array}$} & \multirow{2}{*}{6.83} & \multirow{2}{*}{$\begin{array}{l}20 \\
5.85\end{array}$} & \multicolumn{2}{|c|}{50 Saturated } \\
\hline & & & & & 6.72 & 7.00 \\
\hline & & 0 & 0.75 & 1.17 & 3.361 & 14.0 \\
\hline & & 8 & 16 & 18 & 35 & 300 \\
\hline \multirow{3}{*}{$\begin{array}{l}\text { At zero } \\
\text { time }\end{array}$} & \multirow{3}{*}{\begin{tabular}{l|c} 
Removed conc. & ppm. \\
Removed effic. & $\bar{z}$ \\
Quantity of $\mathrm{SO}_{2}$ & $\mu \mathrm{g}$. \\
$\quad$ removed & \\
Wood adsorptivity $\mu \mathrm{g} / \mathrm{g}$.
\end{tabular}} & $\begin{array}{l}1.07 \\
58.7\end{array}$ & $\begin{array}{l}1.50 \\
82.0\end{array}$ & $\begin{array}{l}1.55 \\
84.7\end{array}$ & $\begin{array}{l}1.58 \\
86.3\end{array}$ & $\begin{array}{l}1.63 \\
89.1\end{array}$ \\
\hline & & 1.76 & 9.83 & 5.07 & 5.18 & 26.7 \\
\hline & & 0.29 & 1.37 & 0.87 & 0.77 & 3.79 \\
\hline requoved 5 & \multirow{3}{*}{ 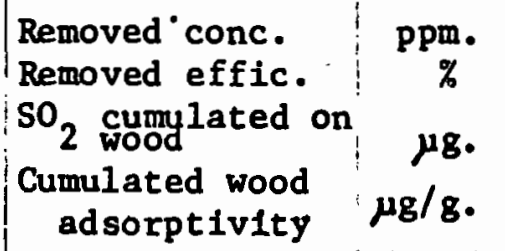 } & $\begin{array}{l}0.05 \\
2.8\end{array}$ & $\begin{array}{l}0.94 \\
51.3\end{array}$ & $\begin{array}{l}1.33 \\
72.7\end{array}$ & $\begin{array}{l}1.08 \\
59.0\end{array}$ & $\begin{array}{l}1.52 \\
83.1\end{array}$ \\
\hline minutes & & 7.63 & .52 .0 & 79.3 & 101.6 & 76.5 \\
\hline oy & & 1.24 & 7.61 & 13.54 & 15.11 & 10.84 \\
\hline \multirow{3}{*}{$\begin{array}{l}10 \\
\text { minutes }\end{array}$} & \multirow{3}{*}{$\begin{array}{l}\text { Removed conc. } \\
\text { Removed effic. } \\
\text { som. } \\
\text { so }_{2} \text { cumulated on } \\
\begin{array}{l}\text { wood } \\
\text { Cumulated wood } \\
\text { adsorptivity. }\end{array}\end{array}$} & $\begin{array}{l}0 \\
0\end{array}$ & $\begin{array}{l}0.26 \\
14.2\end{array}$ & $\begin{array}{l}0.96 \\
52.5\end{array}$ & $\begin{array}{l}0.95 \\
51.9\end{array}$ & $\begin{array}{l}1.42 \\
77.6\end{array}$ \\
\hline & & 7.73 & 63.39 & 98.13 & 114.0 & 123.0 \\
\hline & & 1.26 & 9.38 & 16.79 & 17.96 & 17.58 \\
\hline \multirow{2}{*}{\multicolumn{2}{|c|}{$\begin{array}{l}\text { Total } \mathrm{SO}_{2} \text { retalned on wood, } \\
\text { Total wood adsorptivity, }\end{array}$}} & 7.73 & 65.26 & 107.24 & \multicolumn{2}{|c|}{4143.23745 .15} \\
\hline & & 1.26 & 9.56 & 18.35 & 21.35 & 106.38 \\
\hline Total volume & f air sampled, & 21.88 & 40 & 46.3 & 91.3 & 756.3 \\
\hline \multicolumn{2}{|c|}{$\begin{array}{l}\text { Totail quanty of } \mathrm{SO}_{2} \text { passed } \\
\text { through adsorbent bed, }\end{array}$} & 105.3 & 191.9 & 221.9 & $437 \cdot 5$ & 3623.0 \\
\hline \multicolumn{2}{|c|}{ Overall adsorption efficiency. } & 7.34 & 34.1 & 48.4 & 32.8 & 20.6 \\
\hline
\end{tabular}


TABLE VIII

ADSORPTION EFFICIENCIES AND ADSORPTIVTTY OF WOOD FOR AN INFLUENT SO CONGENTRATION OF 4.60 PPM $(12.05 \mu \mathrm{G} . / \mathrm{L}$.

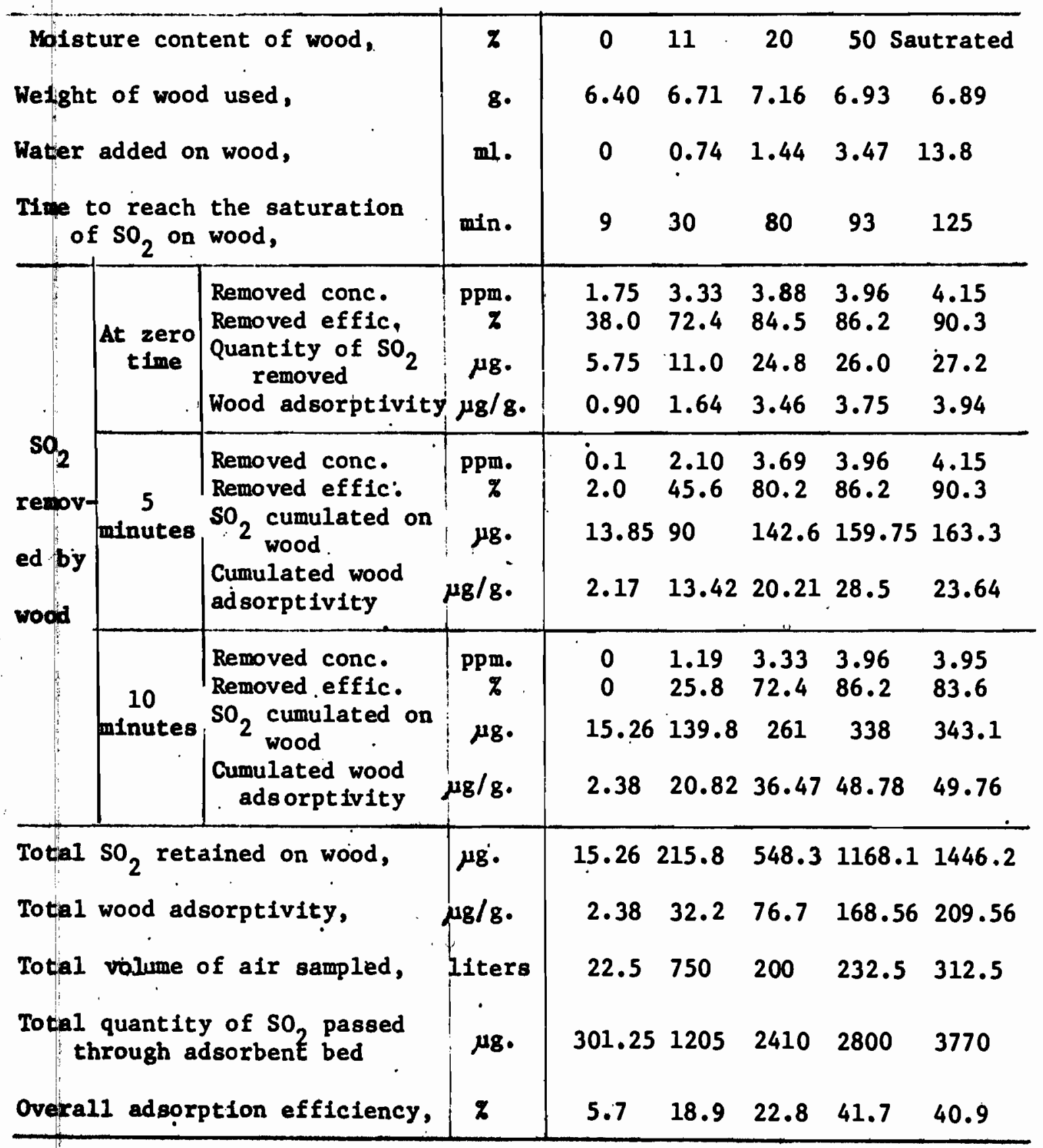


41.7\% and $40.9 \%$ for dry wood, $11 \%, 20 \%, 50 \%$ and saturated wood respectively. It is very clear that the adsorptvity of $\mathrm{SO}_{2}$ on wood increased with increasing moisture content in wood.

5. For an influent $\mathrm{SO}_{2}$ concentration of $1.12 \mathrm{ppm}$., the $\mathrm{SO}_{2}$ retained in wood ranged from $29.37 \mu g$. of $\mathrm{SO}_{2}$, in the dry wood to $203.93 \mu \mathrm{g}$. In $11 \%$ wood to $299.9 \mu 8$. In $20 \%$; $1364.7 \mu \mathrm{g}$. In $50 \%$; and to $2090.5 \mu \mathrm{g}$. in the moiskure saturated wood. For an influent $\mathrm{SO}_{2}$ concentration of $1.83 \mathrm{ppm}$., the $\$ \mathrm{O}_{2}$ adsorbed in wood ranged from $7.734 \mu \mathrm{g}$. for the dry wood to 65.26 $\mu \mathrm{g}$. for $11 \%$ wood; to $107.24 \mu \mathrm{g}$. for $20 \%$; to $143.23 \mu \mathrm{g}$. for $50 \%$; to 745.15

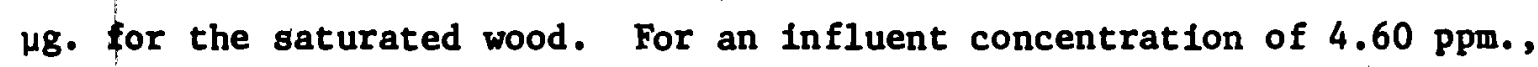
$\mathrm{SO}_{2}$ adsorbed in wood were $15.26 \mu \mathrm{g}$. for the dry wood; $215.8 \mu \mathrm{g}$. for $11 \%$; $548.3 \mu \mathrm{g}$. for $20 \%$; $1168.13 \mu \mathrm{g}$. for $50 \%$; and $1446.2 \mu \mathrm{g}$. for the saturated wood. The influence of moisture content on the adsorption of sulfur dioxide on wood at the different influent $\mathrm{SO}_{2}$ concentrations in shown in Fig. 28 .

6. The proportionality constants " $K$ " and " $n$ " In the Freundlich equation obtained by substituting the experimental data into the equation are presented in Table IX. For an Influent $\mathrm{SO}_{2}$ concentration of $1.12 \mathrm{ppm}$. , the values of $-{ }^{\prime \prime} \mathrm{x}$ " fncreased from 1.1 for the dry wood to 235.0 for the moisture saturated wood. However, the constant " $n$ " decreased from 1.38 to 0.373 . For an Influent concentration of $1.83 \mathrm{ppm}$., the constant " $\mathrm{K}$ " Increased from 0.13 to 14.0 while the values of " $n$ " decreased from 1.47 to 0.82 . And for an Influent concentration of $4.60 \mathrm{ppm}$. , the constant "K" Increased from 0.1 for dry wood to 33.0 for the saturated wood while the constant "n" decreased from 1.13 down to 0.777 . Referring to the above data, the Freundlich adsorption 1sotherms are plotted for the sulfur dioxide on three different influent $\mathrm{SO}_{2}$. concentrations in $108-108$ papers as shown in $F 1_{8} .29$ to 31. 


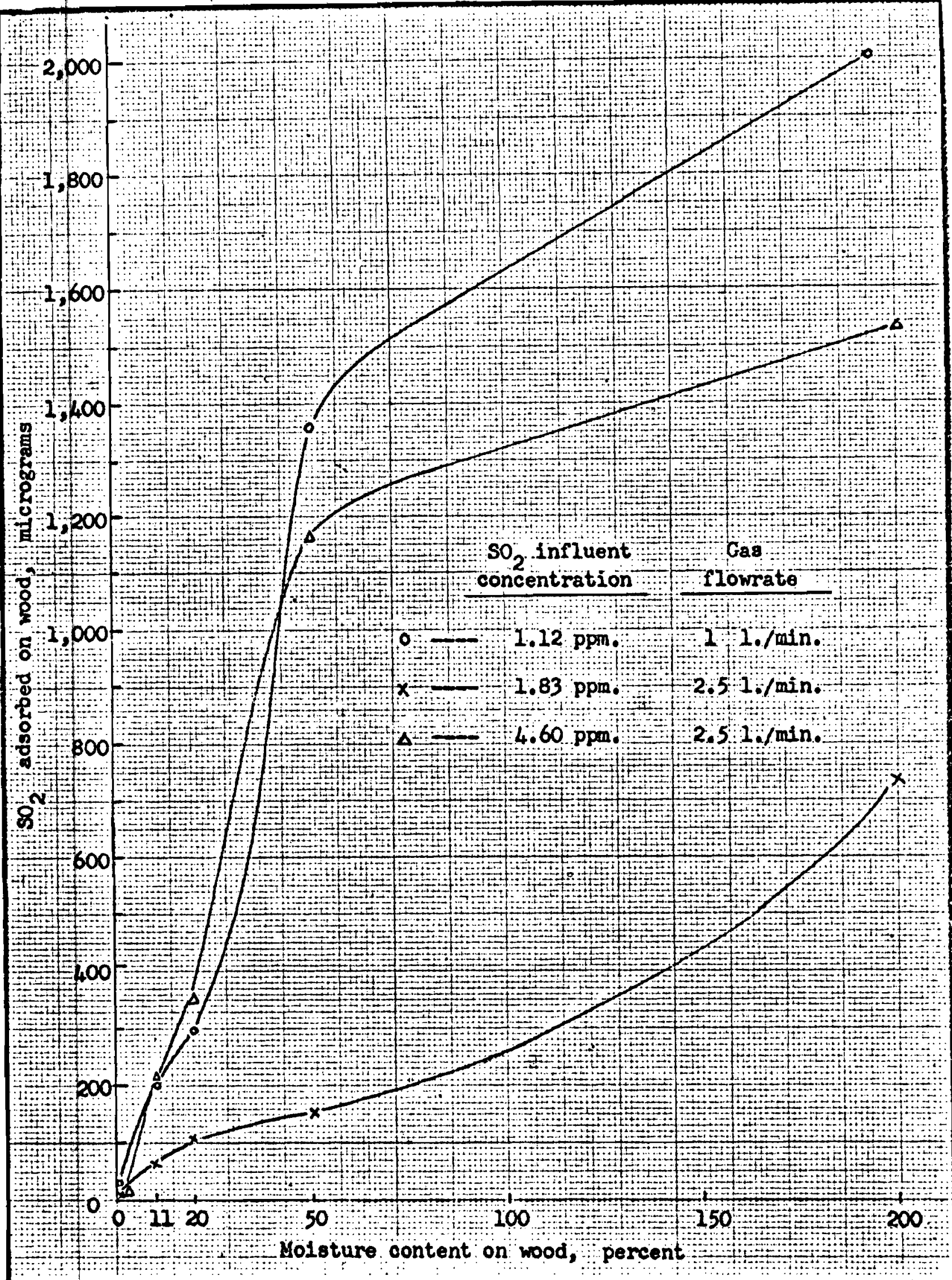

Fig. 28. Influence of moisture on the adsorption of $\mathrm{SO}_{2}$ by wood at the different influent $\mathrm{SO}_{2}$ concentrations. 
TABLE IX

LIST OF THE VALUES OF THE CONSTANTS " $\mathrm{k}$ " AND " $n$ " IN FREUNDLICH EQUATION FOR THE ADSORPTION OF SULFUR DIOXIDE ON DOUGLAS FIR WOODCHIPS

\begin{tabular}{|c|c|c|c|c|c|c|}
\hline \multirow{3}{*}{$\begin{array}{l}\text { Percent of } \\
\text { molpture on } \\
\text { prood }\end{array}$} & \multicolumn{6}{|c|}{ Influent $\mathrm{SO}_{2}$ concentration, ppm. } \\
\hline & \multicolumn{2}{|c|}{1.12} & \multicolumn{2}{|c|}{1.83} & \multicolumn{2}{|c|}{4.60} \\
\hline & $\mathbf{R}$ & $\mathbf{n}$ & $\mathbf{R}$ & $\mathbf{n}$ & $\mathbf{K}$ & $\mathbf{n}$ \\
\hline 0 & 1.1 & 1.38 & 0.13 & 1.47 & 0.10 & 1.13 \\
\hline 11 & 14.5 & 0.64 & 1.6 & 1.12 & 0.76 & 1.55 \\
\hline 20 & 34.2 & 0.184 & 6.3 & 1.0 & 15.5 & 0.654 \\
\hline 50 & 160.0 & 0.388 & 9.0 & 0.82 & 59.0 & 0.514 \\
\hline $\begin{array}{c}200 \\
\text { (Sacurated) }\end{array}$ & 235.0 & 0.373 & 14.0 & 1.3 & 33.0 & 0.777 \\
\hline
\end{tabular}




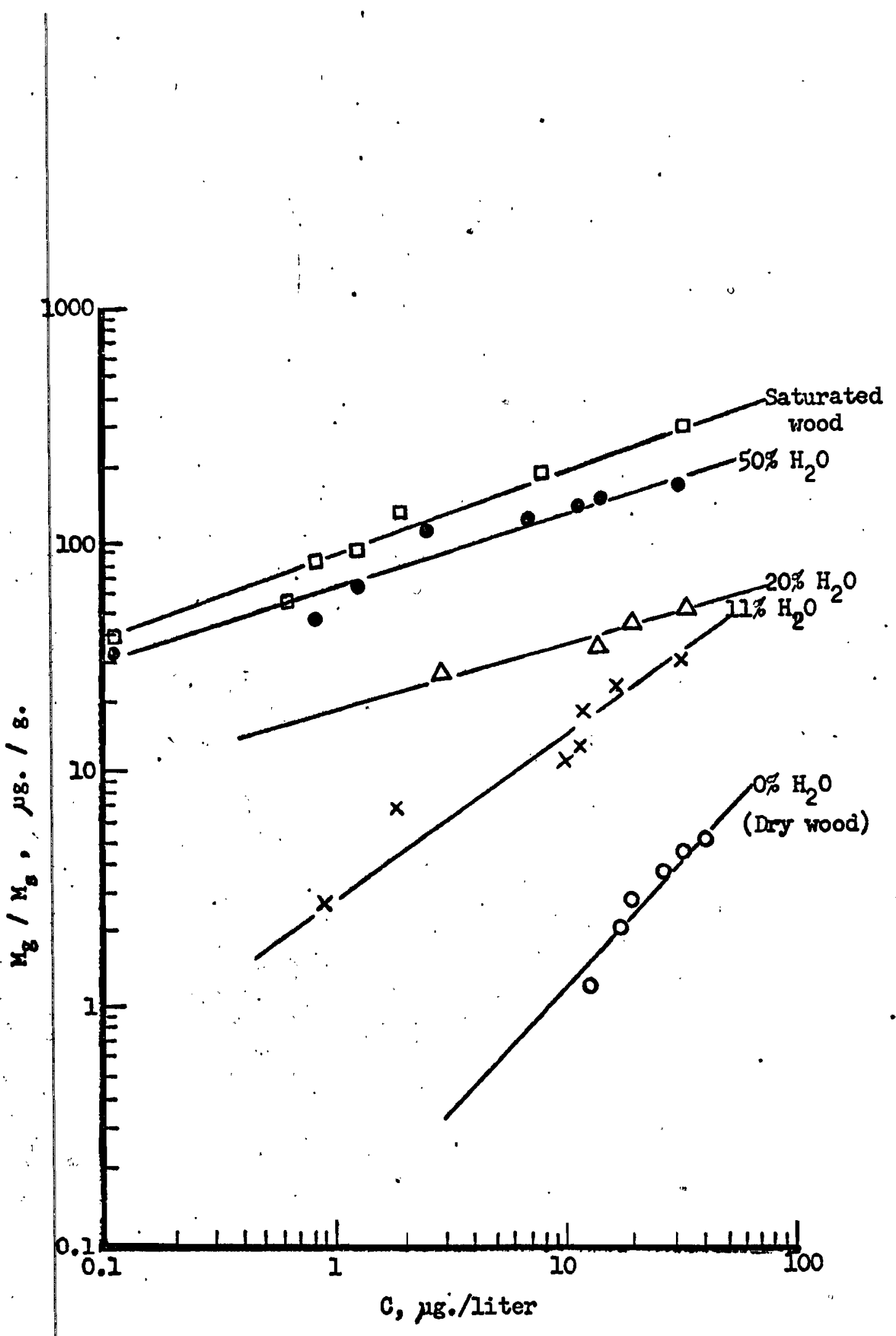

Fig. 29. Freundlich Adsorption Isotherm for Sulfur Dioxide on wood for an Influent $\mathrm{SO}_{2}$ Concentration of $1.12 \mathrm{ppm}$. 


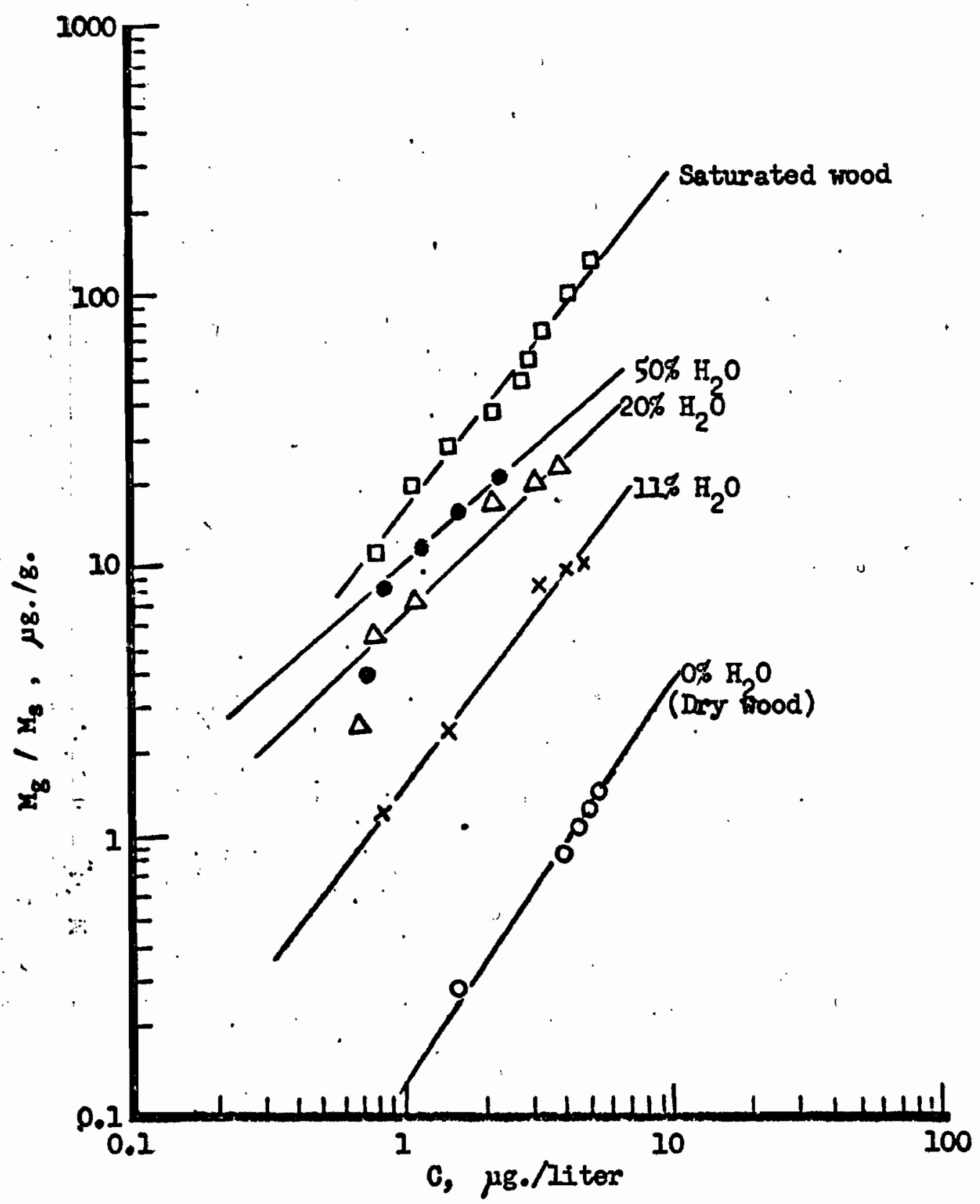

Fr. 30. Freundlich Adsorption Isotherm for Suflur Dioxide on rood for an Influent. $\mathrm{SO}_{2}$ Concentration of $1.83 \mathrm{ppm}$. 


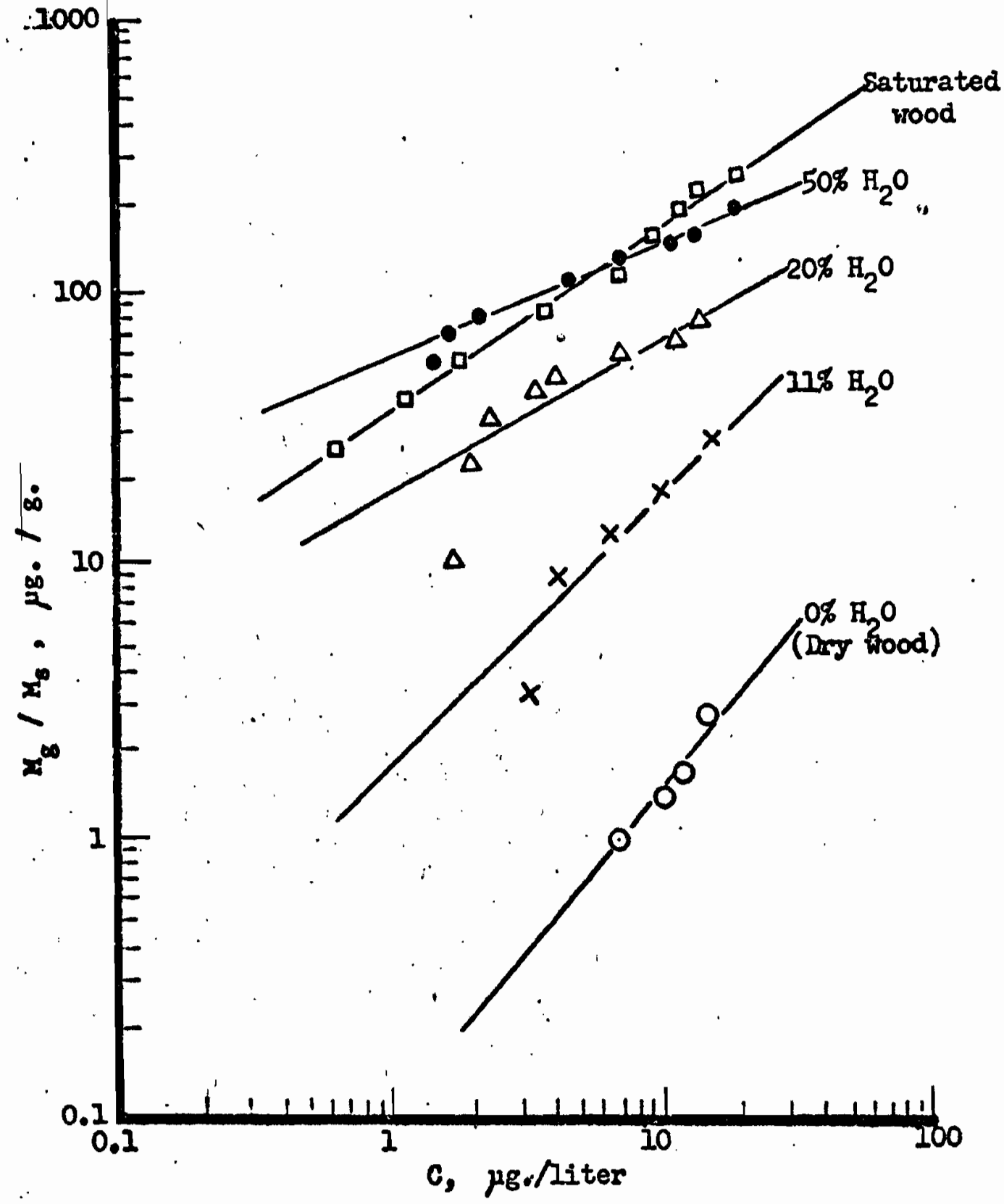

F1.31. Freundlich Adsorption Isotherm for Sulfur Dioxide on wood for an Influent $\mathrm{SO}_{2}$ Concentration of $4.60 \mathrm{ppm}$. 


\section{CHAPTER VI}

\section{DISCUSSION}

1. The results of the experiment show that Douglas fir woodchips do have the ability to adsorb sulfur dioxide. However, the adsorptivity, which has been considered to be low on dry wood, is proportional to the moisture content of wood. The higher the moisture content in wood, the greater the adsorptivity of $\mathrm{SO}_{2}$ and also the longer the time required to reach saturation.. This is obviously shown in the figures from Fig. 9 to Fig. 27. For instance, at an influent concentration of $\mathrm{SO}_{2}$ of $1.12 \mathrm{ppm}$. , the dry wood adsorptivity was $4.69 \mathrm{Hg}$. $\mathrm{SO}_{2}$ per $\mathrm{g}$. wood, while it increased to 43.97 on the woodchips wth $20 \%$ molsture and to 348.0 on woodchips which were saturated. The time needed to reach the saturation of $\mathrm{SO}_{2}$ on wood was 45 minutes for the dry wood, up to 240 minutes for the wood with $20 \%$ of moisture and 1,080 minutes for the wood with saturated moisture.

2. In the process of adsorption, gas flowrate through the adsorption bed has an important effect on the adsorption efficiencies. The adsorptivity was greatly reduced by increasing the flowrate of the passing gases to the point where adsorbate had inadequate contact with adsorbent. If the time of retention and adsorption efficiencies are compared with the same moisture content at two different flowrates,. It is found that the retention time of the lower flowrate is longer then that of the higher flowrate and the adsorption efficiencies of the low-rate are also higher than that of highrate. For example, comparisons of an influent $\mathrm{SO}_{2}$ concentration of $1.12 \mathrm{ppm}$ : (1 1iter per minute of flowrate) and $1.83 \mathrm{ppm}$. (2.5 11ter per minute of flow- 
rate) in Tables VI and VII, we find that it took 45 minutes for the flowrate of 1 1iter/min. to reach the end point on dry wood, but at the same conditions, 1t took only 8 minutes for the flowrate of 2.511 ter/min. to do so. The adsorption efficiencies for the flowrate of 1 liter/min. were also higher than those of flowrate of $2.511 t e r / \mathrm{min}$.

3. The quantity of sulfur dioxide adsorbed at different conditions of wood moisture is shown on Figure 28. The adsorption of $\mathrm{SO}_{2}$ op different molsture content of wood can be predicted from these values. For instance, If the influent concentration of $\mathrm{SO}_{2}$ of $1.12 \mathrm{ppm}$. Is employed it can be predicted from Fig. 28 that about 6 grams of woodchips with $100 \%$ of moisture content will retain approximately 1,630 micrograms of $\mathrm{SO}_{2}$.

4. The temperature and humidity in the laboratory, adjusted by the air conditioner, were kept constant. After five measurements at different times, 1t was found that the dry-bulb temperature in the laboratory was $26^{\circ} \mathrm{C}$ $\left(78.8^{\circ} \mathrm{F}\right)$ and the wet-bulb temperature was $19^{\circ} \mathrm{C}\left(66.2^{\circ} \mathrm{F}\right)$. According to humidity chart, the relative humidity $1850 \%$ and the absolute humidity is $0.011 \mathrm{lb}$. water per $\mathrm{lb}$. dry air when the dry-buld temperature is $26^{\circ} \mathrm{C}$ and the wet-bulb temperature is $19^{\circ} \mathrm{C}$. In other words, the air in the laboratory was drier than. the saturated air at the same temperature. The effluent temperature of the adsorber also measured about $26^{\circ} \mathrm{C}$, $1 . e$. , the effluent gas was partially saturated by carrying over some molsture from the wood. Assuming the relative humidity (R. H.) of the effluent gas was ralsed to $80 \%$, the water requirements for the influent gas are then $0.0169-0.011=0.0058$ 1b. $\mathrm{H}_{2} \mathrm{O}$ per $1 \mathrm{~b}$. dry air: If 100 11ters of sampled air are pumped through the adsorber, assuming that the air is at 1 atm. and $26^{\circ} \mathrm{G}$, the quantities - of air can, according to the Idea gas law, be estimated as follows:

$$
W=P V M / R T=(29 \times 1 \times 100) /(0.082 \times 299.2)=118.2 \mathrm{~g} .
$$


and thus the water carried over by air $=118.2 \times 0.0058=0.686 \mathrm{~g}$ per 100 liter of dry air. This means that the moisture in the woodchips was substantially reduced by the carrier gas. Of course, the quantities of molsture lost in the carrier gas are determined by the flowrate of the gas. A low flowrate of gas was applied, it did not cause great difference between the relative humidity of the effluent gas and that of the influent gas. The reason is that the higher flowrate will produce larger forces on the adsorbent from which more moisture will be removed.

5. The total quantities of sulfur dioxide adsorbed on wood were increased with a reduction of, the flowrate of sampled air. As shown in Fig. 28, the total $\mathrm{SO}_{2}$ retained on the wood having 1 liter/min. as the flowrate and $-1.12 \mathrm{ppm}$. $\mathrm{SO}_{2}$ concentration is greater than the other two higher concentrations with higher flowrates. For example, when the quantities of $\mathrm{SO}_{2}$ retained on wood were compared, it was found that there were $2090.5 \mathrm{\mu g}$. of $\mathrm{SO}_{2}$ retained on the wood with saturated moisture content for the influent $\mathrm{SO}_{2}$ concentration of $1.12 \mathrm{ppm}$. with a flowrate of 1 liter/min. However, there were 745.15 Hg. and $1446.2 \mu \mathrm{g}$. of $\mathrm{SO}_{2}$ retained on the wood at the same conditions for the two higher concentrations with higher flowrates. Three reasons are proposed to explain this phenomena: First, the adsorbent cannot be kept in. good condition to retain adsorbate when the larger forces of carrier gas are applied to it. Second, the adsorptivity and absorptivity of wood (with moisture) is greatly affected by the moisture in wood, being gradually carried over by drier carrier gas. Third, the sulfur dioxide originally dissolved in the water and retained in the wood pores' was re-entrained back to the carrier gas as the molsture was gradually transferred from the wood to the carrier gas at the final stage of the experiment. 
6. The difference between the "maximum influent $\mathrm{SO}_{2}$ concentration used In this experiment, $4.60 \mathrm{ppm}$. $\left(11.6 \mathrm{mg} / \mathrm{M}^{3}\right)$, and that of most Industrial plants is very large. There is no doubt, however, that the higher the concentration of $\mathrm{SO}_{2}$ in the flue gas, the more sulfur dioxide would be removed by wood and molsture.

7. It was found by taking samples without the adsorbent in the system that no sulfur dioxide was adsorbed by the adsorber or by any adsorption equipment. In other words, there was no $\mathrm{SO}_{2}$ lost in the adsorption system caused by the tubings and the materials of the adsorber.

8. By substituting the observed results in the Freundlich equation, it was found that most of the data fit the equation. The straight ines in F1g. 29 to 31 show that the Freundlich equation can be used to describe the adsorption of sulfur dioxide on wood. As presented in Table IX and Section 6 of Chapter V, the values of the constant " $K$ " In the Freundlich equation, Eq. [3], Increase with increasing molsture content in wood. On the contrary", the slope " $n$ " decreased with an increase in the molsture content in wood. Also, it was found that the values of " $K$ " of the dry wood samples $1.1,0.13$ and 0.10 , were all much lower than those of wood containing moisture. The adsorptivity of sulfur dioxide between dry " and wet wood was greatly different. This situation was, however, reduced when more water was added to the wood as shown in Fig. 29, etc. Therefore, we can predict that the adsorptivity of sulfur dioxide on wood has a limit no matter how much molsture it contains, because it changes into the absorption of sulfur dioxide in water and the absorptivity is increased when the wood retains the extra molsture. By means of the Freundich equaţion, it is . possible to closely calculate the adsorption phenomena of the sulfur dioxide 
6

on wood at various moisture contents:

9. The accuracy of Eq. [7] has been confirmed by substituting and checking most of the data from Appendix Table 1 to 15. The constant $k$ in Eq. [8] can, therefore, easily be obtained if the values of $C_{a}$ and $C_{b}$ are measured and evaluated. For example, $C_{b}=1.12 \mathrm{ppm} ., V=111$ ter $/ \mathrm{min} ., \mathrm{M}_{\mathrm{s}}=6.25 \mathrm{~g}$. , when $t=18$ minutes, $c_{a}=0.91$ ppm., substituting into Eq. [8], we have

$$
\begin{gathered}
0.91=1.12(1-\exp (-\mathrm{k} \times 1 \times 18 / 6.25)) \\
k=0.592
\end{gathered}
$$

Therefore, when $t=5 \mathrm{~min}$, the theoretical value of $\mathrm{C}_{\mathrm{a}}$ should be

$$
c_{a}=1.12(1-\exp (-0.592 \times 1 \times 5 / 6.25))=0.43 \mathrm{ppm} . " “
$$

This is compared to the experimental result of $0.59 \mathrm{ppm}$. By the same method of calculation, when $t=40^{\circ} \mathrm{min}, \mathrm{C}_{\mathrm{a}}$ is obtained to be $1.09 \mathrm{ppm} .$, which is compared to the experimental value of $1.07 \mathrm{ppm}$.

Another example, $c_{b}^{\prime}=1.83$ ppm., $V=2.511$ ter $/ \mathrm{min} ., M_{8}=6.15 \mathrm{~g}$. , when $t=3$ min., $c_{a}=1.72 \mathrm{ppm}$, constant $k$ is determined to be 2.3 . By the same format of calculation mentioned above, when $t=7$ min., we have $c_{a}=1.828 \mathrm{ppm}$. compared to the experimental result of $1.825 \mathrm{ppm}$. Also, when $t=1$, the $C_{a}$ is calculated to be $1.12 \mathrm{ppm}$. compared to the experimental result of $1.30 \mathrm{ppm}$.

The third example, $c_{b}=4.60$ ppm., $k$ is determined to be 3.0 when $\nabla=2.5$ liter/min., $M_{8}=6.40 \mathrm{~g} .$, and $t=3 \mathrm{~min}, \mathrm{C}_{\mathrm{a}}=4.47 \mathrm{ppm}$. We then obtain $C_{a}=4.59 \mathrm{ppm}$ (when $t=7$ ) compared to the experimental value of $4.56 \mathrm{ppm}$ and $\mathrm{C}_{a}=3.18 \mathrm{ppm}$. (when $t=1$ ) compared to the experimental value of $3.96 \mathrm{ppm}$.

Wreover, the adsorptivity and the retention time of wood on the . adsorption of sulfur dioxide to any concentration of sulfur dioxide may, according to the same equation developed, be estimated. 
CHAPTER VII

SUMRARY AND CONCLUSION

\section{Summary}

1.1 The study of the adsorption of sulfur dioxide on Douglas fir woodchips has shown that the wood can be used as an adsorbent to selectively remove sulfur dioxide from a dilute gaseous air-SO ${ }_{2}$ stream. The molsture content in wood played an important part in the adsorption of $\mathrm{SO}_{2}$. The adsorption efficiencies were very satisfactory for moistened wood especially for saturated wood. The Freundlich equation can be used to describe the adsorption of sulfur dioxide on woodchips. Other equations were developed to predict the amount of sulfur dioxide accumulated In wood, to predict the time needed to reach saturation of sulfur dioxide on wood, and to predict the effluent concentrations from the adsorbent bed.

1.2 At an influent concentration of $\mathrm{SO}_{2}$ of $1.12 \mathrm{ppm}$. ( $2.94 \mu \mathrm{\mu g} \mathrm{SO}_{2}$ per 1iter) and with a flowrate of 1 liter/minute, dry Douglas fir woodchips were found to have an adsorptivity of $4.69 \mu \mathrm{g}$. of $\mathrm{SO}_{2}$ per gram of wood; 11 percent moisture of woodchips increased the adsorptivity to 29.13 ; 20 percent to 43.97 ; 50 percent to 205.8 ; and saturated woodchips to 348.0 . The time of the experiment taken to reach saturation of sulfur dioxide on wood was 45 minutes for dry wood. It was increased to 210 minutes for 11 percent molsture; to 240 minutes for 20 percent; to 720 minutes for 50 percent; and to 1,080 minutes for the saturated wood.

1.3 At an influent concentration of $\mathrm{SO}_{2}$ of $1.83 \mathrm{ppm}$. $\left(4.79 \mu \mathrm{\mu g} \mathrm{SO}_{2} \mathrm{per}\right.$ 11ter) and with a flowrate of 2.511 ter/minute, dry wood was found to 
give an adsorptivity of $1.26 \mu \mathrm{g} \cdot \mathrm{SO}_{2}$ per gram of wood, which increased to 9.56 for 11 percent molsture; 18.35 for 20 percent; 21.35 for 50 percent; and 106.38 for saturated wood. The tIme needed to reach saturation was 8 minutes for the dry wood. Eleven percent moisture increased it to 16 minutes; 20 percent to 18 minutes; 50 percent to 35 minutes; and saturated was 300 minutes. 1.4 At an influent concentration of $\mathrm{SO}_{2}$ of $4.60 \mathrm{ppm}$. (12.05 $\mu \mathrm{g} . \mathrm{SO}_{2}$ per 1iter) and with a flowrate of 2.5 liter/min, dry wood was found to have an adsorptivity of $2.38 \mathrm{\mu g}$. $\mathrm{SO}_{2}$ per gram of wood; 11 percent moisture Increased the adsorptivity to 32.2 ; 20 percent to 76.7 ; 50 percent to 168.56; and saturated to 209.56. The time required to reach saturation

4 was 9 minutes for the dry wood, and then increased to 30 minutes for the wood with 11 percent of molsture; to 80 minutes for 20 percent; 93 minutes for 50 percent; and 125 minutes for saturated wood.

\section{Conclusion}

Wood can adsorb sulfur dioxide at least at high concentrations. This has already been shown in some sources which mentioned that the sulfur dioxide in a solution of 2 to 10 percent of $\mathrm{SO}_{2}$ can be adsorbed either by sprucewood or hemlock chips. For lower ranges of sulfur dioxide concentrations, this study has shown that Douglas fir woodchips can be used as the adsorbent to remove traces of sulfur dioxide from a gas stream regardless of its low adsorptivity on dry wood.

The adsorptivity of the sulfur dioxide on wood is closely related to the moisture content of wood and is reduced with an Increase in the flowrate of the carrier gases. More research is needed to determine an optimum gas flowrate through an adsorber to obtain a maximum adsorption equilibrium. 
Extensive emission of sulfur dioxide is a problem in many industries. It was found in this study that traces of sulfur dioxide in the air can be adsorbed on wood especially on those with sufficient moisture. The efficiencies of sulfur dioxide removal by moistened wood reached 100 percent during the first minute in some experiments. The Pacific Northwest Is one of the main lumber producing areas in the United States and a great amount of waste woodchips and sawdust are produced from the lumber Industry. Using woodchips to treat the residual sulfur dioxide in the waste gases of the plants may not only solve the problem of afr pollution but the problem of some solid waste disposal.

Sulfur dloxide retained in wood may present further research topics of how to treat the woodchips which contain $\mathrm{SO}_{2}$, how to utilize and/or recover the chips and how to apply to the industrial production. In spite of the problems of treatment of the woodchips, this report may at least bring about an idea to some of the industries such as sulfite pulp industry for providing a means of control of sulfur dioxide pollution and the recovery of raw material. It also reveals that some other pollutants, for instance, hydrogen sulfide, carbon monoxide, ammonia, nitrogen oxides, etc. may be considered as the adsorbate and using wood for further adsorption studies. 
-1 1. At sukawa, M., Nishimoto, Y., \& Matsumotó, K., "Mitsubishi process for the removal of $\mathrm{SO}_{2}$ from waste gases", C. mical Laboratory of Hiroshima Technical Insitute (1964).

2. Bienstock, D., Brunn, L. W., Murphy, E. M., Benson, H. E., "Sulfur dioxide--its chemistry and removal from industrial waste gases", Burea of Mines Information Circular 7836, U. S. Depart nt of Interior (1958).

3. Brauns, F. E., "The chemistry of lignin", Academic Press, Inc., New York (1952).

4. Brown, N. C.., "Forest products, their manufacture and uses", John Wiley \& Sons, Inc., New York (1919).

5. Brown, H. P., Panshin, A. J., \& Forsaith, C. C., "Textbook of wood technology", Vol. II, McGraw-Hill Book Co., Inc., New York (1952).

6. Brunauer, S., "The adsorption of gases and vapors". Princeton University Press (1945).

7. Campbell, J. N., Ashford, F. E., Needham, R. B., \& Reid, L. S., "More insight into adsorption design", Hydrocarbon Processing and Petroleum Refinery, Vol. 42, No. 12, pp. 89-96, Dec. (1963).

8. Carter, J. W., "Adsorption process, Part 1 and Part 2", Chemical and Process Engineering, Aug. and Sept. (1966).

9. Chemical Englneering Progress, Symp. Service, 55(24), 1(1959).

10. Department of Environmental Quality, Air Quality Control Division, State of Oregon, "Report on Oregon's air quality and program" for years 1968 and $1969^{\prime \prime}$, Pp. 10-11.

11. "Douglas fir use book", Western Wood Product Association, Portland, - Oregon (1964).

12. Eguchi, Y., "Removà of sulfur dioxide gas from waste gases by activated carbon", from Japanese Sulfuric Acid Association: "Sulfuric Acid", Vol. 18, No. 9, pp. 9-14 (1965).

13. Electrical World, Vol. 168, No. 20, p. 101, Nov. 13 (1967).

14. Coldsmith, J. H., "Effect of air pollution on humans", from A. C. Stern, ed1t.: "Air. Pollution", Vol. I, pp. 335-386 (1968) Academic Pres8, New York. 
15. Journal of Alr Pollution Control Association, Vol. 11, No. 5, p. 219, May (1961).

16. Katz, M., "Analysis of Inorganic gaseous pollutants", from A. C. Stern, edit.: "Alr Pollution", Academic Press. New York. Vol. II, pp. 55-60 (1968).,

17. Katz, M., "Measurement of air pollutants", World Health Organization, Geneva (1969).

18. Katz, M., "Sulfur dioxide in the atmosphere and its relation to plant 1ife" "Industrial \& Engineering Chemistry, Vol. 41, No. 11 , Nov. (1949).

19. Krejcar, E., "An Ion exchange resins as sorbent for $\mathrm{SO}_{2}$ ", (Chem. Prum., Vol. 15, Pp. 77-79, 1965), Journal of Applied Chemistry, Aug. (1965).

20. Langmuir, I., Journal of American Chemical Society, 38, 2267 (.1916) and 40,1361 (1918).

21. Martin, D. A., \& Brantley, F. E., "Selective adsorption and recovery of $\mathrm{SO}_{2}$ from industrial gases by using synthetic zeolite", U. S. Bureau of Mines, Rep. Invest., 1963, No. 6321), Journal of Applied Chemistry, p. 1-377, Apr. (1964)

22. Metronics Product Bulletin, No. 20-68, Metronics Association, Inc., Stanford Industrial Park, Palo Alto, California.

23. Nelson, N., "Biological aspects of air pollution", from Mallete, F. S., "Problems and control of air pollution", and At C. Stern, edit.: "Air Pollution", Academic Press. New York. Vol. I, (1968).

24. Perry, J. H., "Chemical Engineering Handbook", McGraw-Hill Book Co., Inc., New York, 3rd (1950). and 4th (1963) edition.

25. Rachinskii, V. V., "Introduction to the general theory of dynamics of sorption and chromatography", IZD. "Nauka", Hoscow, Russia (1964).

26. Rees, R. L., "Removal of sulfur dioxide gas from power plant stack gases", British Electricity Authority, London, England, (1964).

27. Rohrman, F. A., \& Ludwig, J. H., "Sources of sulfur dioxide pollution", Chemical Engineering Progress, Vo1. 61, No. 9, pp. 59-63, Sept. (1965).

28. Rossano, A. T., "Alr pollution control guidebook for management", Environmental Science Service Division, p. 89 (1969).

29. Sherviood, T. K., "Solubility of sulfur dloxide and ammonia In water", Industrial \& Engineering Chemistry, Vol. 17, No. 7, pp. 745-6, July (1925). 
30. Tebbens, B. D., Thomas, J. F., Sanborn, E. N. \& Muka1, M., "Hydrocarbon synthesis in combustion. II. Liquid fuels" Am. Ind. Hyg.. Assoc. Quart., 18, 165-71, June (1957).

31. Terraglio, F. P., Manganell1, R. M., "he Influence of molsture on the adsorption of atmospheric "ifur dioxide by soll", Journal of Air \& Water Pollut. I: ., , Vol. 10, pp. 783-791 (1966).

32. Treybal, R. E., "Mass transfer operation", McGraw-H111 Book Co., Inc., New York, Pp. 201-56 (1955).

33. U. S. Department of Agriculture, Forest Service, "Timber resources for America's future", Forest Resources Report No. 14 (1958).

34. . S. Department of Health, Education and Welfare, Public Health Service, "Air quality criteria for sulfur dioxide", National Air Pollution Control Administration, Washington, D. C. Jan. (1969).

35. Van Brackle, R.'D., "The farmers stake in air pollution", Solls and Crops, Oct. (1967).

36. Vianikoy, L. I., Mukhlenov, I. P., \& Lesoklin, I. G., "Adsorption of sulfur dioxide in a bed with ideal mixing", Journal of the Applied Chemistry of the U. S. S. R., Vol. 40, No. 9,

37. Yocum, J. E., "Effect of air pollution on materials", from A. C. Stern, edit.: "Air Pollution", Academic Press. New York. Vo1. I, pp. 199-219 (1968). 


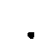

,

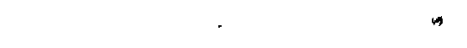

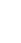

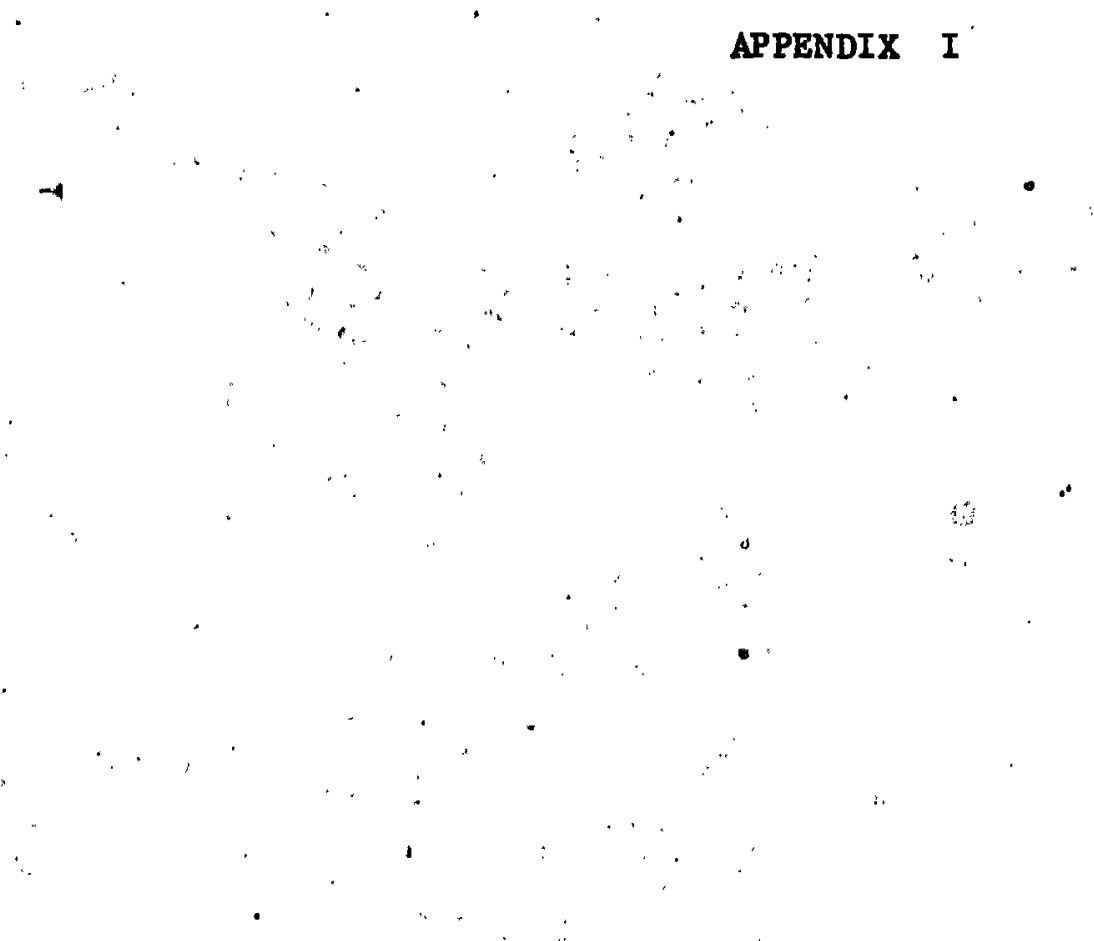


APPENDIX I

SOLUBILITY OF SULFU DIOXIDE IN WATER

We1ght of $\mathrm{SO}$ per 100 wt. of water

Partial pressure of $\mathrm{SO}_{2}$, mm. $\mathrm{Hg}$.

\begin{tabular}{lrrrrrrrrr}
20 & 646 & 657 & & & & & & \\
15 & 474 & 637 & 726 & & & & & \\
10 & 308 & 417 & 474 & 567 & 698 & & & \\
7.5 & 228 & 307 & 349 & 419 & 517 & 688 & & \\
5.0 & 148 & 198 & 226 & 270 & 336 & 452 & 665 & \\
2.5 & 69 & 92 & 105 & 127 & 161 & 216 & 322 & 458 \\
1.5 & \multicolumn{1}{c}{38} & 51 & 59 & 71 & 92 & 125 & 186 & 266 \\
1.0 & 23.3 & 31 & 37 & 44 & 59 & 79 & 121 & 172 \\
0.7 & 15.2 & 20.6 & 23.6 & 28.0 & 39.0 & 52 & 87 & 116 \\
.5 & 9.9 & 13.5 & 15.6 & 19.3 & 26.0 & 36 & 57 & 82 \\
.3 & 5.1 & 6.9 & 7.9 & 10.0 & 14.1 & 19.7 & & \\
.2 & 2.8 & 3.7 & 4.6 & 5.7 & 8.5 & 11.8 & $\ldots .0$ & 31.0 \\
.15 & 1.9 & 2.6 & 3.1 & 3.8 & 5.8 & 8.1 & 12.9 & 20.0 \\
.10 & 1.0 & 1.2 & 1.5 & 1.75 & 2.2 & 3.2 & 4.7 & 7.5 & 12.0 \\
.05 & .0 .6 & 0.7 & 0.75 & 0.8 & 1.2 & 1.7 & 2.8 & 4.7 \\
.02 & & .25 & .3 & .3 & .3 & 0.5 & 0.6 & 0.8 & 1.3
\end{tabular}
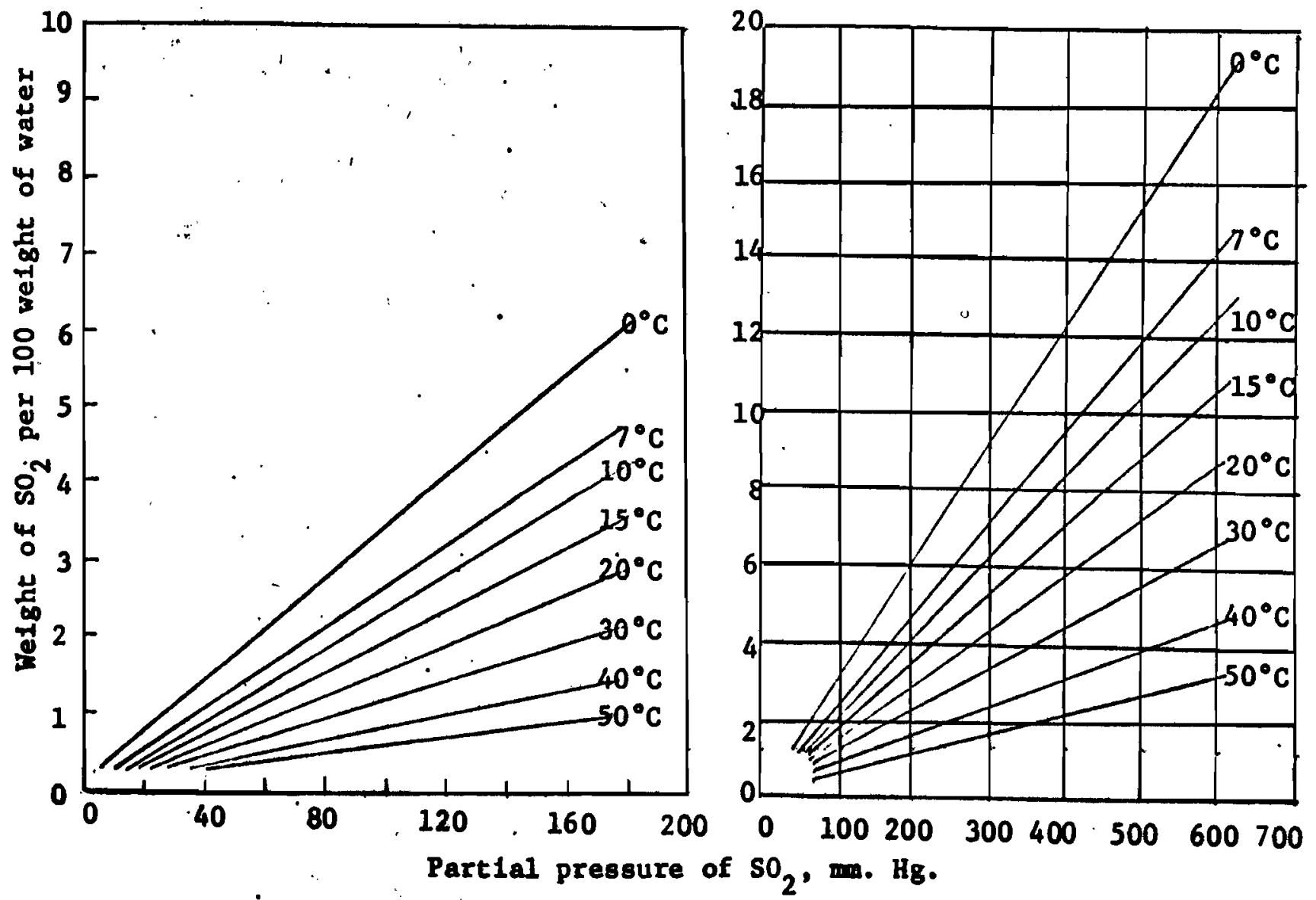


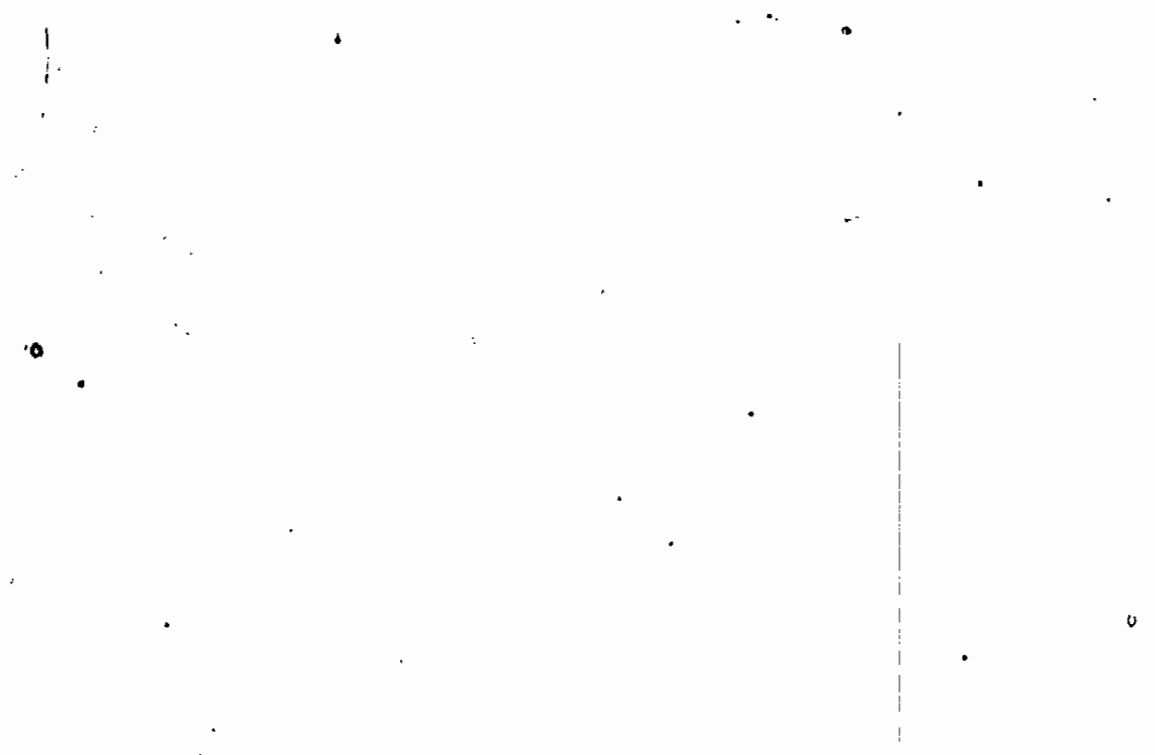

APPENDIX II 
APPENDIX II

\section{ESTIMATION OF ADSORBER DIAMETER}

Campbeli, et. al. (7) developed an equation for the diameter of requịed adsorbent. bed as shown in equation (9) of the text:

$$
D=\left[25\left(W_{g}\right)\left(T_{f}\right) /\left(P_{f}\right)\left(V_{g}\right)\right]^{\frac{1}{2}}
$$

where $\quad D=$ required adsorbent bed diameter, $f t$.

$W_{g}=$ gas flowrate, million cu. ft. per day (MCFD)

$T_{f}=$ Temperature in adsorber, ${ }^{O_{R}}$

$P_{f}=$ Pressure in adsorber, psia

$V_{g}$ - linear gas velocity, ft./min.

Assume that the gas flowrate through the adsorbent bed is 1 1iter/min.,

then

$$
\begin{aligned}
w_{8} & =11 \text { lter/min. }-0.0353 \mathrm{cu} . \mathrm{ft} . / \mathrm{min} .=50.8 \mathrm{ft}^{3} / \mathrm{day} \\
& =50.8 \times 10^{-6} \mathrm{MMCFD}
\end{aligned}
$$

Diameter of adsorber used is, $D=1.7 \mathrm{~cm} .=0.0558 \mathrm{ft}$.

Cross-sectional area of adsorber, $A=(0.0558)^{2} \pi / 4=2.47 \times 10^{-3} \mathrm{ft}^{2}$

Gas Iinear velocity, $v_{g}=0.0353 / 2.47 \times 10^{-3}=14.3 \mathrm{ft} . / \mathrm{min}$.

$$
\mathrm{T}_{\mathrm{f}}=26^{\circ} \mathrm{C}=78.8^{\circ} \mathrm{F}=538.8^{\circ} \mathrm{R}_{;} \quad \mathrm{P}_{\mathrm{f}}=14.7 \mathrm{psia}
$$

Thus the diameter of required adsorbend is

$$
\begin{aligned}
D & \left.=\left[25\left(50.8 \times 10^{-6}\right)(538.8) / 14.7\right)(14.3)\right]^{\frac{2}{2}}-5.68 \times 10^{-2} \mathrm{ft} . \\
& =1.73 \mathrm{~cm} .
\end{aligned}
$$

- The diameter of adsorber used, according to the calculation, is just marginal for having 1 liter/min. of gas flow through the adsorbent bed. If the maximum linear velocity of the gas remained unchanged at 14.3 ft./min., and the flowrate increases to 2.511 ter/min. while other con- . ditlons remaining at constant, the required adsorber diameter will then be

$$
D=(2.5 / 1)^{\frac{1}{2}} \times 1.73=2.73 \mathrm{~cm} \text {. }
$$




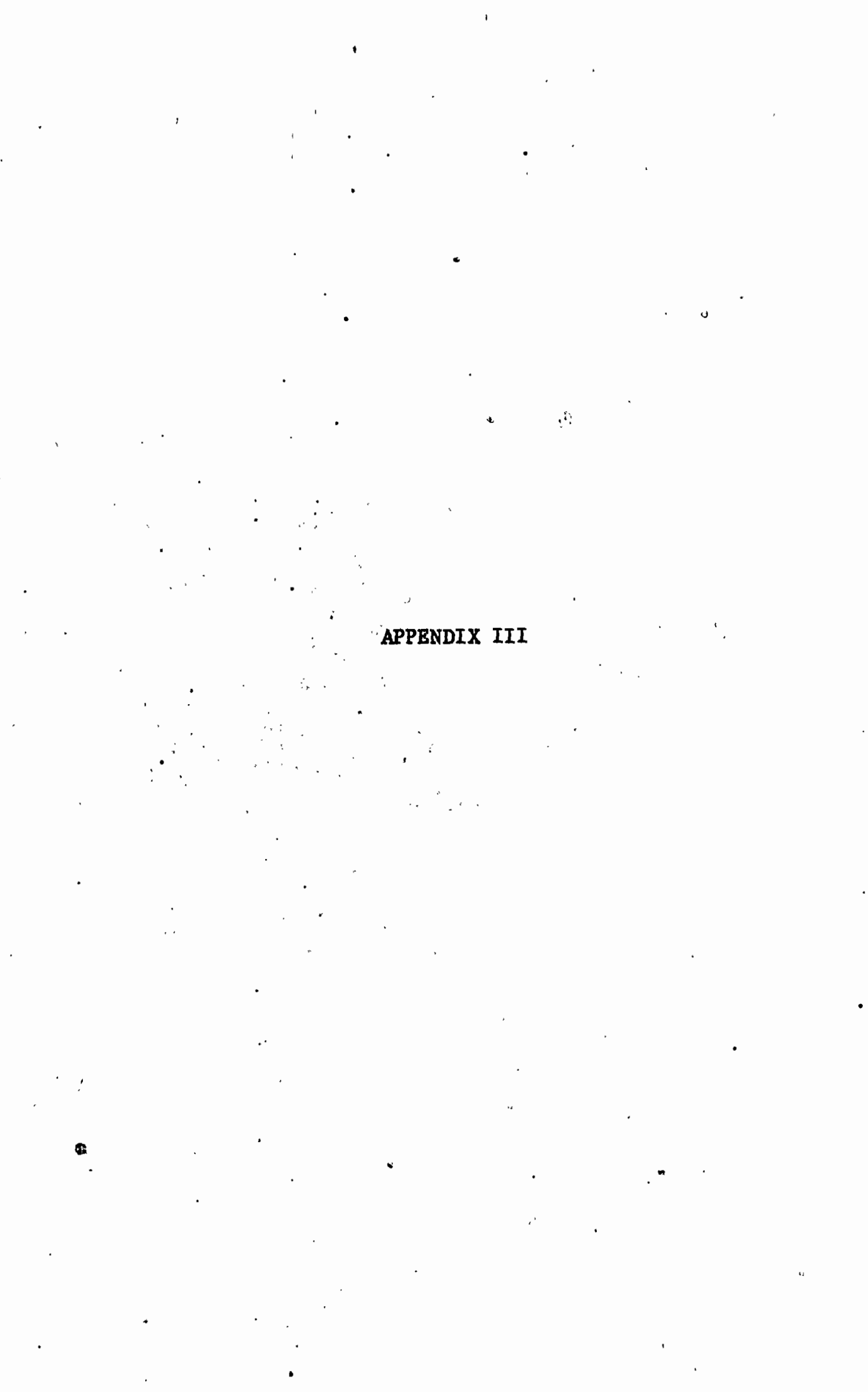


APPENDIX III

DETERMINATION OF SULFUR DIOXIDE BY WEST AND GAEKE METHOD

1. Principle:

Sulfur dioxide reacts with tetrachloromercurate to form the dichlorosulfitomercurate ion, which reacts with acid-bleached para-rosaniline and formaldehyde to produce a red purple color. A spectrophotometer, which sets the exact wavelength, is used to distinquish the samples from the different concentration of sulfur dioxide.

2. Preparation of required reagents:

2.1 Absorbing reagent: 0.1 M. sodium tetrachloromercurate

Dissolve $27.2 \mathrm{~g} \cdot(0.1 \mathrm{~mole})$ of mercuric chloride and $11.7 \mathrm{~g} \cdot(0.2$ mole of sodium chloride in 1 liter of distilled water.

2.2 Para-rosaniline hydrochloride $(0.04 \%)$, acid bleached

2.2.1 Dissolve $0.2 \mathrm{~g}$. of para-rosaniline hydrochloride in $100 \mathrm{ml}$. of distilled water and filter it after 48 hours.

2.2.2 Pipette $20 \mathrm{ml}$. of the filtered solution into $100-\mathrm{ml}$ volumetric flask and add $6 \mathrm{ml}$. of concentrated $\mathrm{HCl}$ acld.

2.2.3 Allow the mixture to stand for 5 minutes, then dilute to mark

- with distilled water. This solution is a pale yellow in color with a greenish tint. It can be stored for about 2 weeks if refrigerated.

2.3 Formaldehyde, $0.2 \%$

Dilute $5 \mathrm{ml}$. of $40 \%$ of formaldehyde to 1 liter with distilled water. 2.4 Standard sulfite solution, $3.0 \mathrm{ul} \cdot \mathrm{SO}_{2}$ per ml. of solution

Dissolve 59.7 mg. of sodium metabisulfite (assay $67 \%$ as $\mathrm{SO}_{2}$ ) in 100 ml. of distilled water. This ylelds a solution of $0.40 \mathrm{mg} \mathrm{SO}{ }_{2}$ per ml. 
3.7.3 Add $1.0 \mathrm{ml}$. of acid-bleached para-rosaniline solution and $1.0 \mathrm{ml}$. of the $0.2 \%$ formaldehyde solution to each tube and $\mathrm{mix}$.

3.7.4 Allow 20 minutes for maximum color development and use the blank as the reference to read the absorbance of each samples at $560 \mathrm{mu}$.

3.7.5 Plot the absorbance (optical density) as the abscissa against the ul. of $\mathrm{SO}_{2}$ per $10 \mathrm{ml}$. of absorbing solution on rectangular coordinate paper (Appendix Figure 1). Compute the slope of the straight line. 4. Calculation of the $\mathrm{SO}_{2}$ concentration:

4.1 Convert the volume of air sampled to the volume at standard conditions of $25^{\circ} \mathrm{C}$ and $760 \mathrm{Hg}$. The equation 18

$$
v_{8}=V \times\left(P-P_{m}\right) \times(298.2) /(760) \times(t-273.2)
$$

where $\quad V_{8}=$ volume of air in liters at standard conditions

$$
V \text { - volume of air in liters as measured by the meter }
$$$$
\text { P - barometic pressure in millimeter of mercury }
$$

- $P_{m}=$ suction at meter in millimeter of mercury

$$
\text { t - temperature of sample air in }{ }^{\circ} \mathrm{K}
$$

Generally, the correction for pressure is very small and may be overlooked. 4.2 Compute the microliters (ul.) of $\mathrm{SO}_{2}$ in the sqmple by multiplying. the absorbance by the slope of the calibration curve.

4.3 The concentration of sample can be calculated by

$\because \quad$ Ppm. of $\mathrm{SO}_{2}$ by volume $=\mathrm{ul} \cdot \mathrm{SO}_{2} / \mathrm{v}_{8}$

. 


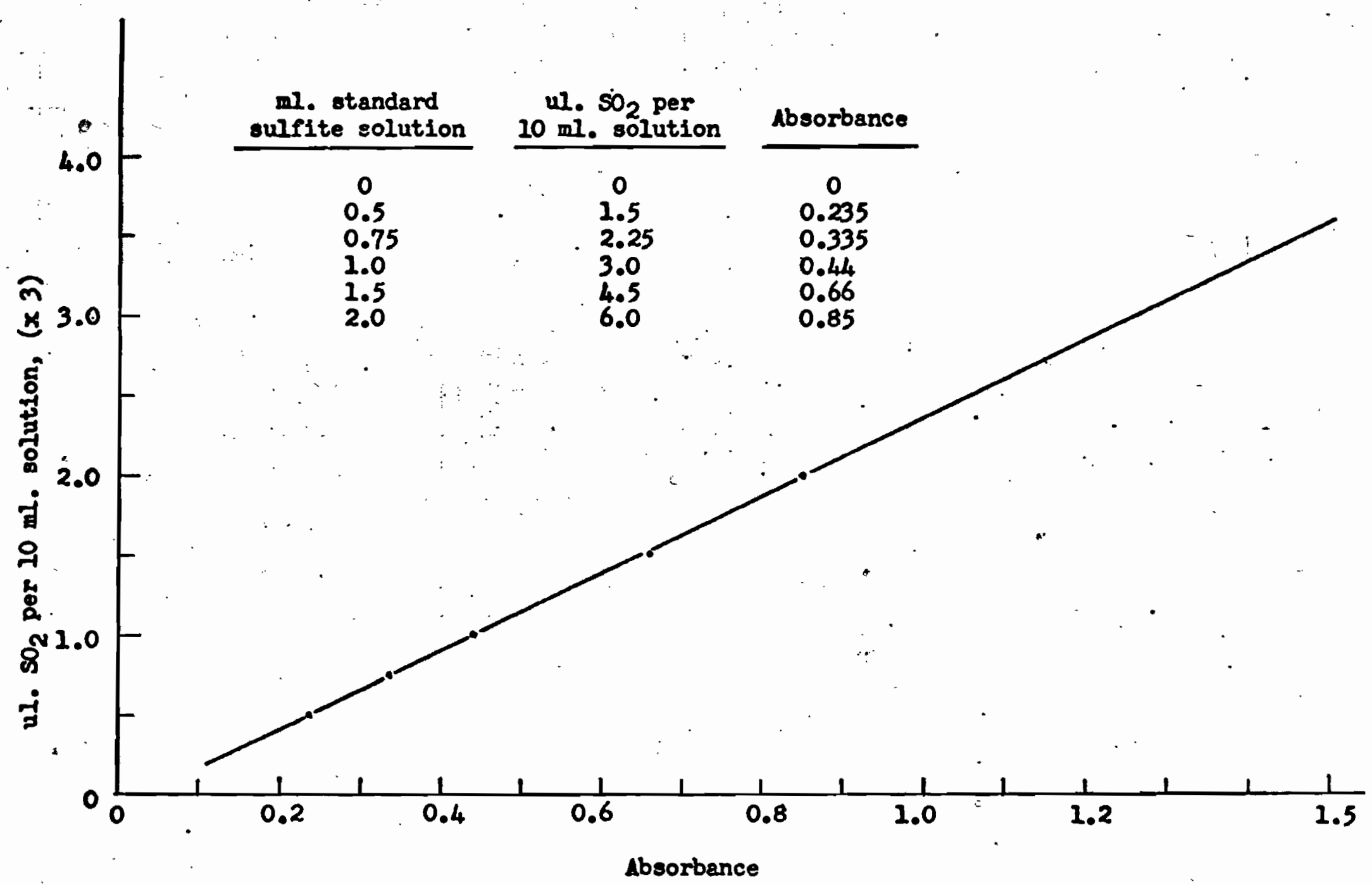

Appendix F18. I:- Calibration curve in the analysis of $\mathrm{SO}_{2}$ by West and Gaeke Method 
$n$
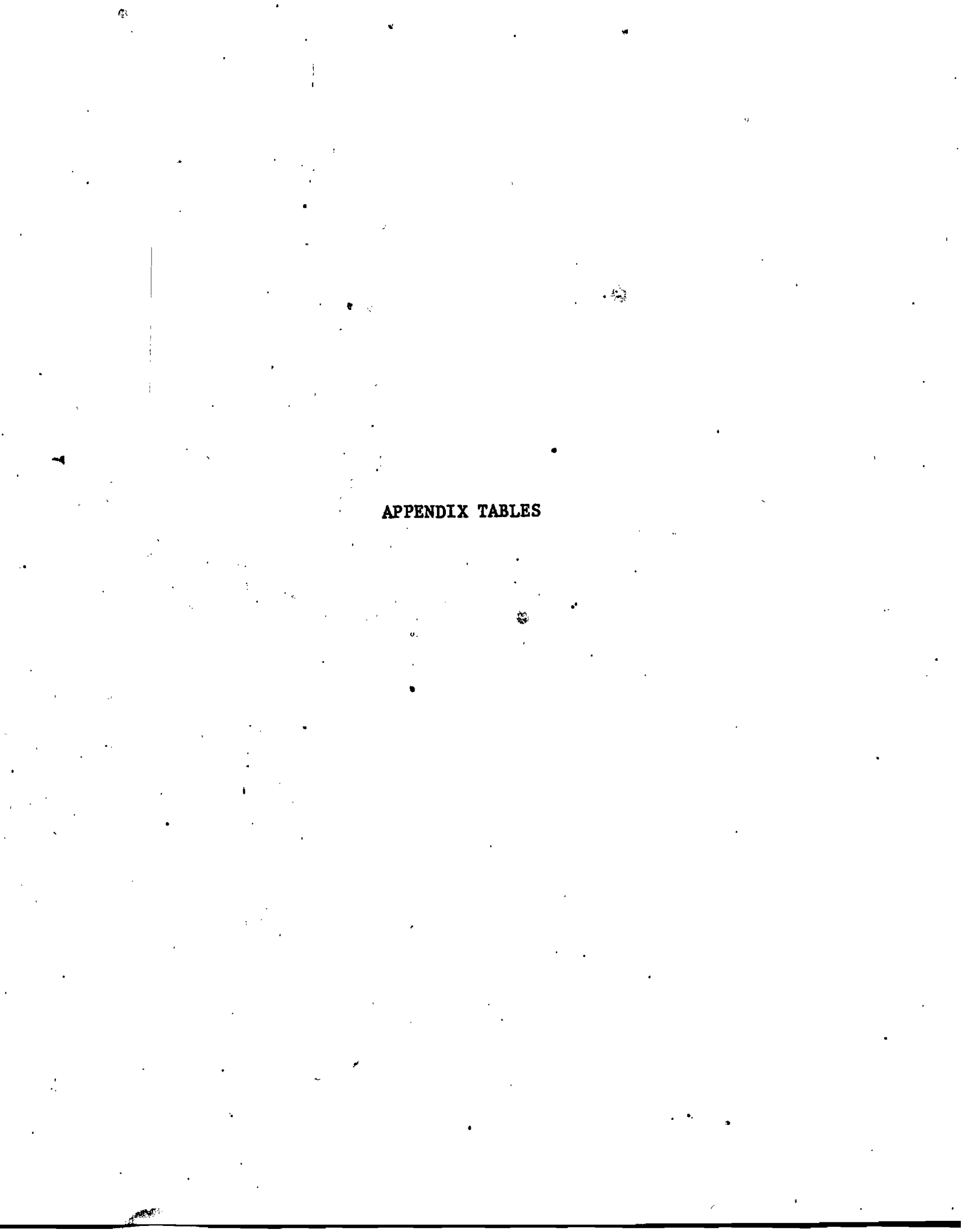

. 
Appendix Table 1. Calculation of cunilative amount of $\mathrm{SO}_{2}$ on dry wood for an influent $\mathrm{SO}_{2}$ concentration 'o' of $1.12 \mathrm{ppm}$.

Dry wood ised $=6.25 \mathrm{~g}$.

Gas flowrate through the adsorber - 111 ter/min.

\begin{tabular}{|c|c|c|c|c|c|c|c|c|c|}
\hline$\underset{t}{\text { Time }}$ & $\begin{array}{c}\text { Sampling } \\
\text { time } \\
\text { min. }\end{array}$ & $\begin{array}{c}\text { Vol. } \\
1 .\end{array}$ & $\begin{array}{l}\text { Effl. } \\
\text { so } \\
\text { cont. } \\
\text { ppm. }\end{array}$ & $\begin{array}{l}\mathrm{SO}_{2} \\
\text { on } \\
\text { ppm. }\end{array}$ & $\begin{array}{l}\text { dsorbed } \\
\text { wood } \\
\mu g / 1 \text {. }\end{array}$ & $p^{*} /$ & $\begin{array}{l}\text { Quants } \\
\text { on } \\
\text { C } t \text {, } \\
\mu g \text {. }\end{array}$ & $\begin{array}{l}1 \text { ty of } \mathrm{SO}_{2} \\
\text { wood } \\
\text { Cun. } \mathrm{Ct} \text {, } \\
\mu \mathrm{g} \text {. }\end{array}$ & $\begin{array}{l}\text { Wood } \\
\text { Adsorptivity } \\
\mu g . \mathrm{SO}_{2} / \mathrm{g} \text {.wood }\end{array}$ \\
\hline $\begin{array}{r}0 \\
3 \\
5 \\
9 \\
12 \\
.15 \\
18 \\
21 \\
24 \\
27 \\
30 \\
35 \\
40 \\
45\end{array}$ & $\begin{array}{l}1 \\
3 \\
3 \\
3 \\
3 \\
3 \\
3 \\
3 \\
3 \\
3 \\
3 \\
5 \\
5 \\
4\end{array}$ & $\begin{array}{l}1 \\
3 \\
3 \\
3 \\
3 \\
3 \\
3 \\
3 \\
3 \\
3 . \\
3 \\
5 \\
5 \\
4\end{array}$ & $\begin{array}{l}0.38 \\
0.47 \\
0.59 \\
0.61 \\
0.68 \\
0.32 \\
0.91 \\
0.95 \\
0.97 \\
1.00 \\
1.02 \\
1.04 \\
1.07 \\
1.08\end{array}$ & $\begin{array}{l}0.74 \\
0.65 \\
0.53 \\
0.51 \\
0.44 \\
0.30 \\
0.21 \\
0.17 \\
0.15 \\
0.12 \\
0.10 \\
0.08 \\
0.05 \\
0.04\end{array}$ & $\begin{array}{l}1.94 \\
1.70 \\
1.49 \\
1.34 \\
1.15 \\
0.79 \\
0.55 \\
0.45 \\
0.39 \\
0.31 \\
0.26 \\
0.21 \\
0.13 \\
0.11\end{array}$ & $\begin{array}{l}0.340 \\
0.410 \\
0.527 \\
0.545 \\
0.607 \\
0.731 \\
0.812 \\
0.848 \\
0.866 \\
0.895 \\
0.911 \\
0.930 \\
0.956 \\
0.965\end{array}$ & $\begin{array}{l}1.94 \\
5.10 \\
4.47 \\
4.02 \\
3.45 \\
2.37 \\
1.65 \\
1.35 \\
1.17 \\
0.93 \\
0.78 \\
1.05 \\
0.65 \\
0.44\end{array}$ & $\begin{array}{r}1.94 \\
7.04 \\
11.57 \\
15.53 \\
18.98 \\
21.35 \\
23.00 \\
24.35 \\
25.52 \\
26.45 \\
27.23 \\
28.28 \\
28.93 \\
29.37\end{array}$ & $\begin{array}{l}0.31 \\
1.13 \\
1.84 \\
2.48 \\
3.19 \\
3.42 \\
3.68 \\
3.89 \\
4.08 \\
4.24 \\
4.35 \\
4.53 \\
4.63 \\
4.69\end{array}$ \\
\hline
\end{tabular}


Appendtx Table 2. Calculation of cumulative amount of $\mathrm{SO}_{2}$ on wood
with $11 \% \mathrm{H}_{2} \mathrm{O}$ for an influent $\mathrm{SO}_{2}$ concentration
of $1.72 \mathrm{ppm}$.

Dry wood used $=7.0 \mathrm{~g}$.

Water added $=0.77 \mathrm{mI}$.

Gas flowrate through the adsorber I I liter/min.

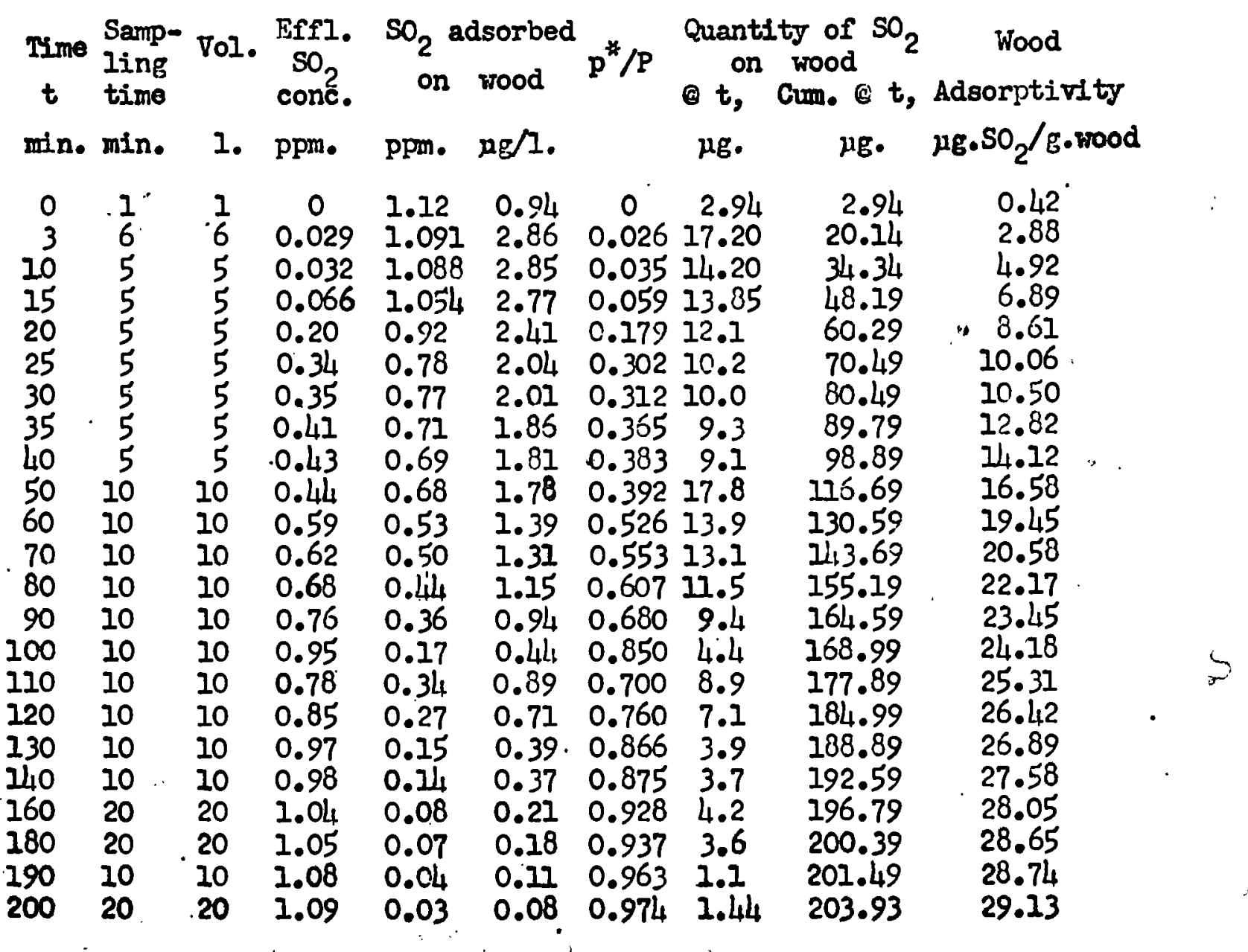


Appendix Table 3. Calculation of cumlative amount of $\mathrm{SO}_{2}$ on wood with $27 \% \mathrm{H}_{2} \mathrm{O}$ ior an influent $\mathrm{SO}_{2}$ concentration of 1.12 ppm.

Dry rood used $=6.81 \mathrm{~g}$.

Water added $=1.37 \mathrm{ml}$.

Gas Nowrate through the adsorber $=1$ liter/min.

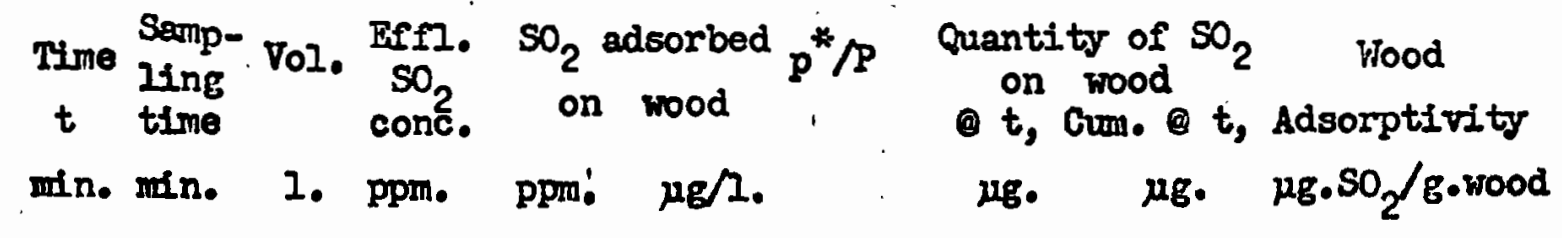

$\begin{array}{rrrrrrrrrrr}0 & & & 0 & & & & & & \\ 10 & & & & 0 & \ldots & & & & & \\ 20 & & & 0 & & & & & & & \\ 35 & & & 0 & & & & & & \\ 15 & 50 & 50 & 0 & 1.12 & 2.94 & 0 & 147.0 & 147.0 & 21.57 \\ 60 & 15 & 15 & 0.17 & 1.01 & 2.64 & 0.098 & 39.6 & 186.4 & 27.28 \\ 75 & 15 & 15 & 0.53 & 0.59 & 1.55 & 0.147 & 23.2 & 209.8 & 30.64 \\ 90 & 15 & 15 & 0.78 & 0.34 & 0.89 & 0.70 & 13.3 & 223.1 & 32.73 \\ 100 & 10 & 10 & 0.65 & 0.47 & 1.23 & 0.58 & 12.3 & 235.4 & 34.45 \\ 115 & 15 & 15 & 0.87 & 0.25 & 0.66 & 0.78 & 9.9 & 245.3 & 35.97 \\ 125 & 20 & 20 & 0.73 & 0.39 & 1.02 & 0.65 & 20.4 & 265.7 & 38.92 \\ 150 & 15 & 15 & 0.88 & 0.24 & 0.63 & 0.78 & 9.5 & 275.2 & 40.38 \\ 160 & 15 & 15 & 0.95 & 0.17 & 0.44 & 0.85 & 6.6 & 281.8 & 41.25 \\ 180 & 20 & 20 & 0.97 & 0.15 & 0.39 & 0.86 & 7.8 & 289.6 & 42.38 \\ 200 & 20 & 20 & 1.014 & 0.106 & 0.28 & 0.90 & 5.6 & 295.2 & 43.35 \\ 220 & 20 & 20 & 1.053 & 0.067 & 0.18 & 0.94 & 3.6 & 298.8 & 43.72 \\ 240 & 10 & 10 & 1.08 & 0.04 & 0.11 & 0.97 & 1.1 & 299.9 & 43.97\end{array}$




$$
\begin{aligned}
& \text { Appond3x Table 4. Calculation of cumulative amount of } \mathrm{SO}_{2} \text { on wood } \\
& \text { with } 50 \% \mathrm{H}_{2} \mathrm{O} \text { for an influent } \mathrm{SO}_{2} \text {-conc : of 1.12. ppm. }
\end{aligned}
$$

Dry rood used $=6.648$.

Water added $-3.32 \mathrm{ml}$.

Gas flowrate through the adsorber - $11 . /$ min.

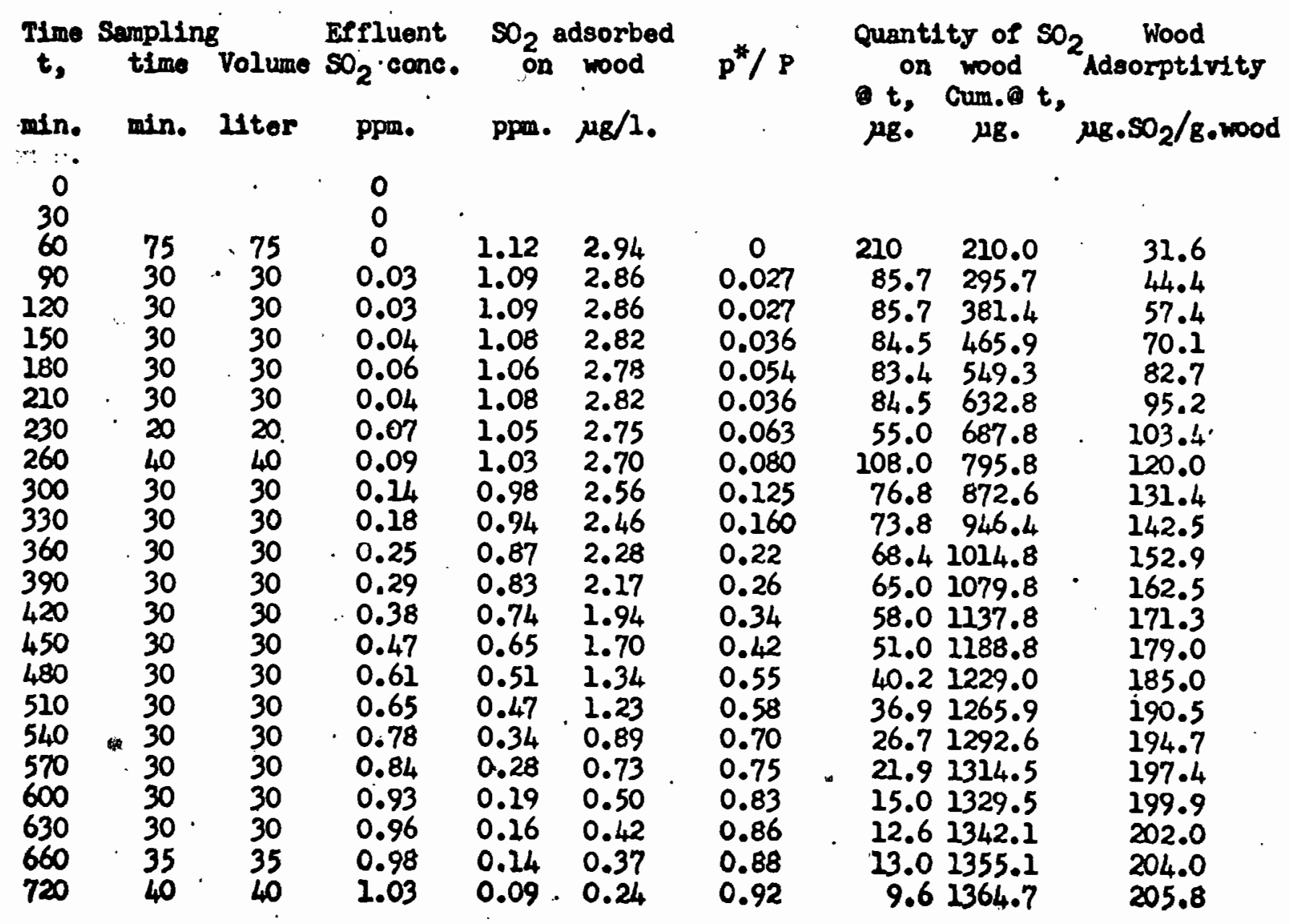


Appendix Table 5. Calculation of cumulative anount of $\mathrm{SO}_{2}$ on wood with seturated $\mathrm{H}_{2} \mathrm{O}$ for influent $\mathrm{SO}_{2}$ cone. of:1.12. ppm.

Dry wood used $=6.0 \mathrm{~g}$.

Water added $=12.50 \mathrm{ml}$.

Gas flowrate through the adsorber $=11 . / \mathrm{min}$.

\begin{tabular}{|c|c|c|c|c|c|c|c|c|c|}
\hline $\begin{array}{l}\text { Time } \\
\text { t, } \\
\text { min. }\end{array}$ & $\begin{array}{l}\text { Sampling } \\
\text { time } \\
\text { min. }\end{array}$ & $\begin{array}{l}\text { Volume } \\
\text { Lter }\end{array}$ & $\begin{array}{c}\text { Effluent } \\
\mathrm{SO}_{2} \text { cone. } \\
\text { ppra. }\end{array}$ & $\begin{array}{l}\mathrm{SO}_{2} \\
\text { on } \\
\text { ppm. }\end{array}$ & $\begin{array}{l}\text { dsorbed } \\
\text { wood } \\
\text { pg/l. }\end{array}$ & $p^{*} / p$ & $\begin{array}{l}\text { Quan } \\
\text { t, } \\
\mu g \text {. }\end{array}$ & $\begin{array}{l}\text { ity of } \mathrm{SO}_{2} \\
\text { wood } \\
\text { Cum. } \mathrm{t}_{\mathrm{g}} \\
\mu \mathrm{g} .\end{array}$ & $\begin{array}{l}\text { Wood } \\
\text { Adsorptivity } \\
\text { } \mu \mathrm{g} \cdot \mathrm{SO}_{2} / \mathrm{g} \cdot \text { wood }\end{array}$ \\
\hline $\begin{array}{r}0 \\
60 \\
90 \\
120 \\
150 \\
180 \\
210 \\
240 \\
270 \\
300 \\
330 \\
360 \\
390 \\
420 \\
450 \\
480 \\
510 \\
540 \\
570 \\
600 \\
660 \\
720 \\
780 \\
840 \\
900 \\
930 \\
960 \\
990 \\
1020 \\
1050 \\
1080\end{array}$ & $\begin{array}{l}80 \\
20 \\
30 \\
30 \\
30 \\
30 \\
30 \\
30 \\
30 \\
30 \\
30 \\
30 \\
30 \\
30 \\
30 \\
30 \\
30 \\
30 \\
60 \\
60 \\
60 \\
60 \\
60 \\
60 \\
30 \\
90 \\
30 \\
30 \\
30 \\
20\end{array}$ & $\begin{array}{l}80 \\
20 \\
30 \\
30 \\
30 \\
30 \\
30 \\
30 \\
30 \\
30 \\
30 \\
30 \\
30 \\
30 \\
30 \\
30 \\
30 \\
30 \\
60 \\
60 \\
60 \\
60 \\
60 \\
60 \\
30 \\
30 \\
30 \\
30 \\
30 \\
20\end{array}$ & $\begin{array}{c}0 \\
0 \\
0.02 \\
0.02 \\
0.03 \\
0.03 \\
0.04 \\
0.05 \\
0.04 \\
0.07 \\
0.06 \\
0.03 \\
0.07 \\
0.14 \\
0.17 \\
0.18 \\
0.28 \\
0.25 \\
0.30 \\
0.32 \\
0.39 \\
0.44 \\
0.56 \\
0.77 \\
0.83 \\
0.86 \\
0.92 \\
0.98 \\
1.02 \\
1.03 \\
1.05\end{array}$ & $\begin{array}{l}1.12 \\
1.10 \\
1.10 \\
1.09 \\
1.09 \\
1.08 \\
1.07 \\
1.08 \\
1.05 \\
1.06 \\
1.09 \\
1.05 \\
0.98 . \\
0.95 \\
0.94 \\
0.84 \\
0.87 \\
0.82 \\
0.80 \\
0.73 \\
0.68 \\
0.56 \\
0.35 \\
0.29 \\
0.26 \\
0.20 \\
0.14 \\
0.10 \\
0.09 \\
0.07\end{array}$ & $\begin{array}{l}2.94 \\
2.88 \\
2.88 \\
2.86 \\
2.86 \\
2.82 \\
2.80 \\
2.82 \\
2.75 \\
2.78 \\
2.86 \\
2.75 \\
2.56 \\
2.49 \\
2.46 \\
2.20 \\
2.28 \\
2.15 \\
2.10 \\
1.91 \\
1.78 \\
1.47 \\
0.92 \\
0.76 \\
0.68 \\
0.52 \\
0.37 \\
0.26 \\
0.24 \\
0.18\end{array}$ & $\begin{array}{c}0 \\
0.018 \\
0.018 \\
0.027 \\
0.027 \\
0.036 \\
0.045 \\
0.036 \\
0.063 \\
0.054 \\
0.027 \\
0.063 \\
.0 .125 \\
0.152 \\
0.160 \\
0.250 \\
0.220 \\
0.268 \\
0.294 \\
0.347 \\
0.392 \\
0.50 \\
0.69 \\
0.74 \\
0.77 \\
0.82 \\
0.87 \\
0.91 \\
0.92 \\
0.94\end{array}$ & $\begin{array}{r}236.2 \\
57.5 \\
86.4 \\
85.6 \\
85.6 \\
84.6 \\
84.0 \\
84.6 \\
82.5 \\
83.4 \\
85.6 \\
82.5 \\
71.9 \\
74.7 \\
73.9 \\
66.0 \\
68.5 \\
64.5 \\
126.0 \\
114.6 \\
108.8 \\
30.0 \\
41.4 \\
44.4 \\
20.2 \\
15.6 \\
11.1 \\
7.8 \\
7.2 \\
5.4\end{array}$ & $\begin{array}{r}236.2 \\
293.7 \\
380.1 \\
465.7 \\
551.3 \\
635.9 \\
719.9 \\
804.5 \\
887.0 \\
970.4 \\
1056.0 \\
1138.5 \\
1210.4 \\
1285.1 \\
2359.0 \\
1425.0 \\
1493.5 \\
1558.0 \\
1684.0 \\
1798.6 \\
1907.4 \\
1937.4 \\
1978.8 \\
2033.2 \\
2043.4 \\
2059.0 \\
2070.1 \\
2077.9 \\
2085.1 \\
2090.5\end{array}$ & $\begin{array}{r}39.33 \\
48.87 \\
63.42 \\
75.59 \\
91.83 \\
106.43 \\
119.74 \\
133.96 \\
147.59 \\
163.04 \\
176.28 \\
189.54 \\
201.84 \\
214.37 \\
226.05 \\
237.81 \\
248.17 \\
259.74 \\
280.08 \\
299.53 \\
317.85 \\
322.10 \\
329.74 \\
337.05 \\
340.08 \\
342.47 \\
345.63 \\
345.89 \\
347.29 \\
348.00\end{array}$ \\
\hline
\end{tabular}


Appendix Table 6. Calculation of cumulative amount of $\mathrm{SO}_{2}$ on dry wood for an Influent $\mathrm{SO}_{2}$ concentration of $1.83 \mathrm{ppm}$.

Dry wood used $=6.15 \mathrm{~g}$.

Water added = None.

Gas flowrate through the adsorber = I liter $/ \mathrm{min}$.

\begin{tabular}{|c|c|c|c|c|c|c|c|c|c|}
\hline $\begin{array}{c}\text { Time } \\
t\end{array}$ & $\begin{array}{l}\text { Samp- } \\
\text { Iing } \\
\text { time }\end{array}$ & Vol; & $\begin{array}{l}\text { Effl. } \\
\mathrm{SO}_{2} \\
\text { conc. }\end{array}$ & $\begin{array}{c}\mathrm{SO}_{2} \text { ad } \\
\text { on }\end{array}$ & $\begin{array}{l}\text { lsorbed } \\
\text { wood }\end{array}$ & $p^{*} / P$ & $\begin{array}{c}\text { Quantity } \\
\text { on } \\
\text { Q t, }\end{array}$ & $\begin{array}{l}\text { y of so, } \\
\text { wood } \\
\text { Cum.ot, }\end{array}$ & $\begin{array}{l}\text { Wood } \\
\text { Adsorptivity }\end{array}$ \\
\hline $\min$. & $\min$. & 1. & ppm. & ppm. & $\mu g / 1$. & & $\mu \mathrm{g}$. & pg. & $\mathrm{g} \cdot \mathrm{SO}_{2} / \mathrm{g} \cdot$ wood \\
\hline $\begin{array}{l}0 \\
0.5 \\
1 \\
2 \\
3 \\
4 \\
5 \\
6 \\
7 \\
8\end{array}$ & $\begin{array}{l}0.25 \\
0.5 \\
1 \\
1 \\
1 \\
1 \\
1 \\
1 \\
1 \\
1\end{array}$ & $\begin{array}{l}0.625 \\
1.25 \\
2.5 \\
2.5 \\
2.5 \\
2.5 \\
2.5 \\
2.5 \\
2.5 \\
2.5\end{array}$ & $\begin{array}{l}0.756 \\
1.305 \\
1.62 \\
1.67 \\
1.72 \\
1.725 \\
1.78 \\
1.82 \\
1.825 \\
1.83\end{array}$ & $\begin{array}{l}1.074 \\
0.525 \\
0.21 \\
0.16 \\
0.17 \\
0.105 \\
0.05 \\
0.01 \\
0.005 \\
0\end{array}$ & $\begin{array}{l}2.82 \\
1.375 \\
0.550 \\
0.418 \\
0.288 \\
0.275 \\
0.131 \\
0.026 \\
0.013 \\
0\end{array}$ & $\begin{array}{l}0.413 \\
0.713 \\
0.885 \\
0.912 \\
0.939 \\
0.9442 \\
0.972 \\
0.094 \\
0.997 \\
1.00\end{array}$ & $\begin{array}{c}1.762 \\
1.719 \\
1.375 \\
1.045 \\
0.720 \\
0.688 \\
0.328 \\
0.065 \\
0.032 \\
0\end{array}$ & $\begin{array}{l}1.762 \\
3.461 \\
4.856 \\
5.901 \\
6.621 \\
7.309 \\
7.637 \\
7.702 \\
7.734 \\
7.734\end{array}$ & $\begin{array}{l}0.29 \\
0.57 \\
0.79 \\
0.96 \\
1.08 \\
1.19 \\
1.24 \\
1.25 \\
1.26 \\
1.26\end{array}$ \\
\hline
\end{tabular}


Appendix Table 7. Calculation of cumulative amount of $\mathrm{SO}_{2}$ on Wood with $116 \mathrm{H}_{2} \mathrm{O}$. for an influent $\mathrm{SO}_{2}$ concentration of 1.83 ppm.

Dry wood used $=6.83 \mathrm{~g}$.

Water added $=0.75 \mathrm{ml}$.

Gas flowrate, through the adsorber $=2.5$ liter/min.

\begin{tabular}{|c|c|c|c|c|c|c|c|c|c|}
\hline $\begin{array}{l}\sin \theta \\
t\end{array}$ & $\begin{array}{l}\text { Sampl } \\
\text { Iing } \\
\text { time }\end{array}$ & Vol. & $\begin{array}{c}\text { Effl. } \\
\mathrm{SO}_{2} \\
\text { conc. }\end{array}$ & $\begin{array}{l}\mathrm{SO}_{2} \\
\text { on }\end{array}$ & $\begin{array}{l}\text { srbed } \\
\text { sod }\end{array}$ & $n^{*} / p$ & $\begin{array}{r}\text { Quant } \\
\text { on } \\
t \text {, }\end{array}$ & $\begin{array}{l}\text { of } s \\
\text { od } \\
\text { um. (a) }\end{array}$ & 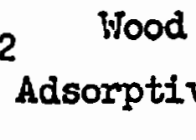 \\
\hline n & min. & 1. & ppm. & ppm. & & & & & \\
\hline $\begin{array}{l}0 \\
1\end{array}$ & $\begin{array}{l}1 \\
1 \\
2 \\
3 \\
2 \\
2 \\
1 \\
1 \\
1 \\
1 \\
1\end{array}$ & $\begin{array}{l}2.5 \\
2.5 \\
5.0 \\
7.5 \\
5.0 \\
5.0 \\
2.5 \\
2.5 \\
2.5 \\
2.5 \\
2.5\end{array}$ & $\begin{array}{l}0.33 \\
0.47 \\
0.65 \\
0.89 \\
1.22 \\
1.57 \\
1.68 \\
1.75 \\
1.78 \\
1.81 \\
1.83\end{array}$ & $\begin{array}{c}1.50 \\
1.36 \\
1.18 \\
0.94 \\
0.61 \\
0.26 \\
0.15 \\
0.08 \\
0.05 \\
0.02 \\
0\end{array}$ & $\begin{array}{c}3.93 \\
3.30 \\
3.09 \\
2.46 \\
1.60 \\
0.68 \\
0.39 \\
0.21 \\
0.131 \\
0.053 \\
0\end{array}$ & $\begin{array}{l}0.180 \\
0.257 \\
0.356 \\
0.487 \\
0.667 \\
0.858 \\
0.018 \\
0.957 \\
0.973 \\
0.990 \\
1.0\end{array}$ & $\begin{array}{r}9.83 \\
0.25 \\
15.45 \\
18.46 \\
8.00 \\
3.40 \\
0.98 \\
0.53 \\
0.33 \\
0.03\end{array}$ & $\begin{array}{r}9.83 \\
18.08 \\
33.53 \\
51.99 \\
59.99 \\
63.39 \\
64.37 \\
64.90 \\
65.23 \\
65.26 \\
65.26\end{array}$ & 4 \\
\hline
\end{tabular}



Appendix Table 8. Calculation of cumulative amount of $\mathrm{SO}_{2}$ on Hood with $20 \% \mathrm{H}_{2} \mathrm{O}$ for an influent $\mathrm{SO}_{2}$ concentration of $1.83 \mathrm{ppm}$.

Dry wood used $=5.85 \mathrm{~g}$.

Water added $=1.27 \mathrm{ml}$.

das flowrate through the adsorber $=2.5 \mathrm{it}$ ter/min:

\begin{tabular}{|c|c|c|c|c|c|c|c|c|c|}
\hline $\begin{array}{l}14 \pi \\
t\end{array}$ & $\begin{array}{l}\text { Samp- } \\
\text { ling } \\
\text { time }\end{array}$ & Vol. & $\begin{array}{c}\text { Effl. } \\
\mathrm{SO}_{2} \\
\text { conc. }\end{array}$ & $\begin{array}{l}\mathrm{SO}_{2} \mathrm{ac} \\
\text { on }\end{array}$ & sorbed & $p^{*} / P$ & $\begin{array}{l}\text { Quant: } \\
\text { on } \\
\text { (a) }\end{array}$ & $\begin{array}{l}\text { ity of so, } \\
\text { wood } \\
\text { Cum. \&t, }\end{array}$ & $\begin{array}{l}\text { Hood } \\
\text { orptivit }\end{array}$ \\
\hline $\min$ & min. & 1. & ppm. & ppm. & $\mu \mathrm{g} / \mathrm{l}$ & & $\mu g$. & $\mu \mathrm{g}$. & \\
\hline $\begin{array}{l}0 \\
1 \\
2 \\
4 \\
5 \\
10 \\
12 \\
13 \\
14 \\
15 \\
16\end{array}$ & $\begin{array}{c}0.5 \\
1 \\
2 \\
1 \\
4 \\
3 \\
1 \\
1 \\
1 \\
1 \\
2 \\
1\end{array}$ & $\begin{array}{c}1.25 \\
2.5 \\
5.0 \\
2.5 \\
10.0 \\
7.5 . \\
2.5 \\
2.5 \\
2.5 \\
2.5 \\
5.0 \\
2.5\end{array}$ & $\begin{array}{l}0.28 \\
0.28 \\
0.28 \\
0.116 \\
0.50 \\
0.87 \\
1.15 \\
1.38 \\
1.61 \\
1.81 \\
1.82 \\
1.83\end{array}$ & $\begin{array}{l}1.55 \\
1.55 \\
1.55 \\
1.37 \\
1.33 \\
0.96 \\
0.68 \\
0.45 \\
0.22 \\
0.02 \\
0.01 \\
0\end{array}$ & $\begin{array}{c}4.061 \\
4.061 \\
4.061 \\
3.589 \\
3.465 \\
2.510 \\
1.732 \\
1.179 \\
0.576 \\
0.053 \\
0.026 \\
0\end{array}$ & $\begin{array}{l}0.153 \\
0.153 \\
0.153 \\
0.251 \\
0.273 \\
0.475 \\
0.628 \\
0.755 \\
0.880 \\
0.990 \\
0.991 \\
1.0\end{array}$ & $\begin{array}{r}5.07 \\
10.14 \\
20.28 \\
8.97 \\
34.05 \\
13.82 \\
4.46 \\
2.95 \\
1.44 \\
0.13 \\
0.13 \\
0\end{array}$ & $\begin{array}{r}5.07 \\
15.21 \\
35.49 \\
44.46 \\
79.31 \\
98.13 \\
102.59 \\
105.54 \\
106.98 \\
107.11 \\
107.24 \\
107.24\end{array}$ & $\begin{array}{r}0.87- \\
2.59 \\
6.07 \\
7.51 \\
13.54 \\
16.79 \\
17.65 \\
18.14 \\
18.26 \\
18.30 \\
18.35 \\
18.35\end{array}$ \\
\hline
\end{tabular}


Appendix Table 9. Calculation of cumulative amount of $\mathrm{SO}_{2}$ on wood with $5 \mathrm{CF} \mathrm{H}_{2} \mathrm{O}$ for an influent $\mathrm{SO}_{2}$ concentration of $1.83 \mathrm{ppm}$.

Dry wood used $=6.72 \mathrm{~g}$.

Water added $=3.36 \mathrm{ml}$.

Gas flowrate through the adsorber $=2.5$ liter/min.

$\operatorname{Time}$

Samp- Effl. $\mathrm{SO}_{2}$ adsorbed

$t$ time

min. min. 1. ppm. ppm。- $\mu \mathrm{g} / \mathrm{l}$.

$\begin{array}{llll}0 & 0.5 & 1.25 & 0.25\end{array}$

$\begin{array}{llll}1 & 2 & 5.0 & 0.28\end{array}$

$\begin{array}{llll}2 & 3 & 7.5 & 0.36\end{array}$

$\begin{array}{llll}3 & 3 & 7.5 & 0.53\end{array}$

$\begin{array}{llll}5 & 3 & 7.5 & 0.75\end{array}$

$\begin{array}{llll}10 & 2 & 5.0 & 0.88\end{array}$

$\begin{array}{llll}12 & 2 & 5.0 & 1.24\end{array}$

$15: 4 \quad 10.0 \quad 1.40$

$\begin{array}{llll}18 & 2 & 5.0 & 1.56\end{array}$

$\begin{array}{llll}20 & 2 & 5.0 & 1.61\end{array}$

$\begin{array}{llll}22 & 3 & 7.5 & 1.72\end{array}$

$\begin{array}{llll}25 & 4 & 10.0 & 1.77\end{array}$

$\begin{array}{llll}30 & 4 & 10.0 & 1.82\end{array}$

$\begin{array}{llll}35 & 2 & 5.0 & 1.83\end{array}$

1.58

1.55

$1.47 \quad 3.92$

1.30

1.08

0.95

0.59

0.43

0.27

0.22

0.11

0.05

0.01

0
3.40

2.84

2.48

$1.51_{t}$

1.13

0.72

0.58

0.290 .940

$\begin{array}{ll}0.13 & 0.966 \\ 0.03 & 0.995\end{array}$

$\begin{array}{cl}0.03 & 0.995 \\ 0 & 1.0\end{array}$
Quantity of $\mathrm{SO}_{2}$

on wood Wood

a. $t$, Cum. ot, Adsorptivity

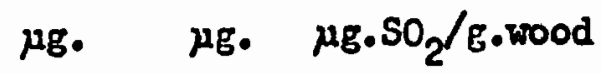

$$
5.18
$$

5.78

0.77

20.30

29.40

25.50

21.22

12.40

7.70

11.30

3.55

2.90

2.18

1.30

0.30

143.23

243.23

3.79

$54.88 \quad 8.17$

$80.38 \quad 11.95$

$101.60 \quad 15.27$

$114.00 \quad 17.96$

$121.70 \quad 10.10$

$133.00 \quad 19.80$

$136.55 \quad 20.30$

$139.45 \quad 20.79$

2111.6321 .08

21.26

21.35

21.35 
Appendix Table 10. Calculation of cumulative amount of $\mathrm{SO}_{2}$ on wood $\cdots:$ with saturated molsture content for influent $\mathrm{SO}_{2}$ concentration of $.1 .83 \mathrm{ppm}$.

Dry rood used $=.7 .0 \mathrm{~B}$.

Water Added $=14.0 \mathrm{ml}$.

Gas flowrate through the adsorber $=2.5 \mathrm{l} / \mathrm{min}$.

Time Sempling Effluent $\mathrm{SO}_{2}$ adsorbed

$t$, time Volume $\mathrm{SO}_{2}$ conc. $\mathrm{on}^{\mathrm{wood}} \mathrm{p} / \mathrm{P}$ min. min. Iter ppm. ppm. $\mu g / l$.

$\begin{array}{rccccccccc}0 & 2.5 & 6.25 & 0.20 & 1.63 & 4.27 & 0.109 & 26.70 & 26.70 & 3.79 \\ 5 & 5 & 12.50 & 0.31 & 1.52 & 3.98 & 0.169 & 49.80 & 76.50 & 10.84 \\ 10 & 5 & 12.50 & 0.41 & 1.42 & 3.72 & 0.224 & 46.50 & 123.00 & 17.58 \\ 15 & 5 & 12.50 & 0.54 & 1.29 & 3.38 & 0.295 & 42.30 & 165.30 & 23.60 \\ 20 & 10 & 25.00 & 0.79 & 1.04 & 2.72 & 0.432 & 68.00 & 233.30 & 33.24 \\ 30 & 10 & 25.00 & 1.03 & 0.80 & 2.10 & 0.563 & 52.50 & 285.80 & 40.85 \\ 140 & 10 & 25.00 & 1.09 & 0.74 & 1.94 & 0.595 & 48.40 & 334.20 & 47.78 \\ 55 & 15 & 37.50 & 1.15 & 0.68 & 1.78 & 0.628 & 66.80 & 401.00 & 57.25 \\ 60 & 15 & 37.50 & 1.26 & 0.57 & 1.49 & 0.688 & 55.80 & 456.80 & 65.00 \\ 75 & 15 & 37.50 & 1.33 & 0.50 & 1.31 & 0.727 & 49.20 & 506.00 & 72.23 \\ 90 & 15 & 37.50 & 1.39 & 0.44 & 1.15 & 0.760 & 43.10 & 549.10 & 78.52 \\ 105 & 15 & 37.50 & 1.46 & 0.37 & 0.97 & 0.798 & 36.40 & 585.50 & 83.50 \\ 120 & 15 & 37.50 & 1.52 & 0.31 & 0.81 & 0.830 & 30.40 & 615.90 & 88.07 \\ 135 & 15 & 37.50 & 1.57 & 0.26 & 0.68 & 0.857 & 25.50 & 641.40 & 91.48 \\ 150 & 10 & 25.00 & 1.57 & 0.26 & 0.68 & 0.857 & 17.00 & 658.40 & 93.97 \\ 160 & 5 & 12.50 & 1.57 & 0.26 & 0.68 & 0.857 & 8.50 & 666.90 & 95.21 \\ 165 & 15 & 37.50 & 1.60 & 0.23 & 0.60 & 0.874 & 22.50 & 689.40 & 98.36 \\ 180 & 10 & 25.00 & 1.60 & 0.23 & 0.60 & 0.874 & 15.00 & 704.40 & 100.25 \\ 190 & 10 & 25.00 & 1.62 & 0.21 & 0.55 & 0.885 & 13.75 & 718.15 & 102.38 \\ 200 & 10 & 25.00 & 1.70 & 0.13 & 0.34 & 0.928 & 8.50 & 726.65 & 103.74 \\ 210 & 10 & 25.00 & 1.73 . & 0.10 & 0.26 & 0.945 & 6.50 & 733.15 & 104.82 \\ 240 & 30 & 75.00 & 1.79 & 0.04 & 0.11 & 0.978 & 18.25 & 741.40 & 106.03 \\ 300 & 50 & 125.00 & 1.82 & 0.01 & 0.03 & 0.995 & 3.75 & 745.15 & 106.38\end{array}$

Quantity of $\mathrm{SO}_{2}$ Wood
on wood Adsorptivity a $t$, Gurn. $t$, $\mu g$. $\mu g$. $\mu 8 \cdot \mathrm{SO}_{2} / \mathrm{g} \cdot \operatorname{mood}$ 
Appendix Table 11. Calculation of cumlative amount of $\mathrm{SO}_{\text {, }}$ on dry wood for the influent $\mathrm{SO}_{2}$ conc. of 4.66 ppm.

Dry wood used $=6.40 \mathrm{~g}$.

Flowrate of Gas through the adsorber $=2.51 . / m i n$.

\begin{tabular}{|c|c|c|c|c|c|c|c|c|c|}
\hline tym & $\begin{array}{l}\text { Samp- } \\
\text { ling } \\
\text { time }\end{array}$ & Vol. & $\begin{array}{c}\text { Effl. } \\
\mathrm{SO}_{2} \\
\text { conc. }\end{array}$ & $\begin{array}{l}\mathrm{SO}_{2} \\
\text { on }\end{array}$ & ש00 & $p^{*}$ & $\begin{array}{l}\text { Quant } \\
\text { on } \\
t \text {, }\end{array}$ & $\begin{array}{l}\text { by of } \mathrm{SO}_{2} \\
\text { wood } \\
\text { Cum. }\end{array}$ & divity \\
\hline min. & min. & 7 & m. & ppm. & & & $\mu_{\mathrm{g}}$ & & \\
\hline $\begin{array}{l}0 \\
0.5 \\
0.75 \\
1 \\
1.5 \\
2 \\
2.5 \\
3 \\
4 \\
5 \\
6 \\
7 \\
8 \\
9\end{array}$ & $\begin{array}{l}0.5 \\
0.5 \\
0.5 \\
0.5 \\
0.5 \\
0.5 \\
0.5 \\
0.5 \\
.1 \\
1 \\
1 \\
.1 \\
1\end{array}$ & $\begin{array}{l}1.25 \\
1.25 \\
1.25 \\
1.25 \\
1.25 \\
1.25 \\
1.25 \\
1.25 \\
2.5 \\
2.5 \\
2.5 \\
2.5 \\
2.5 \\
2.5\end{array}$ & $\begin{array}{l}2.85 \\
3.96 \\
4.20 \\
4.36 \\
4.36 \\
4.44 \\
4.44 \\
4.47 \\
4.47 \\
4.50 \\
4.50 \\
4.56 \\
4.56 \\
4.60\end{array}$ & $\begin{array}{l}1.75 \\
0.64 \\
0.40 \\
0.24 \\
0.24 \\
0.16 \\
0.16 \\
0.13 \\
0.13 \\
0.10 \\
0.10 \\
0.04 . \\
0.04 . \\
0 .\end{array}$ & $\begin{array}{l}4.60 \\
1.78 \\
1.05 \\
0.63 \\
0.63 \\
0.42 \\
0.42 \\
0.34 \\
0.34 \\
0.26 \\
0.26 \\
0.11 \\
0.17 \\
0.0\end{array}$ & $\begin{array}{l}0.620 \\
0.861 \\
0.913 \\
0.949 \\
0.949 \\
0.966 \\
0.966 \\
0.972 \\
0.972 \\
0.980 \\
0.980 \\
0.991 \\
0.991 \\
1.0\end{array}$ & $\begin{array}{l}5.75 \\
2.23 \\
1.31 \\
0.79 \\
0.79 \\
0.52 \\
0.52 \\
0.43 \\
0.85 \\
0.65 \\
0.65 \\
0.38 \\
0.38\end{array}$ & $\begin{array}{r}5.75 \\
7.98 \\
9.29 \\
10.08 \\
10.87 \\
11.39 \\
11.91 \\
12.34 \\
13.20 \\
13.85 \\
11.50 \\
11.88 \\
15.26 \\
15.26\end{array}$ & $\begin{array}{l}0.90 \\
1.25 \\
1.45 \\
1.56 \\
1.69 \\
1.78 \\
1.83 \\
1.93 \\
2.06 \\
2.17 \\
2.27 \\
2.32 \\
2.38 \\
2.38\end{array}$ \\
\hline
\end{tabular}


Appendix Table 12. Calculation of cumulative amount of $\mathrm{SO}_{2}$ an wood ifth $21 \% \mathrm{H}_{2} \mathrm{O}$ for an influent $\mathrm{SO}_{2}$ conc. of $4.60 \mathrm{ppm}$.

Drg wood used $=6.71 \mathrm{~g}$.
Water added $=0.74 \mathrm{ml}$.
Gas flowrate through the adsorber $=2.5 \mathrm{I} . / \mathrm{min}$.

Time Samp- Vol. $\begin{gathered}\text { Effl. } \\ \mathrm{SO}_{2}\end{gathered} \mathrm{SO}_{2}$ adisorbed wood $\mathrm{p} / \mathrm{P}$

$t$ time. conc.

min. min. 1. ppm. $\mathrm{ppm}, \mu \mathrm{g} / \mathrm{I}$

Quantity of $\mathrm{SO}_{2}$ Hood
on wood

(1) $t$, Cum. : $t$,

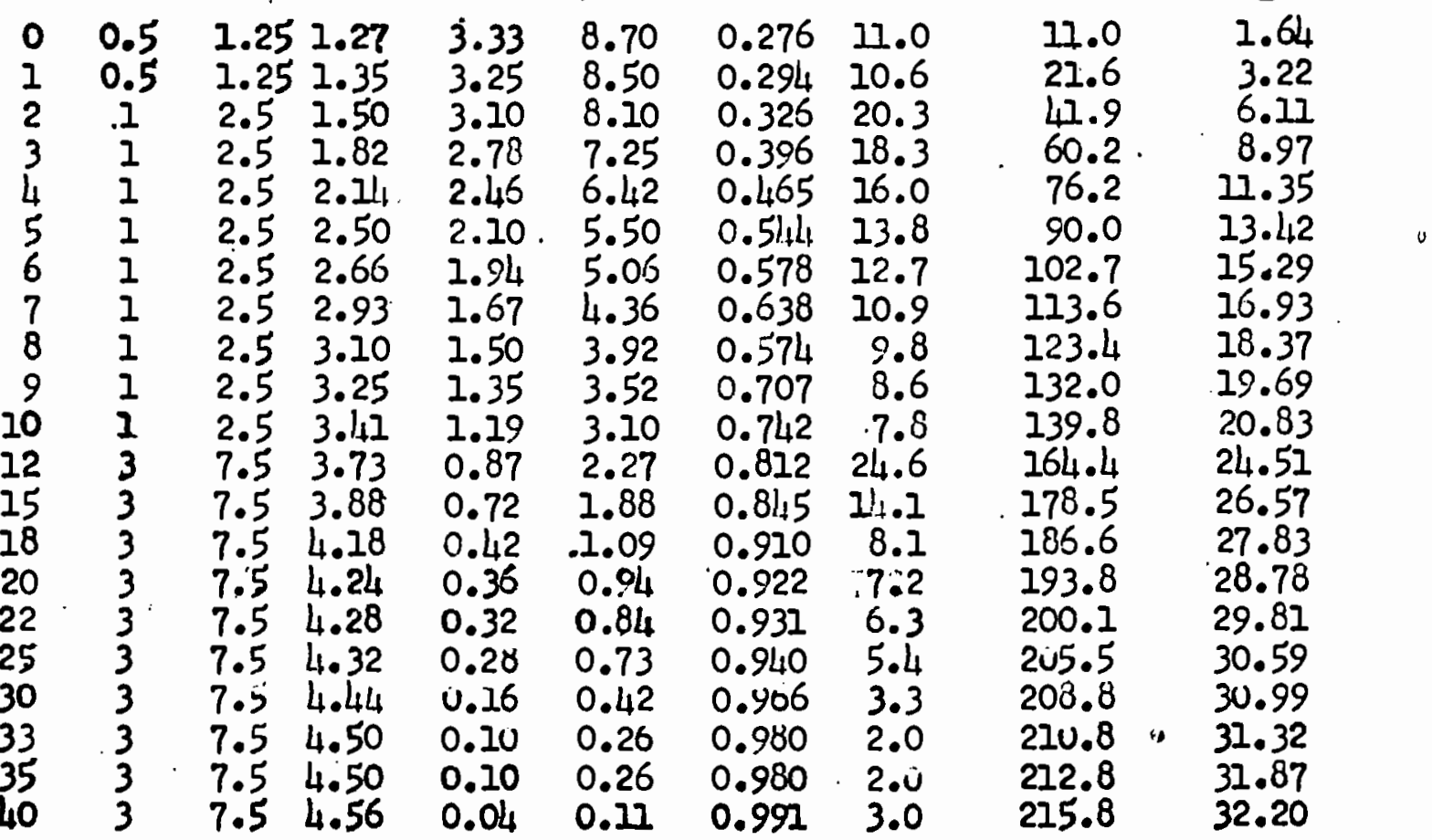


Appendix Table 13. Calculation of cumulative amount of $\mathrm{SO}_{2}$ on wood with $12 \mathrm{sH}_{2} \mathrm{O}$ for the influent $\mathrm{SO}_{2}$ conc. of $4.60 \mathrm{ppm}$.

Dry wood used $=7.16 \mathrm{~g}$.

Water added $=1.44 \mathrm{ml}$.

Gas flowrate through the adsorber $=2.51 . /$ min.

\begin{tabular}{|c|c|c|c|c|c|c|c|c|c|}
\hline $\begin{array}{l}\text { Time } \\
t\end{array}$ & $\begin{array}{l}\text { Samp- } \\
\text { ling } \\
\text { time }\end{array}$ & Tol. & $\begin{array}{l}\mathrm{Effz} \\
\mathrm{SO}_{2} \\
\text { conc. }\end{array}$ & $\begin{array}{l}\mathrm{SO}_{2} \mathrm{ac} \\
\text { on }\end{array}$ & $\begin{array}{l}\text { rbed } \\
\text { od }\end{array}$ & $p^{*} / p$ & \multicolumn{3}{|c|}{$\begin{array}{l}\text { Quantity of } \mathrm{SO}_{2} \text { Wood } \\
\text { on wood } \\
\text { Adsorptiv } \\
t \text {. Cum. ot, }\end{array}$} \\
\hline min. & min. & 1. & ppm. & ppm. & $\mathrm{pg} / \mathrm{I}$ & & $\mu \mathrm{g}$. & $\mu \mathrm{g}$. & so 10 \\
\hline $\begin{array}{r}0 \\
2 \\
5 \\
8 \\
10 \\
12 \\
13 \\
15 \\
18 \\
21 \\
25 \\
30 \\
35 \\
38 \\
42\end{array}$ & $\begin{array}{c}1 \\
2 \\
3 \\
3 \\
2 \\
1 \\
1 \\
2 \\
4 \\
2 \\
4 \\
5 \\
5 \\
4 \\
6 \\
6 \\
4 \\
10 \\
6 . \\
4\end{array}$ & $\begin{array}{c}2.5 \\
5 \\
7.5 \\
7.5 \\
5 \\
2.5 \\
2.5 \\
5 \\
10 \\
5 \\
10 \\
12.5 \\
12.5 \\
10 \\
15 \\
15 \\
10 \\
25 \\
15 \\
10 \\
12.5\end{array}$ & $\begin{array}{l}0.715 \\
0.795 \\
0.910 \\
0.99 \\
1.27 \\
1.59 \\
1.74 \\
2.14 \\
2.38 \\
2.82 \\
3.25 \\
3.89 \\
4.05 \\
4.17 \\
4.24 . \\
4.36 \\
4.40 \\
4.444 \\
4.48 \\
4.52 \\
4.57\end{array}$ & $\begin{array}{l}3.885 \\
3.805 \\
3.69 . \\
3.61 \\
3.33 \\
3.01 \\
2.86 \\
2.46 \\
2.22 \\
1.78 \\
1.35 \\
0.71 \\
0.55 \\
0.43 \\
0.36 \\
0.24 \\
0.40 \\
0.16 \\
0.12 \\
0.08 \\
0.03\end{array}$ & $\begin{array}{l}9.93 \\
9.90 \\
9.65 \\
9.45 \\
8.73 \\
7.90 \\
7.50 \\
6.45 \\
5.82 \\
4.66 \\
3.54 \\
1.86 \\
1.44 \\
1.13 \\
0.94 \\
0.63 \\
0.52 \\
0.42 \\
0.31 \\
0.21 \\
0.08\end{array}$ & $\begin{array}{l}0.155 \\
0.173 \\
0.198 \\
0.215 \\
0.276 \\
0.345 \\
0.377 \\
0.465 \\
0.516 \\
0.613 \\
0.706 \\
0.844 \\
0.880 \\
0.905 \\
0.920 \\
0.946 \\
0.957 \\
0.964 \\
0.973 \\
0.982 \\
0.992\end{array}$ & $\begin{array}{r}24.8 \\
.45 .5 \\
72.3 \\
70.9 \\
47.5 \\
19.8 \\
18.8 \\
32.2 \\
50.2 \\
23.2 \\
35.4 \\
23.2 \\
18.0 \\
11.3 \\
14.2 \\
9.5 \\
5.2 \\
10.5 \\
4.7 \\
2.1 \\
1.0\end{array}$ & $\begin{array}{r}24.8 \\
70.3 \\
112.6 \\
213.5 \\
261.3 \\
280.8 \\
299.6 \\
331.8 \\
390.0 \\
413.2 \\
448.6 \\
471.8 \\
489.8 \\
501.1 \\
513.3 \\
524.8 \\
530.0 \\
540.5 \\
545.2 \\
547.3 \\
548.3\end{array}$ & $\begin{array}{l}80 \\
47 \\
48 \\
92 \\
43 \\
50 \\
53 \\
50 \\
34 \\
15 \\
99 \\
33 \\
16 \\
13\end{array}$ \\
\hline
\end{tabular}


Appendix Table 14. Calculation of cumulative amount of $\mathrm{SO}_{2}$ on wood with $50 \% \mathrm{H}_{2} \mathrm{O}$ for influent $\mathrm{SO}_{2}$ conc. of $4.60^{2} \mathrm{ppm}$.

Dry wood used $=6.93 \mathrm{~g}$.

Water added $=3.47 \mathrm{ml}$.

Gas flowrate through the adsorber $=2.51 . /$ min.

\begin{tabular}{|c|c|c|c|c|c|c|c|c|c|}
\hline TS & $\begin{array}{l}\text { amp- } \\
\text { ing } \\
\text { ime }\end{array}$ & Vol. & $\begin{array}{l}\mathrm{Effl} \\
\mathrm{SO}_{2} \\
\mathrm{conc}^{2}\end{array}$ & $\begin{array}{l}\mathrm{SO}_{2} \text { ac } \\
\text { on } \mathrm{r}\end{array}$ & $\begin{array}{l}\text { orb. } \\
\text { od }\end{array}$ & $p^{*} / p$ & $\begin{array}{c}\text { Quant } \\
\text { on }\end{array}$ & $\begin{array}{l}\text { ty of } \mathrm{SO}_{2} \\
\text { rood }\end{array}$ & $\begin{array}{c}\text { Wood } \\
\text { Adsorptivity }\end{array}$ \\
\hline & n. & 1. & ppm. & ppm. & $\mu g / 1$ & & $\begin{array}{l}\text { @ t, } \\
\mu \mathrm{g} \cdot .\end{array}$ & $\begin{array}{c}\text { Cum. Q } \\
\mu \mathrm{g} .\end{array}$ & $\mathrm{gg} \cdot \mathrm{SO}_{2} / \mathrm{g} \cdot$ wood \\
\hline $\begin{array}{l}0 \\
10 \\
17 \\
20 \\
22 \\
25 \\
30 \\
35 \\
42 \\
48 \\
50 \\
55 \\
58 \\
60 \\
65 \\
70 \\
75 \\
80 \\
85 \\
90\end{array}$ & $\begin{array}{r}1 \\
12 \\
5 \\
2 \\
2 \\
4 \\
4 \\
6 \\
8 \\
4 \\
4 \\
4 \\
2 \\
4 \\
4 \\
6 \\
4 \\
6 \\
4 \\
4 \\
3\end{array}$ & $\begin{array}{l}2.5 \\
30 \\
12.5 \\
.5 \\
5 \\
10 \\
10 \\
15 \\
20 \\
10 \\
10 \\
10 \\
5 \\
10 \\
10 \\
15 \\
10 \\
15 \\
10 \\
10 \\
7.5\end{array}$ & $\begin{array}{l}0.635 \\
0.635 \\
0.675 \\
0.80 \\
0.95 \\
1.15 \\
1.59 \\
2.06 \\
2.62 \\
2.70 \\
2.94 \\
3.41 \\
3.61 \\
3.73 \\
3.89 \\
4.05 \\
4.20 \\
4.30 \\
4.40 \\
4.52 \\
4.56\end{array}$ & $\begin{array}{l}3.965 \\
3.965 \\
3.925 \\
3.80 \\
3.65 \\
3.45 \\
3.01 \\
2.54 \\
1.98 \\
1.90 \\
1.66 \\
1.19 \\
0.99 \\
0.87 \\
0.71 \\
0.55 \\
0.40 \\
0.30 \\
0.20 \\
0.08 \\
0.04\end{array}$ & $\begin{array}{l}10.4 \\
10.4 \\
10.3 \\
10.0 \\
9.65 \\
9.05 \\
7.90 \\
6.65 \\
5.20 \\
4.97 \\
4.35 \\
3.12 \\
2.50 \\
2.28 \\
1.86 \\
1.44 \\
1.05 \\
0.78 \\
0.53 \\
0.21 \\
0.17\end{array}$ & $\begin{array}{l}0.138 \\
0.138 \\
0.147 \\
0.174 \\
0.207 \\
0.250 \\
0.346 \\
0.1448 \\
0.5148 \\
0.587 \\
0.638 \\
0.741 \\
0.784 \\
0.810 \\
0.846 \\
0.880 \\
0.912 \\
0.935 \\
0.956 \\
0.982 \\
0.991\end{array}$ & $\begin{array}{r}26.0 \\
312.0 \\
129.0 \\
50.0 \\
48.3 \\
90.5 \\
79.0 \\
99.5 \\
104.0 \\
49.7 \\
43.5 \\
31.2 \\
13.0 \\
22.8 \\
18.6 \\
21.6 \\
10.5 \\
11.7 \\
5.3 \\
2.1 \\
0.83\end{array}$ & $\begin{array}{r}26.0 \\
338.0 \\
466.0 \\
516.0 \\
564.3 \\
654.8 \\
733.8 \\
833.3 \\
937.3 \\
987.0 \\
1030.5 \\
1061.7 \\
1074.7 \\
1097.5 \\
1116.1 \\
1137.7 \\
1148.2 \\
1159.9 \\
1165.2 \\
1167.3 \\
1168.13\end{array}$ & $\begin{array}{r}3.75 \\
48.78 \\
67.05 \\
74.46 \\
78.72 \\
94.34 \\
105.48 \\
120.04 \\
135.07 \\
112.25 \\
148.37 \\
153.07 \\
154.84 \\
158.18 \\
160.07 \\
164.10 \\
165.47 \\
167.43 \\
168.12 \\
168.43 \\
168.56\end{array}$ \\
\hline
\end{tabular}


Appendix Table 15. Calculation of cumulative amount of $\mathrm{SO}_{2}$ on wood with saturated moisture content for an influent $\mathrm{SO}_{2}$ conc. of .4 .60 ppm.

Dry wood used $=6.89 \mathrm{~g}$.

Water added $=13.8 \mathrm{ml}$.

Gas flowrate through the adsorber $=2.5 \mathrm{I} / \mathrm{min}$ :

\begin{tabular}{|c|c|c|c|c|c|c|c|c|c|}
\hline $\begin{array}{l}\text { Time } \\
t\end{array}$ & $\begin{array}{l}\text { Samp- } \\
\text { ling } \\
\text { time }\end{array}$ & Vol. & $\begin{array}{l}\text { Effl. } \\
\mathrm{SO}_{2} \\
\text { cone. }\end{array}$ & $\begin{array}{c}\mathrm{SO}_{2} \\
\text { on }\end{array}$ & $\begin{array}{l}\text { orbed } \\
\text { ood }\end{array}$ & $p^{*} / p$ & $\begin{array}{l}\text { Quant } \\
\text { on } \\
\text { (a) } t \text {, }\end{array}$ & $\begin{array}{l}\text { ty of } \mathrm{SO}_{2} \\
\text { rood } \\
\text { cum. @ } t,\end{array}$ & $\begin{array}{l}\text { Wood } \\
\text { Idsorptivity }\end{array}$ \\
\hline in & min & 1. & $\mathrm{~m}_{\mathrm{l}}$ & ppm. & 1 & & $\mu \mathrm{g}$ & & \\
\hline $\begin{array}{l}0 \\
5 \\
7.5 \\
10 \\
15 \\
20 \\
25 \\
30 \\
35 \\
40 \\
50 \\
60 \\
65 \\
70 \\
80 \\
90 \\
95\end{array}$ & $\begin{array}{l}1 \\
5 \\
3 \\
4 \\
4 \\
6 \\
4 \\
6 \\
4 \\
10 \\
10 \\
6 \\
4 \\
10 \\
10 \\
6 \\
4 \\
10 \\
10 \\
6 \\
2\end{array}$ & $\begin{array}{l}2.5 \\
12.5 \\
7.5 \\
10 \\
10 \\
15 \\
10 \\
15 \\
10 \\
25 \\
25 \\
15 \\
10 \\
25 \\
25 \\
15 \\
10 \\
25 \\
25 \\
15 \\
5\end{array}$ & $\begin{array}{l}0.445 \\
0.445 \\
0.595 \\
0.754 \\
1.19 \\
1.43 \\
1.82 \\
2.10 \\
2.30 \\
2.50 \\
2.65 \\
2.85 \\
3.17 \\
3.37 \\
3.42 \\
3.50 \\
3.60 \\
3.90 \\
4.44 \\
4.52 \\
4.56\end{array}$ & $\begin{array}{l}4.155 \\
4.155 \\
4.005 \\
3.846 \\
3.41 \\
3.17 \\
2.78 \\
2.50 \\
2.30 \\
2.10 \\
1.95 \\
1.75 \\
1.43 \\
1.23 \\
1.18 \\
1.10 \\
1.00 \\
0.70 \\
0.16 \\
0.08 \\
0.04\end{array}$ & $\begin{array}{l}10.9 \\
10.9 \\
10.5 \\
10.1 \\
8.94 \\
8.30 \\
7.29 \\
6.55 \\
6.02 \\
5.50 \\
5.10 \\
4.58 \\
3.74 \\
3.22 \\
3.09 \\
2.88 \\
2.62 \\
1.83 \\
0.41 \\
0.20 \\
0.20\end{array}$ & $\begin{array}{l}0.097 \\
0.097 \\
0.129 \\
0.164 \\
0.258 \\
0.317 \\
0.396 \\
0.456 \\
0.500 \\
0.543 \\
0.576 \\
0.620 \\
0.689 \\
0.732 \\
0.743 \\
0.761 \\
0.793 \\
0.847 \\
0.965 \\
0.982 \\
0.991\end{array}$ & $\begin{array}{r}27.2 \\
136.1 \\
78.8 \\
101.0 \\
89.4 \\
121.5 \\
72.9 \\
98.4 \\
60.2 \\
137.5 \\
127.5 \\
68.6 \\
37.4 \\
80.5 \\
77.3 \\
43.2 \\
26.2 \\
45.7 \\
10.3 \\
3.0 \\
0.5\end{array}$ & $\begin{array}{r}27.2 \\
163.3 . \\
242.1 \\
3143.1 \\
432.5 \\
557.0 \\
629.9 \\
728.3 \\
788.5 \\
926.0 \\
1053.5 \\
1122.1 \\
1159.5 \\
1240.0 \\
1317.3 \\
1360.5 \\
1386.7 \\
1432.4 \\
1442.7 \\
1445.7 \\
1446.2\end{array}$ & $\begin{array}{r}3.94 \\
23.64 \\
35.05 \\
49.76 \\
62.43 \\
80.69 \\
91.32 \\
105.41 \\
114.28 \\
134.37 \\
152.78 \\
162.51 \\
168.05 \\
179.95 \\
190.82 \\
197.35 \\
200.17 \\
207.46 \\
209.14 \\
209.43 \\
209.56\end{array}$ \\
\hline
\end{tabular}

